LBL -32275

DE93 001594

\title{
AN OVERVIEW OF ENERGY SUPPLY AND DEMAND
}

IN CHINA

May 1992

FENG LIU

WILLIAM B. DAVIS

MARK D. LEVINE

ENERGY ANALYSIS PROGRAM

ENERGY \& ENVIRONMENT DIVISION LAWRENCE BERKELEY LABORATORY

This work was funded by the Deputy Undersecretary of the Office of Policy, Planning, and Analysis of the U.S. Department of Energy under Contract No. DE-AC03-76SF00098. 
Part I: Energy Resources

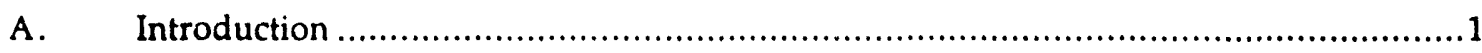

B. Energy Endowments

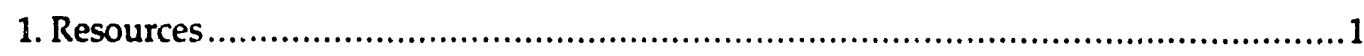

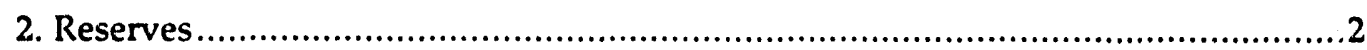

C. Coal

1. Coal resource and reserve estimates.........................................................

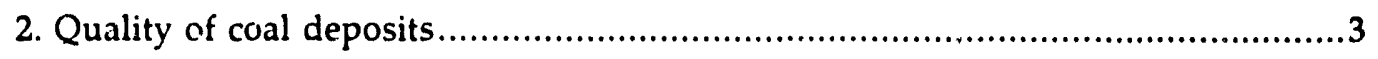

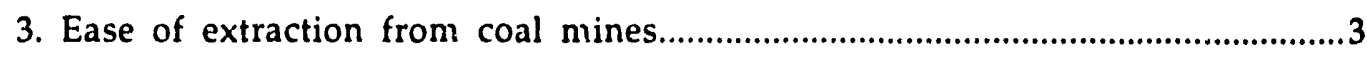

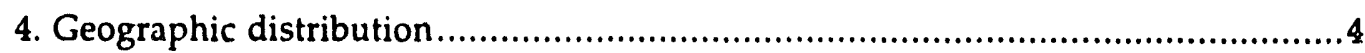

D. Crude Oil

1. Resource and reserve estimates............................................................4

2. Quality of crude oil deposits .....................................................................

3. Geographic distribution of crude oil deposits ................................................5

E. Natural Gas

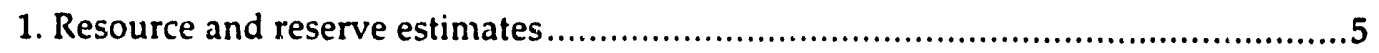

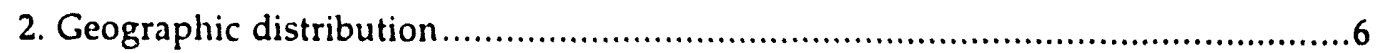

F. Hydropower

1. Hydropower resource estimates ..............................................................6

2. Size distribution of hydropower sites ...................................................6

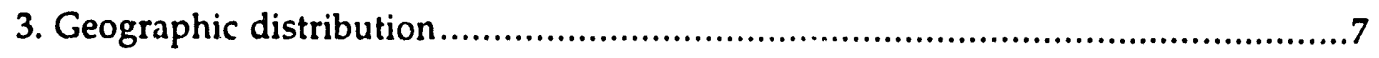

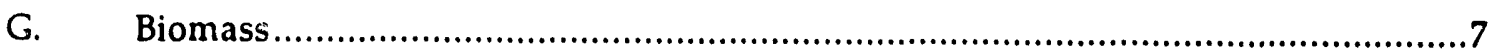

H. Other Energy Resources

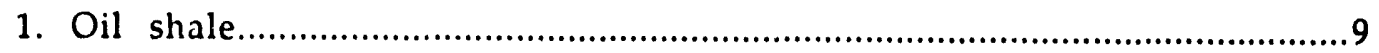

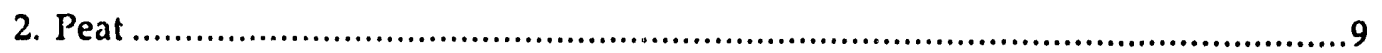

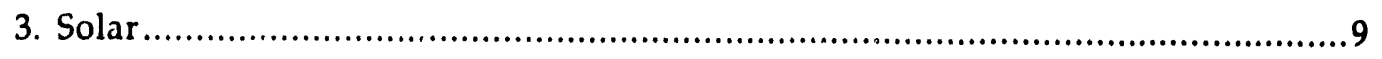

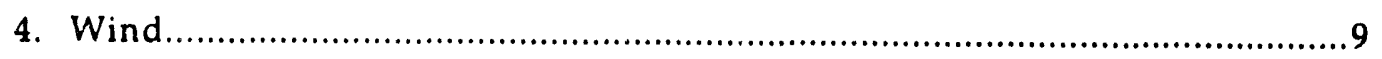

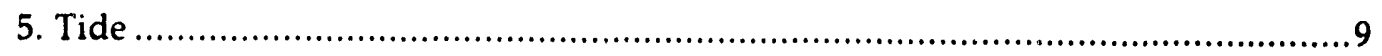

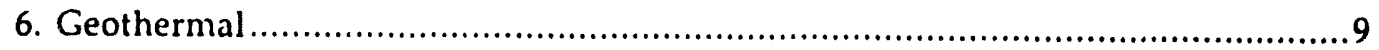

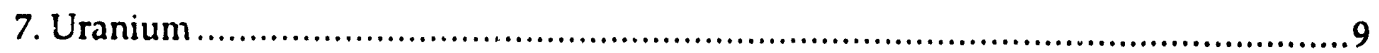

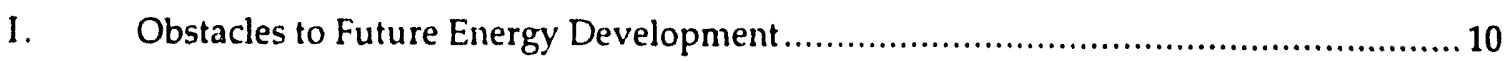

Part II: Energy Supply

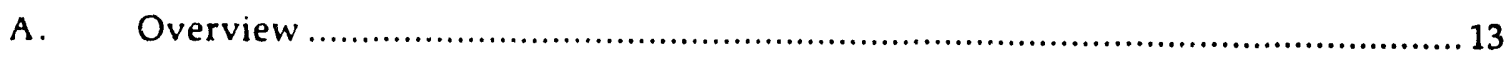

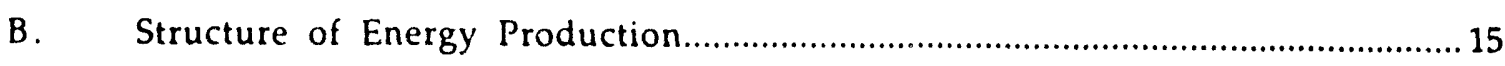




\section{TABLE OF CONTENTS}

C. Energy Imports and Exports

D. Coal Supply

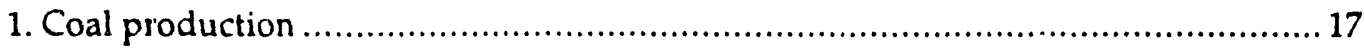

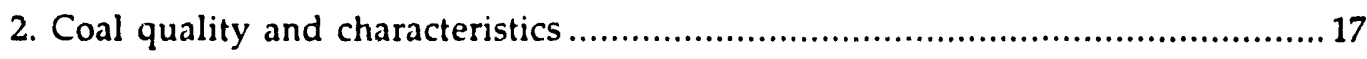

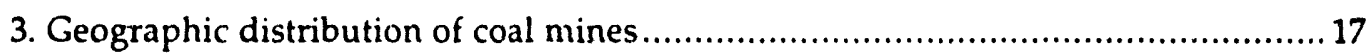

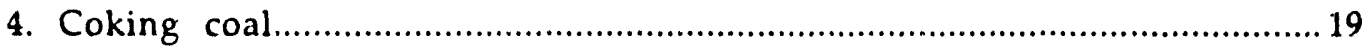

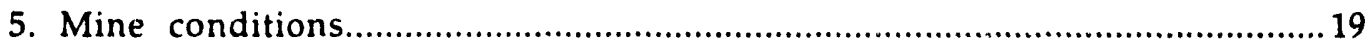

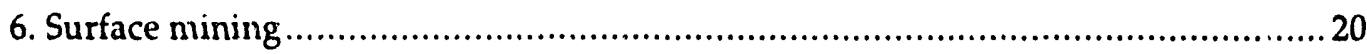

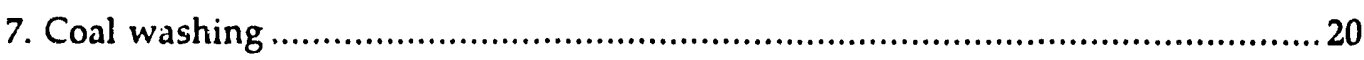

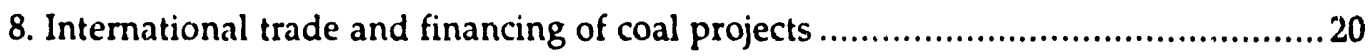

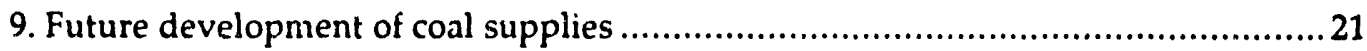

E. Petroleun Supply

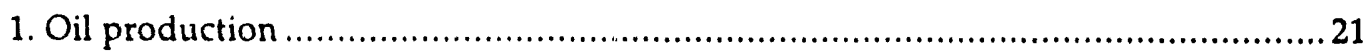

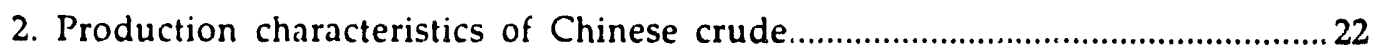

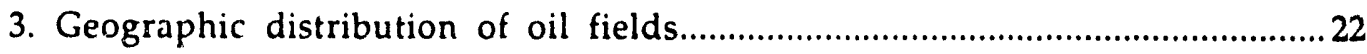

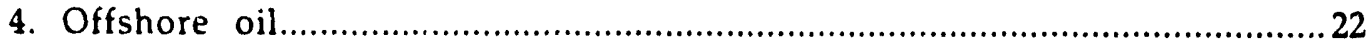

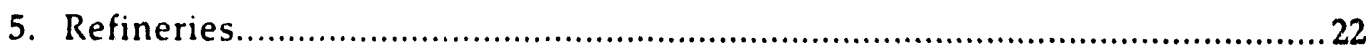

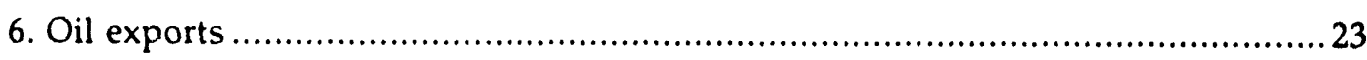

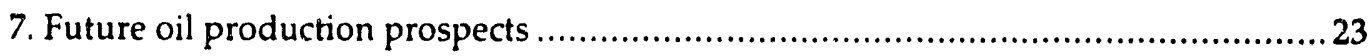

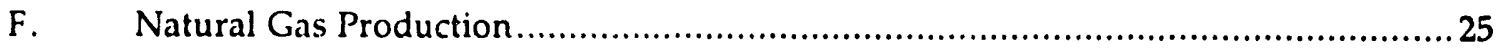

G. Electricity Supply

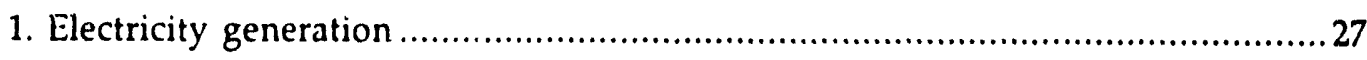

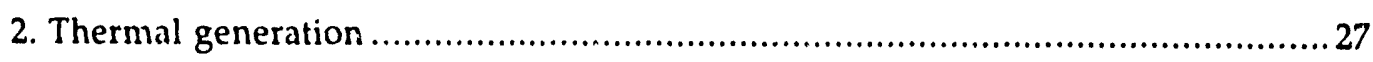

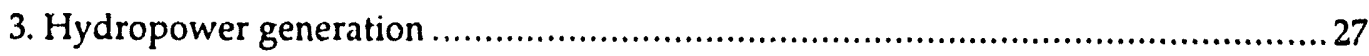

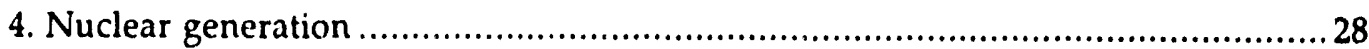

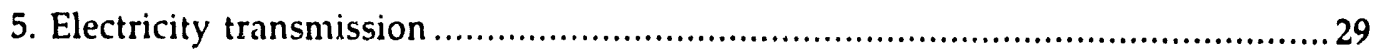

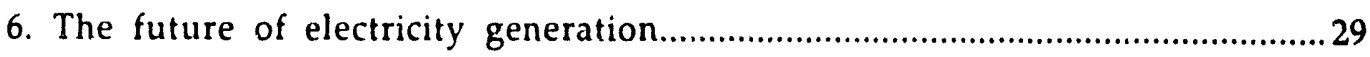

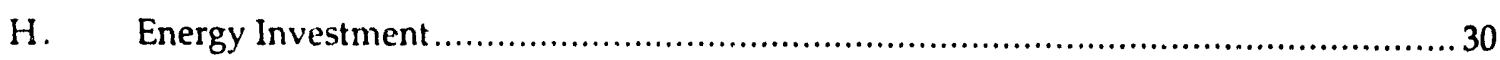

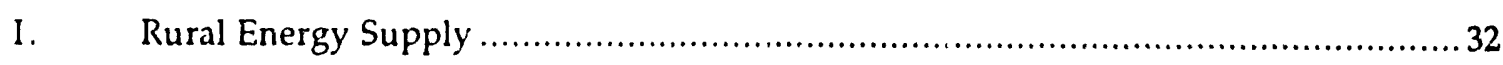

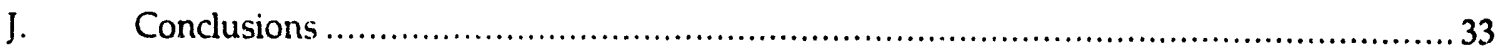

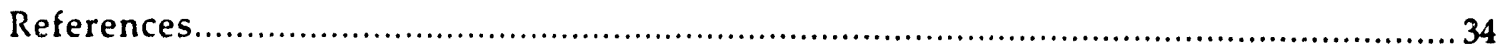

Part III: Energy Demand

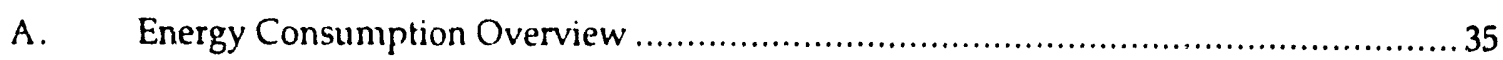

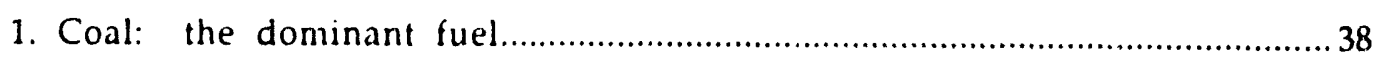




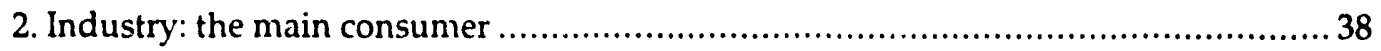

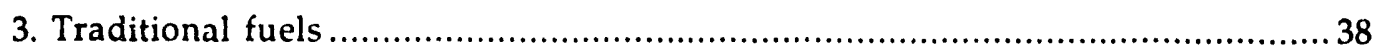

4. Opportunities for improved efficiency abound.................................................43

B. Macroeconomic Indicators \& Energy Intensity ............................................43

1. Measures of economic output ................................................................ 43

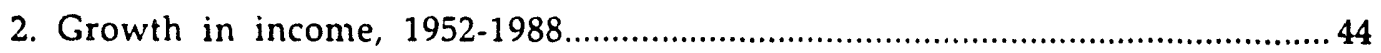

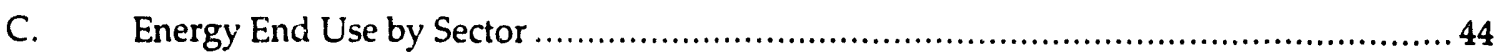

D. Industry and Its Subsectors

1. Economic substructure and energy end use ................................................... 49

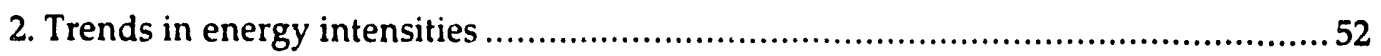

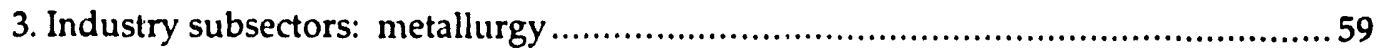

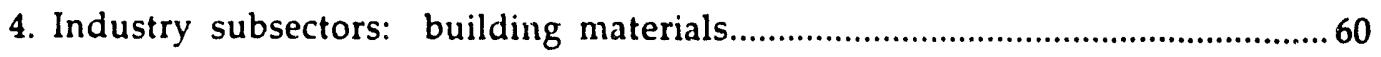

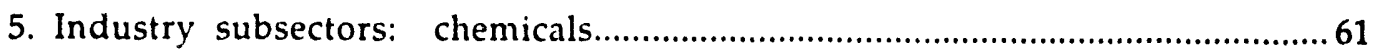

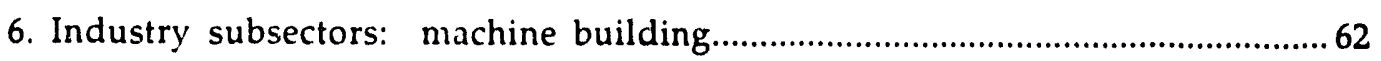

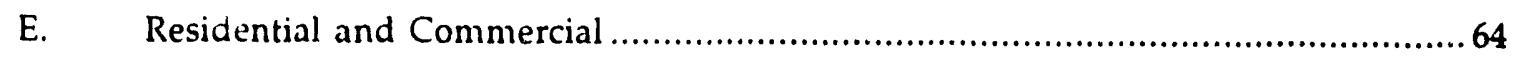

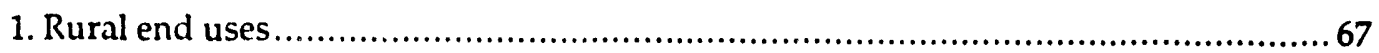

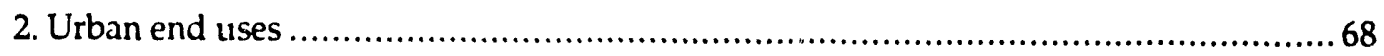

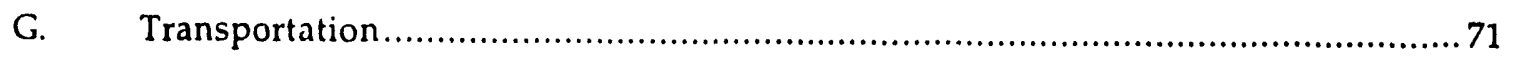

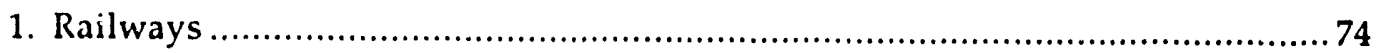

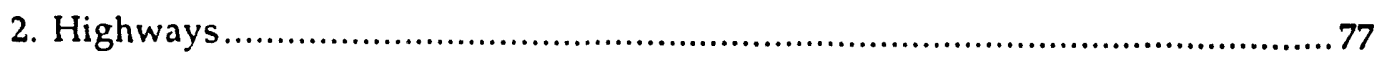

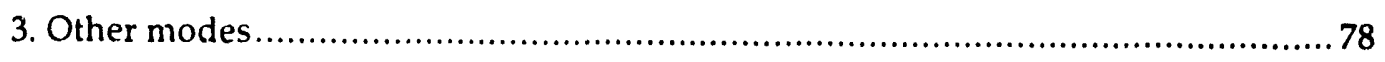

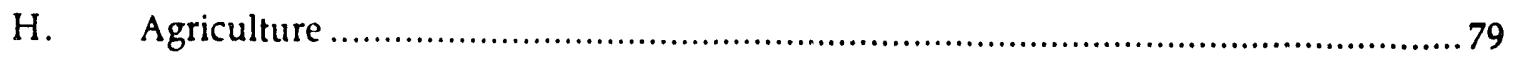

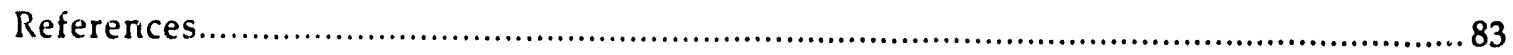

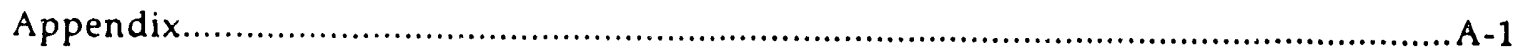




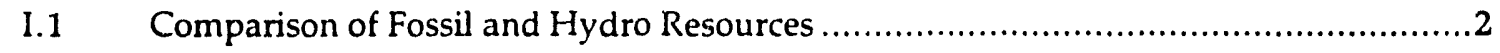

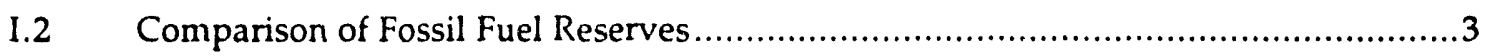

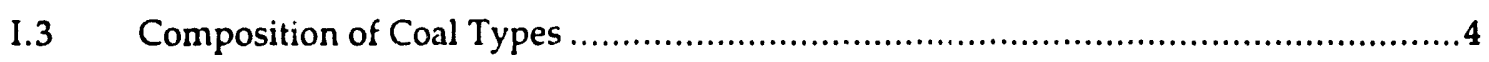

I.4 Composition of Representative Chinese Crudes................................................5

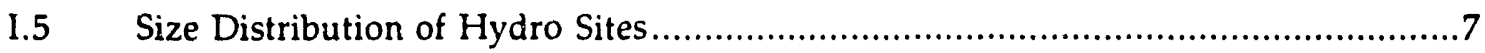

I.6 Forest Resources for Selected Countries..............................................................

II.1 Annual Growth Rates of Energy Production, 1977-87................................................ 13

II.2 Shares of Energy Production by Country and Source, 1988.......................................... 16

II.3 Fuel Efficiency of Domestically Manufactured Thermal Power Units....................... 28

II.4 Investment in Electrical Sector to Meet Demand Projections.........................................30

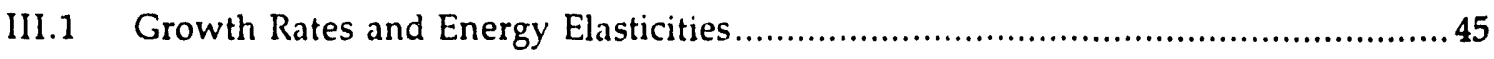

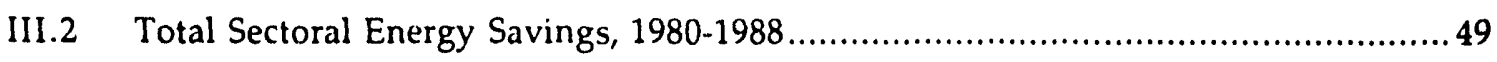

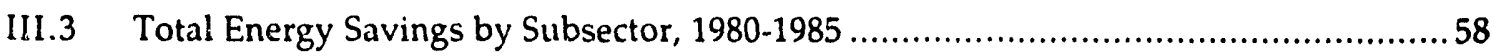

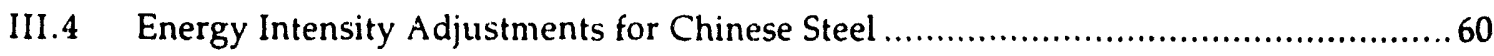

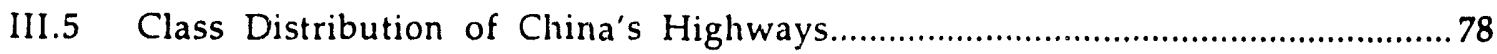




\section{FIGURES}

Page

II.1 Commercial Energy Production in China, 1950-1988 ........................................ 14

II.2 Energy Production Growth Rate, 1951-1988 ....................................................... 14

II.3 Energy Production by Fuel Source, 1950-1988 ................................................... 15

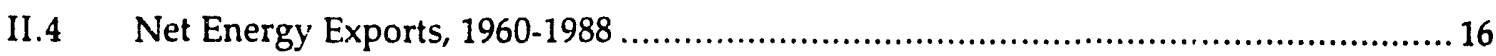

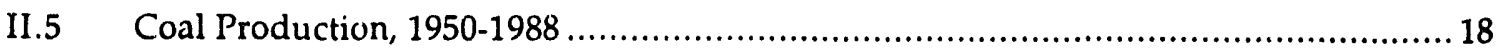

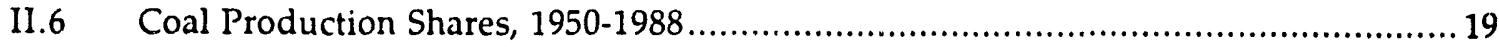

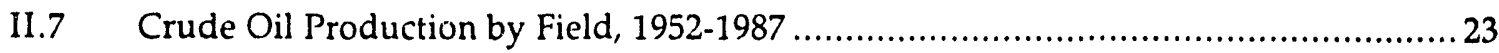

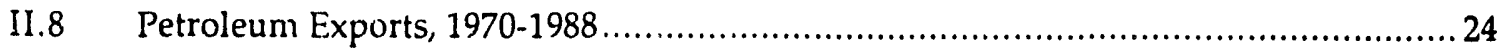

II.9 Crude Oil Production Growth Rate, Daqing Oilfield, 1961-1987............................25

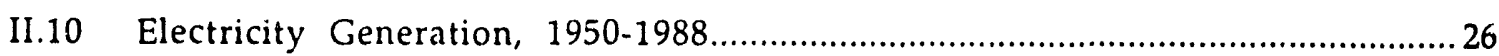

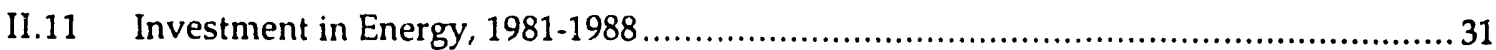

III.1 Primary Energy Consumption by Fuel, Selected Countries, 1988 ...............................36

III.2 Per Capita Primary Energy Consumption, Selected Countries, 1988.......................... 36

III.3 Total Primary Energy Consumption by Source, 1952-1988 ...................................... 37

III.4 Commercial Energy Consumption by Sector, 1980-1988............................................ 37

III.5 World Coal Consumption, Selected Countries, 1970 \& 1988..................................... 39

III.6 Fuel Shares of Energy End-Use, Selected Countries, 1988....................................... 40

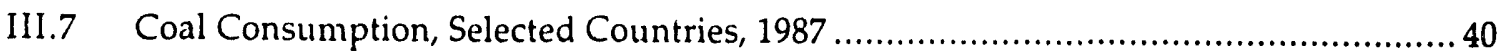

III.8 Sectoral Shares of Commercial Energy End-Use, Selected Countries, 1987................ 41

III.9 Biomass Consumption, Selected Countries, 1988 ..............................................41

III.10 Energy End-Use b y Fuel, Selected Countries, 1987 ................................................. 42

III.11 Real National Income by Sector, 1952-1989........................................................42

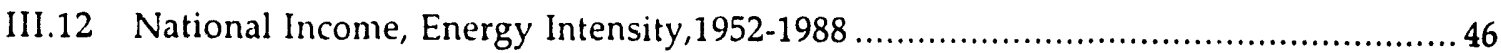

III.13 Commercial Energy Consumption: Actual Use vs. Predicted by NI............................ 46

III.14 Sectoral Disaggregation of the Chinese Economy...............................................47

III.15 Sectoral Shares of Gross Output Value, 1952-1988................................................ 48

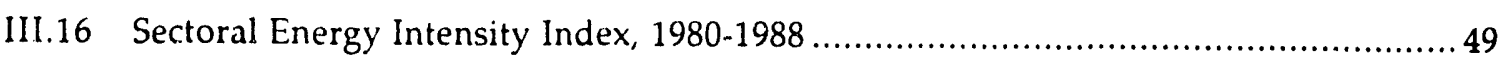

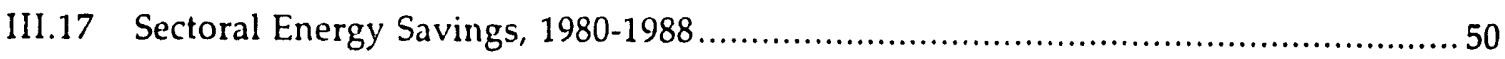

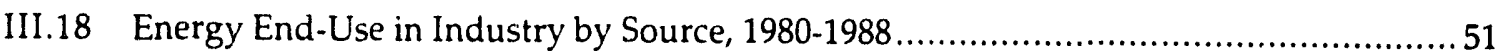

III.19 Energy End-Use in Industry by Subsector, 1980-198 …........................................ 51 


\section{FIGURES}

III.20 Subsectoral Shares of Industrial Gross Output Value, 1952-1988 ...........................52

III.21 Unadjusted Energy End-Use in Industry by Subsector, 1980-1985 ............................53

III.22 Unadjusted Subsectoral Shares of Industrial Gross Output Value, 1980-1985........... 54

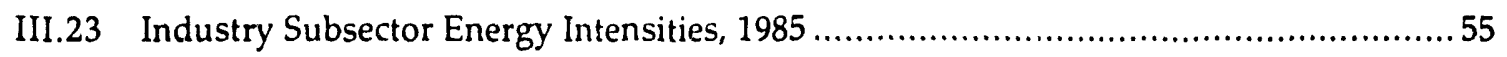

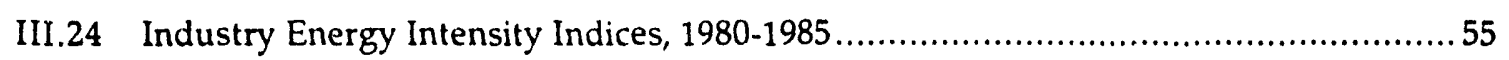

III.25 Energy Intensity Indices, Energy Non-Intensive Industries, 1980-1985 .................... 56

III.26 Energy Intensity Indices, Energy Intensive Industries, 1980-1985 ........................... 56

III.27 Energy Savings in Energy Intensive Industries, 1980-1985 .................................. 57

III.28 Energy Savings in Energy Non-Intensive Industries, 1980-1985................................58

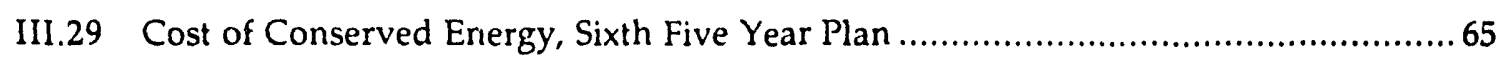

III.30 Energy Use in Commercial Buildings by Fuel, 1980-1988 ......................................65

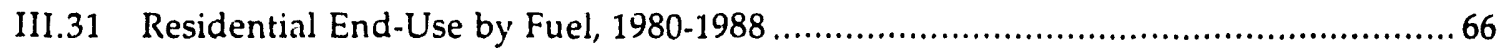

III.32 Per Capita Residential/Commercial End-Use 1987, Selected Countries....................66

III.33 Rural Energy Consumption by End-Use and Fuel, 1987 .....................................67

III.34 Possession of Appliances in Urban Households ................................................. 70

III.35 Per Capita Freight Traffic, Selected Countries, 1987 ........................................... 72

III.36 Per Capita Passenger Traffic, Selected Countries, 1987 ...................................... 73

III.37 Transport Energy Consumption by Fuel, 1980-1988 .......................................... 73

III.38 Fuel Use in Transportation, Selected Countries, 1987 ............................................ 75

III.39 Transportation Energy End-Use Shares by Mode, 1985_........................................... 75

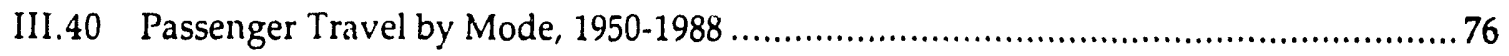

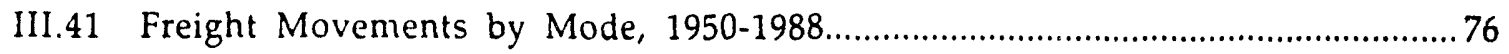

III.42 Energy End-Use in Agriculture by Fuel, Selected Countries, 1988.............................. 80

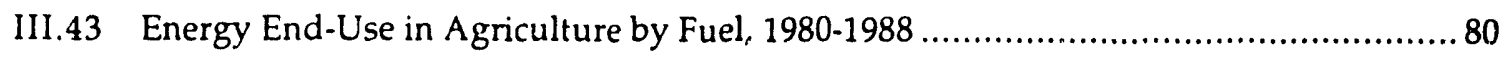

III.44 Power of Agricultural Machinery by Type, 1980-1988........................................... 81

III.45 Energy End-Use in Agriculture, Including Fertilizer, 1980-1988................................ 82 


\section{A. INTRODUCTION}

Although China is a poor country, with much of its population still farming for basic subsistence in rural villages, China is rich in energy resources. With the world's largest hydropower potential, and ranking third behind the US and USSR in coal reserves, China is in a better position than many other developing countries when planning for its future energy development and selfsufficiency.

China is now the third largest producer and consumer of commercial energy, but its huge populace dilutes this impressive aggregate performance into a per capita figure which is an order of magnitude below the rich industrialized nations. Despite this fact, it is still important to recognize that China's energy system is still one of the largest in the world. A system this size allows risk taking and can capture economies of scale.

The Chinese have maintained rapid growth in energy production for several decades. In order to continue and fully utilize its abundant resources however, China must successfully confront development challenges in many areas. For example, the geographic distribution of consumption centers poorly matches the distribution of resources, which makes transportation a vital but often weak link in the energy system. Another example capital-is scarce relative to labor, causing obsolete and inefficiently installed technology to be operated well beyond what would be considered its useful life in the West.

Major improvements in industrial processes, buildings, and other energy-using equipment and practices are necessary if China's energy efficiency is to continue to improve. Chinese energy planners have been reluctant to invest in environmental quality at the expense of more tangible production quotas. As a result, China's heavy reliance on coal, unscrubbed and usually unwashed, has caused severe local air pollution, regional acid rain, and large contributions to global atmospheric $\mathrm{CO}_{2}$ levels. China's institutional structure, with its emphasis on production quotas, is not wellsuited to contend with these issues. Recent progress along these lines, however, has been encouraging. Investment in energy conservation is playing a larger role in energy planning.

This report discusses these and other issues in the following pages. Part 1 surveys China's substantial resource endowments. Part 2 examines historical and present trends of energy production. Part 3 describes trends in end-use, and sectoral and subsectoral energy intensities. Together these chapters are intended to provide a statistical overview of China's energy situation with an international perspective.

\section{B. ENERGY ENDOWMENTS}

\section{Resources}

China is well endowed with energy resources. The latest government releases of China's estimated fossil fuel and hydropower resources are summarized in Table I.1.

These resource endowments place China third in the world after the USSR and the USA. However, while China's resources are abundant, they are shared among the people of the most populous country on earth. China's population is now over 1.1 billion, making China's per capita energy endowment much smaller than the US and the USSR, and smaller than that of many countries with only moderate absolute endowments. 
Table 1.1: Comparison of Fossil and Hydropower Resources.

\begin{tabular}{cccccc} 
& $\begin{array}{c}\text { Population } \\
\text { (million) }\end{array}$ & $\begin{array}{c}\text { Coal } \\
\text { (Btce) }\end{array}$ & $\begin{array}{c}\text { Crude Oil } \\
\text { (Btce) }\end{array}$ & $\begin{array}{c}\text { Natural Gas } \\
\text { (Btce) }\end{array}$ & $\begin{array}{c}\text { Hydropower } \\
\text { (GW) }\end{array}$ \\
\hline China & 1096 & 2270 & 111 & 44 & 379 \\
world share & $21.7 \%$ & $20.0 \%$ & $7.4 \%$ & $5.3 \%$ & $16.5 \%$ \\
per capita & & $2.1 \mathrm{ktce}$ & 100 tce & 40 tce & $350 \mathrm{~W}$ \\
\hline India & 813 & 115.4 & n.a. & n.a. & 42 \\
world share & $16.2 \%$ & $1.0 \%$ & & & $1.8 \%$ \\
per capita & & $140 \mathrm{tce}$ & & $50 \mathrm{~W}$ \\
\hline USA & 245 & 2570 & 116 & 204 & 200 \\
world share & $4.9 \%$ & $22.6 \%$ & $7.7 \%$ & $24.6 \%$ & $8.9 \%$ \\
per capita & & $10.5 \mathrm{ktce}$ & $500 \mathrm{tce}$ & $800 \mathrm{tce}$ & $830 \mathrm{~W}$ \\
\hline USSR & 283 & 4230 & 116 & 204 & 270 \\
world share & $5.6 \%$ & $37.2 \%$ & $7.7 \%$ & $24.6 \%$ & $11.7 \%$ \\
per capita & & $14.9 \mathrm{ktce}$ & $500 \mathrm{tce}$ & 800 tce & $950 \mathrm{~W}$ \\
\hline World & 5029 & 11360 & 1500 & 830 & 2300 \\
per capita & & $2.3 \mathrm{ktce}$ & $300 \mathrm{tce}$ & 200 tce & $450 \mathrm{~W}$
\end{tabular}

Notes: Because China's energy system is founded on coal, coal equivalent units (Btce, Mtce) will be used in this report to allow easy comparison of energy sources. See Appendix 1 for a complete explanation. Indian coal is assumed to have standard heat content $(29.3 \mathrm{MJ} / \mathrm{kg})$. This table excludes renewable resources other than hydropower, most significantly biomass. Population figures are from 1988. Resource figures are estimates based on general geological conditions of these countries. They do not necessarily indicate the significance of economically recoverable amount.

Sources: Coal / The World Bank, 1985. HydropowerMang, 1988. Others / Gardel, 1979. Chinese data from Ministry of Energy (MoE), 1989 and Indian data from the Asian Development Bank, 1989. World total adjusted accordingly.

\section{Reserves}

Chinese energy reserves show a similar pattern (see Table 1.2). Comparing reserve estimates from different nations is difficult because of the variety of techniques and conventions for compiling and analyzing statistical information and because of differing definitions of reserves. Differing reserve qualities complicate the comparison even further.

In the following pages, the characteristics of each fuel resource will be discussed in detail, including:

- resource and reserves estimates

- quality, including heat and effluent contents

- geographic distribution and proximity to demand centers and transportation lines

- ease of extraction

\section{COAL}

Coal is the cornerstone of China's energy system. China relies more heavily on coal as a proportion of end-use energy than any other nation, and coal will remain China's most important energy resource for decades to come.

\section{Coal resource and reserve estimates}

Coal-bearing sediments cover about 550,000 $\mathrm{km}^{2}$ (over $5 \%$ ) of Chinese territory [Ministry of Energy (MoE), 1989]. This suggests enormous total coal resources. China is always working to improve and update its coal resources estimates. A comprehensive survey undertaken in 1980 showed that China had 3200 billion tons of coal resources ( 2270 billion tonnes of coal equivalent [Btce]). By the end of 1989, the official coal resources figure was 4000 billion tons ( $2840 \mathrm{Btce}$ ). In this report we have chosen to use the survey data. Estimates of China's coal reserves vary widely, depending on the definition of 
Table 1.2: Comparison of Fossil Fuel Reserves.

\begin{tabular}{cccccc} 
& $\begin{array}{c}\text { Coal } \\
\text { (Btce) }\end{array}$ & $\begin{array}{c}\text { Crude Oil } \\
\text { (Btce) }\end{array}$ & $\begin{array}{c}\text { Natural Gas } \\
\text { (Btce) }\end{array}$ & $\begin{array}{c}\text { Total } \\
\text { (Btce) }\end{array}$ & $\begin{array}{c}\text { Per Capita } \\
\text { (tce) }\end{array}$ \\
\hline China & 121.4 & 3.4 & 1.2 & 126 & 116 \\
India & 10.1 & 0.9 & 0.7 & 12 & 15 \\
USA & 188.4 & 6.0 & 7.1 & 202 & 825 \\
USSR & 174.7 & 11.4 & 54.7 & 241 & 852 \\
World Total & 732.7 & 173.3 & 143.1 & 1049 & 209
\end{tabular}

Notes: Reserves here are defined as recoverable from known deposits under existing economic and operating conditions.

Source: BP Statistical Review of World Energy, 1988. BP's figures are assumed to be standardized, i.e., conversion factors in Appendix 1 are applied.

reserves applied. The latest (1989) official figure is 901.5 billion tons (643.7 Btce). According to the Ministry of Energy, about $30 \%$, or 270 billion tons (190 Btce) is the amount comparable to recoverable reserves figures for western countries. This adjusted official reserve figure is still significantly larger than British Petroleum's (BP) estimate of 170 billion tons recoverable reserves. To make international comparisons more consistent, we use BP data.

China's share of recoverable reserves is expected to increase in coming years because the resource base has been less thoroughly prospected than in other countries. From 1981 to 1987 China's share of the world's increase in proven coal reserves was $50 \%$, compared to $28 \%$ for the US [BP, 1988].

\section{Quality of coal deposits}

The quality of China's coal reserves is good overall. At least $35 \%$ of Chinese coal reserves are coking coals. Sixteen percent are anthracites, compared to $2 \%$ for the US (27 vs. 5 billion tons), $70 \%$ are bituminous and subbituminous, and only $14 \%$ are lignites (all percentages are based on the 643.7 Btce reserves figure) [MoE, 1990]. Heat values, ash, and sulfur content of these coals are summarized in Table I.3.

Ash content can be high in some of the Chinese coking coals, and sulfur content is generally low or medium. It is estimated that of present reserves (643.7 Btce), about $70 \%$ contains less than $1 \%$ sulfur, while only $15 \%$ contains more than $2 \%$ [Zhou, 1989]. In general, coal reserves in the southern provinces are of poorer quality, with lower heat values and higher ash and sulfur contents [Wang, 1988]. The most striking characteristics of Chinese coal reserves are the large quantities of high heat value, low sulfur anthracites, and the large share of coking coals.

\section{Ease of extraction from coal mines}

Chinese coal is generally easy aid inexpensive to mine. One of the main limiting factors is water scarcity in major mine areas.

Deep mining. Average extraction depth in the currently worked mines is about 300 meters, and the estimated mean depth of all the reserves is 500 meters. Forty-five percent of deep mines have high potential for methane accumulation and explosions, and half of the seams must be watched for the possibility of spontaneous combustion [Smil, p. 32, 1988].

Surface mining. Surface mining holds little promise in China. Only $7 \%$ of the coal reserves (refer to $643.7 \mathrm{Btce}$ ) are suitable for surface mining, compared to $35 \%$ in the US. Of these, $70 \%$ are lignites. Inner Mongolia holds about $60 \%$ of the surface mineable reserves and the rest are in Shanxi, Xinjiang, and Yunnan provinces [MoE, 1990]. 
Table 1.3: Composition of Coal Types.

\begin{tabular}{lcccc} 
Coal Type & $\begin{array}{c}\text { Share of } \\
\text { Reserves }\end{array}$ & $\begin{array}{c}\text { Content } \\
(\mathrm{MJ} / \mathrm{kg})\end{array}$ & $\begin{array}{c}\text { Ash } \\
\text { Content } \\
(\%)\end{array}$ & $\begin{array}{c}\text { Sulfur } \\
\text { Content } \\
(\%)\end{array}$ \\
\hline Anthracite & $16 \%$ & $35-36$ & $3-10$ & $0.2-1.9$ \\
Bituminous & $70 \%$ & $22-32$ & $5-40$ & $0.5-7$ \\
Lignite & $14 \%$ & $10-22$ & $5-25$ & $0.3-3$ \\
Weighted Average & $100 \%$ & $22-31$ & $5-33$ & $0.4-5.6$
\end{tabular}

Source: Chinese Ministry of Energy, "Energy in China, 1988;" V. Smil, Energy in China's Modernization, 1988.

\section{Geographic distribution}

Unfortunately, most coal deposits in China are located far from major consumption centers. China's coal deposits are mainly in the north and northwest regions of the country. Xinjiang province, which borders the Soviet Union, holds about $50 \%$ of the total coal resources. The province of Inner Mongolia holds the next most, followed by Shanxi [Wang, 1988]. Because of their remote location, the coal resources in Xinjiang have remained largely untapped. Mines in Inner Mongolia are only just being opened. Only Shanxi's coal resources, which are near central China, have been developed on a large scale.

Proved coal reserves (643.7 Btce) lie 59\% in northern China, $19 \%$ in the northwest, $10 \%$ in the southwest, $6 \%$ in the east, $4 \%$ in the northeast, and $2 \%$ in central and south China [Wang, 1988]. Coal reserves are geographically concentrated, which strains the transportation and distribution network, and increases the costs of development and utilization.

\section{CRUDE OIL}

\section{Resource and reserve estimates}

China has 246 onshore and offshore sedimentary basins, covering a total of 5.5 million $\mathrm{km}^{2}$ (4.2 onshore and 1.3 offshore) [MoE, 1990]. Estimated oil-bearing volume is about 5 million $\mathrm{km}^{3}$. Although this is a large number, there are reasons to expect that the oil in this volume will be less than the world average.

China's sedimentary basins are smaller than average. The two largest are Talimu, which lies in the far west of Xinjiang province and encompasses 0.56 million $\mathrm{km}^{2}$, and Songliao, in which the productive Daqing field is located, encompassing 0.26 million $\mathrm{km}^{2}$. These fields are small when compared w'ith the largest in the USSR at 3.5 million $\mathrm{km}^{2}$ and the largest in the US at 0.9 million $\mathrm{km}^{2}$ [Ma, 1988]. Small basins reduce the chances for discovering large oil fields.

Another factor that restrains optimism about China's future oil reserves is that the trap structures of China's oil-bearing layer are usually highly fractured and stratified, making them less able to store oil or gas and creating difficulties for exploration and development.

Even in the face of these adverse conditions, China still has two supergiant oil fields, Daqing and Shengli, that produce more than 50 and 30 Mtons of crude per year respectively. The potential for large oil fields in China does exist.

These factors underlie the uncertainty in estimates of crude oil resources in China. Except in the territory of presently producing fields, most of the sedimentary basins have only seen preliminary prospecting. Therefore recent estimates of ultimate resources again range widely, with China's official figures increasing from 30-60 billion tons (43.3-84.6 
Table 1.4: Composition of Representative Chinese Crudes.

\begin{tabular}{lcccc} 
& Daqing & Shengli & Huabei & Klamayi \\
\hline Gasoline & $8.0-8.7 \%$ & $6.1 \%$ & $1.5-11.3 \%$ & $9.1 \%$ \\
Light Diesel & $18.7-20.8 \%$ & $19.0 \%$ & $21.1-36.5 \%$ & $26.2 \%$ \\
Heavy Oil & $27.1-28.7 \%$ & $27.5 \%$ & $33.9-36.3 \%$ & $27.0 \%$ \\
Residues (\%) & $44.0 \%$ & $47.4 \%$ & $15.9-43.3 \%$ & $37.7 \%$ \\
Density & 0.86 & 0.9 & $0.83-0.89$ & 0.88 \\
Wax (\%) & $44.5 \%$ & $27.0 \%$ & $47-52 \%$ & $16.0 \%$ \\
Sulfur (\%) & $0.1 \%$ & $0.8 \%$ & $0.3 \%$ & $0.1 \%$ \\
Nitrogen (\%) & $0.1 \%$ & $1.4 \%$ & $0.4 \%$ & $0.2 \%$ \\
Vanadium (ppm) & $<.08$ & 1.0 & 0.7 & $<0.4$ \\
Nickel (ppm) & 2.3 & 26.0 & 15.0 & 13.8 \\
Sources: Wang Qingyi, Energy in China, 1988. & & & \\
\hline
\end{tabular}

Btce) in the early 1980s (Yearbook of Communist China, 1988], to 78.75 billion tons (onshore plus offshore), or about 111 Btce more recently [MoE, 1990].

Recent estimates of recoverable reserves vary less, from 3.2 billion tons (4.5 Btce) [DoE/EIA, 1987 and BP, 1988] to 3.4 billion tons, (4.8 Btce) as of 1988 [MoE, 1989]. This compares to US recoverable reserves of 4.2 billion tons $(5.9$ Btce), and USSR recoverable reserves of 8 billion tons, or 11.3 Etce. China's oil reserves account for only about $2 \%$ of world reserves, and this share is unlikely to increase significantly in the future [BP, 1988].

\section{Quality of crude oil deposits}

Chinese crudes are generally heavy and waxy. Table 1.4 summarizes the constituents of some of the more important and representative Chinese crudes.

Chinese crudes also generally have low gasoline and asphalt contents. This causes difficulties with the provision of liquid fuels and road surfaces for vehicles. On the positive side, the sulfur content of Chinese crudes is also low.

\section{Geographic distribution of crude oil deposits}

China's oil deposits follow to some extent the distribution of coal resources. Excepting offshore basins, all major potential oilbearing basins are in north and northwest
China. Fortunately, the bulk of proved oil reserves are close to demand centers, and there have been no problems with the transport of oil. Regional distribution of proved oil reserves are: north $14.4 \%$, northeast $48.3 \%$, east $18.2 \%$, northwest $14 \%$, and all other areas 5\% [MoE, 1990]. Judging by the concentration of present exploration efforts, new onshore discoveries will likely be in the northwest region, especially from Xinjiang.

\section{E. NATURAL GAS}

\section{Resource and reserve estimates}

China's natural gas resources have been even less accurately assessed than oil. Lack of both technical expertise as well as capital have hindered exploration. Presently only $2.6 \%$ of estimated natural gas resources has been proven, which reflects this lack of prospecting.

Even in the face of such uncertainty, future natural gas reserves are not expected to acco:unt for nearly as large a share of energy supply as they do in the US or the USSR. Natural gas resources in China are estimated to be 33.3 trillion cubic meters $(\mathrm{tcm})$, or 44 Btce, compared to about $150 \mathrm{tcm}$ or about 200 Btce for the US and USSR [Table 1.1]. China's holdings are $5 \%$ of total world resources. 
Because of the paucity of exploration until recently, proved reserves show an even larger disparity. As of 1988 there were $866 \mathrm{bcm}(1.2$ Btce) of proved natural gas reserves in China, compared to $5,300 \mathrm{bcm}$ (7.1 Btce) in the US and $41,1.00 \mathrm{bcm}(54.7 \mathrm{Btce})$ in the USSR. China's natural gas reserves are only $0.8 \%$ of the world total [BP, 1988].

The Chinese have some reasons for optimism about the results of future exploration. Natural gas deposits are often associated with coal reserves, which are abundant in China. Present meager reserves reflect primarily the lack of exploration, rather than an ab;olute lack of natural gas re:ources. The Chinese are increasing their exploration efforts. In 1986, the Ministry of the Petroleum Industry announced that it planned to separate gas and oil prospecting and establish research institutes specifically for natural gas. Presently, the majority of prospecting effort is being undertaken in the Sichuan basin, Bolizi Bay, and north and northwest China.

There is one kind of unconventional natural gas in China ready to be tapped-coalbed methane. The Chinese government has shown increasing interest in methane recovery as means to protect the environment and increase energy options. It is estimated that China has about $289 \mathrm{bcm}$ (384 Btce) of coalbed methane reserves $[Q$ in and $X$ in, 1989]. This is a significant addition to present proven natural gas reserves.

\section{Geographic distribution}

Proven natural gas reserves are concentrated in the Sichuan basin, where about $40 \%$ of total natural gas output is produced. Sichuan natural gas is not associated with oil. Oil associated gas mainly comes from northeast region where China's top oil fields are located. Oil-associated gas comprised about $57 \%$ of total natural gas output in 1988. Most new gas reserves may come from the northwest where exploration has uncovered several promising new fields.

\section{F. HYDROPOWER}

\section{Hydropower resource estimates}

China holds the largest hydropower resource in the world. China's territory is predominantly mountainous. In the west stands the world's highest plateau, surrounded and traversed by great mountain chains, and providing abundant water sources. The southwestern mountains are also extensive and receive plenty of rainfall.

Runoff volume of Chinese rivers is about 2640 billion cubic meters per annum, which ranks fifth in the world. However, steep gradients more than make up for lower runoffs. Total hydropower resources are $660 \mathrm{GW}$, and exploitable capacity is $379 \mathrm{GW}$, with a generating ability of about 1,950 TWh electricity per year. This exploitable capacity is $16 \%$ of the world total, and is well ahead of the USSR with 269 GW, Brazil with $209 \mathrm{GW}$, and the USA with 205 GW [Wang, 1988].

China's hydropower resources figure is the result of an exhaustive survey made between 1977 and 1980 and is considered very reliable. This survey identifies 3019 rivers with more than $10 \mathrm{MW}$ hydropower resources [Wang, 1988].

Despite China's abundant hydropower potential, remote, mountainous sites are often unfavorable for construction, and require long transmission lines. For example, Tibet holds $17 \%$ of the nation's hydro resources, but the above conditions make it likely that they will remain untapped for a long time.

\section{Size distribution of hydropower sites}

Table 1.5 summarizes the contribution of different size hydropower sites to the total resource estimate.

As can be seen from Table 1.5, medium and large sites dominate the exploitable capacity. The largest 33 sites (each with more than 2 GW capacity) account for about $50 \%$ of the total. The next 170 sites (with capacities ranging from $250-2000 \mathrm{MW}$ ) account for about $30 \%$ of the remaining capacity. Small sites are numerous, and 
Table 1.5: Size Distribution of Hydro Sites.

\begin{tabular}{lcccc}
\multicolumn{1}{c}{ Site Capacity } & $\begin{array}{c}\text { Number of } \\
\text { Sites }\end{array}$ & $\begin{array}{c}\text { Capazity } \\
(\mathrm{GW})\end{array}$ & $\begin{array}{c}\text { Generation } \\
(\mathrm{GWh})\end{array}$ & $\begin{array}{c}\text { Share of } \\
\text { Potential }\end{array}$ \\
\hline 1.250 MW & 1743 & 75.32 & 365.23 & $20.1 \%$ \\
$250-750$ MW & 115 & 46.67 & 223.54 & $12.3 \%$ \\
$750-2000$ MW & 55 & 65.27 & 317.24 & $17.4 \%$ \\
$>2000$ MW & 33 & 169.82 & 912.39 & $50.2 \%$ \\
Total & 1946 & 357.08 & 1818.40 & $(100.0 \%)$
\end{tabular}

Source: Wang, 1988.

Note: the remaining $22 \mathrm{GW}$ capacity consists of numerous small sites with capacities of $<1 \mathrm{MW}$.

although they only account for about one fifth of the total, they can provide electricity to remote areas without extending the transmission grid.

\section{Geographic distribution}

The distribution of hydropower resources complements the distribution of fossil fuels. Southwestern areas dominate the total with $68 \%$, followed by central and south regions with $16 \%$. The Northwest area, which holds the upper reaches of the Yellow river, China's second largest, holds $10 \%$. The east and northeast regions, which comprise China's electricity load center, hold only a $6 \%$ share of total hydro resources. Sichuan province (which also has the nation's largest natural gas resources) is the richest in hydropower with $27 \%$ of total [MoE, 1990].

\section{G. BIOMASS}

The use of biomass for energy is of central importance in rural China. The approximately $70 \%$ (there is no reliable estimate so far) of China's populace that lives in rural areas depends on biomass as their primary source of energy.

V. Smil has provided one estimate for China's biomass resources. According to Smil, in the early eighties, China's standing phytomass (all above- and underground parts of trees, shrubs, grasses, crops, and aquatic plants) totaled about 30 billion dry tons, with its net primary productivity no more than 4.3 billion dry tons per year. This number does not indicate much potential for energy development. Only about half of the net productivity is from conventional hic 1 zass energy sources like forests and cr.pps. Furthermore, as Smil points out, crop residues, although heavily used as fuels at present, should not be counted as a sustainable energy source. In order to maintain soil fertility, crop residues should, for the most part, be composted, with the remainder reserved for animal feed or other miscellaneous uses. In this regard, forests are the most important source of a long-term and sustainable biomass energy supply.

Unfortunately, China's forests are among the world's poorest. According to the most recent data, forest and woodland area cover 115.25 million hectares, or about $12 \%$ of the land area of China [SSB, 1988]. How this compares with other countries is presented in Table 1.6.

115.25 million hectares is about $3 \%$ of the world's forest and woodland area [World Resources 1990-91], whereas China has 6.5\% of the world's dryland area - China's rate of forest cover is half the world average. Per capita forest and woodland area in China is 0.11 ha which is less than $14 \%$ of the world's average.

According to a survey in the Fifth Five-Year plan period (1976-1980), China's forests are divided into six caiegories: commercial forests (producing roundwood), shelter forests (preventing desertification), economic forests 
Table 1.6 Forest Resources for Selected Countries.

\begin{tabular}{|c|c|c|c|c|c|}
\hline & $\begin{array}{c}\text { Forest Area } \\
\text { (million ha) }\end{array}$ & $\begin{array}{c}\text { Growing Stock } \\
\left(\text { billion } \mathrm{m}^{3} \text { ) }\right.\end{array}$ & Cover Rate & $\begin{array}{l}\text { Per Capita } \\
\text { Forest Area } \\
\text { (ha/person) }\end{array}$ & $\begin{array}{c}\text { Per Capita } \\
\text { Stock } \\
\text { (m3/person) }\end{array}$ \\
\hline World & 4081.54 & 310 & $31 \%$ & 0.8 & 62 \\
\hline USSR & 928.6 & 73.25 & $42 \%$ & 3.2 & 254 \\
\hline Canada & 436.4 & 17.81 & $47 \%$ & 16.5 & 672 \\
\hline USA & 295.99 & 18.26 & $32 \%$ & 1.2 & 73 \\
\hline China & 115.25 & 9.02 & $12 \%$ & 0.1 & 8 \\
\hline
\end{tabular}

Notes: Forest Area includes forest and woodlands. Growing Stock is for closed forests with $30 \%$ or more canopy enclosure.

Source: World Resources, 1990-1991, and Handbook of Chinese Geography, 1988.

(producing fruits and oils etc.), fuelwood forests, specialty forests (not classified), and bamboo groves. The share of the total forested area for each category was $80.0 \%$, $6.4 \%, 7.1 \%, 3.4 \%, 0.5 \%$, and $2.6 \%$ respectively in the late 1970 s [Chao, 1988]. By the late 1970s, 3.69 million hectares were dedicated to providing fuelwood. The growing stock was then 69.6 million cubic meters. The fuelwood forest area had increased to 5.73 million hectares by the mid 1980s [Zhong, 1988]. Productivity of Chinese fuelwood forests is low, with a national average of about 7 ton/ha-year [State Planning Commission, 1990]. Productivity in southern provinces can reach 12 tons/ha-year [Zhong, 1988]. Current sustainable yield of fuelwood is about 40 million tons or $23 \mathrm{Mtce}$ $(0.57$ tce/ton) per year, based on the 7 ton $/$ hayear yield rate.

Woody matter collected from non-fuelwood forests is another important source of firewood. According to the estimate of the State Planning Commission (average firewood yield at 0.8 ton/ha-yr), the total sustainable harvest of firewood from nonfuelwood forests (about 110 million ha) would be 88 million tons per year, or $50 \mathrm{Mtce} /$ year. Including fuelwood production, the total amount of sustainable firewood in China would be 128 million tons per year at the present level of forestation, compared with present firewood consumption of 232 million tons per year [State Planning Conmission, 1990].

There are about 153 million hectares of land suitable for afforestation, which would result in a forest area of 268 million hectares and a cover rate of $28 \%$. If all these additional areas were dedicated to fuelwood trees, at a moderate yield rate of 7 ton/ha-year, fuelwood production could reach 1 billion tons--more than enough to meet the present level of biomass consumption in China. In practice, however, obstacles impede the realization of this goal. First, unlike fossil fuels, firewood is usually consumed locally. Transporting firewood over long distances is economically infeasible. The distribution of these potential forest areas is an important factor for the future firewood supply. Second, it is necessary to consider competing uses of limited land area. The 1.1 billion and growing population already places intense demands on arable land. It is likely that using most of this land for agriculture will take precedence.

Biogas from animal and human wastes is another important source of biomass energy. The amount of harnessable energy should be large for so populous a country as China. Biogas is fermented by anaerobic bacteria from either carbon-rich materials (crop residues, grasses, aquatic plants) or nitrogenrich materials (animal and human wastes), and not only provides a clean fuel but also an excellent organic fertilizer. Biogas production makes good sense, since China, with its large agricultural sector generating both a huge amount of crop products and livestock, seems well positioned to benefit from this energy source.

Unlike planting trees for firewood supply, harnessing biogas is more technology- 
dependent, and its success is also subject to temperature constraints. The southern provinces, where temperatures are high enough for fermentation most of the year, are the most promising for biogas production. These provinces also produce more livestock, and thus more biogas feedstock. Nationwide, the temperature is warm enough for biogas digesters to function an average of about seven months per year [Smil, 1988].

In Sichuan province, with a mild winter typical of southern provinces, a properly managed family digester (with an average capacity of about 8 cubic meters) can produce 230 cubic meters of biogas per year [He, 1988]. If every rural household could acquire one digester, at an estimated nationwide yield rate of 200 cubic meters per year ${ }^{1}, 31 \mathrm{bcm}$ of biogas could be produced per year (19 Mtce). Considering the higher end-use efficiency (60\% versus $20 \%$ ), this anount could replace about 100 million tons ( 57 Mtce) of wood fuels, eliminating the current firewood deficit, while producing almost no pollution. This result may be conservative (as an estinate of technical potential) because the bestoperated family digesters can produce as much as 420 cubic meters of biogas per year [Liang, 1988].

\section{H. OTHER ENERGY RESOURCES}

\section{Oil shale}

China had about 31 billion tons of oil shale reserves as of 1980 [Wang, 1988], which could provide about 1.9 billion tons of shale oil, or 3.3 Btce. Deposits are found in the southern Guangdong and northeastern Liaoning provinces. Present production of shale oil is 327,000 tons per annum, which is negligible conpared to crude oil production.

1 Southern provinces have about eight months where temperatures are good for fermentation (northern provinces have about four months). Because the national weighted average is seven months, national average biogas output is estimated as $7 / 8^{*}(230)=200$ cubic meters per year. We assumed a 1988 rural population of $70 \%$ of 1096 million, and five people per household. one cubic meter biogas is $0.61 \mathrm{kgce}$.

\section{Peat}

China holds about $10 \%$ of the world's reserves of peat, some 270 billion tons [Wang, 1988]. With heat values of 7.5-10.5 MJ/kg, this converts to about 70-100 Btce. These deposits are located mainly in the northeast and northwest, primarily in Heilongjiang province. At present, precise peat usage is uncertain, but it could become a regionally important rural energy source.

\section{Solar}

The north and northwest regions of China have good annual average insolation. The national average annual insolation is 5.9 $\mathrm{G} / \mathrm{m}^{2}$. Distribution of annual sunshine is: 2800-3300 hrs in the northwest and part of the southwest region, $2600-2800$ hrs in the north China plain, and over $2000 \mathrm{hrs}$ in the southeast region. Xinjiang, Gansu, Qinghai, and most of Tibet are richest in solar resources with a mean value of annual insolation greater than $6.3 \mathrm{GJ} / \mathrm{m}^{2}$ [Wang, 1988].

\section{Wind}

According to the China National Bureau of Meteorology, exploitable wind energy is about $160 \mathrm{GW}$ [Wang, 1988]. Favorable areas include the northwest, northeast, and Pacific coast.

\section{Tide}

Exploitable tide energy totals $18 \mathrm{GW}$. Presently, there exist eight experimental stations, with an installed capacity totaling 5.9 MW [Chen, 1992].

\section{Geothermal}

China is also beginning to utilize geothermal energy. No survey data of potential geothermal resources is available. Tibet is known to be rich in geothermal energy, with a $13 \mathrm{MW}$ station installed near Lhasa [Wang, 1988].

\section{Uranium}

Little information is available about China's uranium resources. Present reserves are enuugh to sustain pressurized light water reactors for $450 \mathrm{GW}$-years, which would 
replace about 1.8 Btce [Wang, 1988]. ${ }^{2}$ The 1989 Survey of Energy Resources of the World Energy Conference estimated China's uranium resources at 1000-2000 thousand tons $U$, compared with the US figure of 2037 thousand tons $U$ and the USSR figure of 20005000 thousand tons $U$.

\section{OBSTACLES TO FUTURE ENERGY DEVELOPMENT}

China is absolutely rich in coal and hydro resources and not without oil and gas resources. With this basic energy endowment, China is better positioned than most other developing countries when planning for future growth.

However, several factors hinder the continued development and utilization of the energy resources so far discussed. Most significant are the uneven geographic distribution of resources and the environmental impacts associated with energy production and consumption. Capital shortages may also limit the growth of China's energy infrastructure.

The rapid increase in coal production has already placed severe strain on the transportation system. Since future coal production will be concentrated in the northern region (especially the provinces of Shanxi and Inner Mongolia), transportation will continue to be a limiting factor on coal utilization if infrastructure is not developed in parallel. The hydropower resources located in the southwest will require longdistance power transmission, and the sites are difficult for construction. Oil and gas production increases will be increasingly remote, both inland and offshore.

2 Assuming equal capacity factors and a $27 \%$ conversion efficiency for the coal-fired electric plant.
The environmental impacts of energy use must also be addressed. Coal burning causes acid precipitation and smog precursors, and contributes to global warming. Coal mining produces mine spoils which can contaminate groundwater and aquatic ecosystems. Dams can flood farmland, displace population, and have downriver effects on agriculture, which is commonly located in river basins. Periodic flooding can be necessary for soil maintenance, without which loss of siltation and soil fertility can occur.

The lack of capital has effects other than directly liniting the investment in supplyside (and to a lesser extent demand-side) energy projects. A scarcity of capital, especially relative to labor in China, causes machinery to remain in place decades longer than similar equipment in the West. China's energy efficiency is very low as a result.

These complications need to be addressed if China is to maintain steady growth in its energy sector, which in turn fuels the growth and development of the entire economy. 
Part 1 - 11 


\section{References}

Asian Development Bank, Energy Indicators of Developing Member Countries of the ADB, (ADB: Manila, 1989).

The British Petroleum Company, $B P$ Statistical Review of World Energy, (London, 1988).

Chao Yurong, Handbook of China's Ceography, (in Chinese, Beijing: Forestry Press, 1988).

Chen Yingrong, "Renewables in China," Energy Policy, Vol.19, No.9 (Nov., 1991).

Department of Energy / Energy Information Agency, Annual Review of Energy, 1988.

He Liang, "A Critical View on the Development of Rural Household Biogas Digesters," Energy Journnl, No.4 (in Chinese, Beijing, 1988).

Gardel, Andre, Energy, (Pergamon Press, 1979).

Ma Xuechang, "On Exploration and Exploitation of China's Energy Resources," Proceedings: Energy Future and Conservation Technology (in Chinese, Beijing: 1988).

Ministry of Energy, Energy in China, (Beijing, 1989 and 1990).

Publishing House of Journal of Chinese Communist Studies, Yearbook of Communist China (in Chinese, Taiwan, 1988).

Smil, Vaclav, Energy in China's Modernization, (New York: M. E. Sharpe, Inc., 1988).

Statistical Bureau of China, Statistical Yearbook of China, (Beijing: 1988,1989).

Wang Qingyi, Energy in China (in Chinese, Beijing: Metallurgical Industry Publishing House, 1988).

The World Bank, China: The Energy Sector, 1985.

Zhong Maogong, On Developing China's Forest Energy, Proceedings of the Third National Conference on Rural Energy (in
Chinese, Beijing: Academic Journal Press, 1988).

Zhou Fengqi et al, Sectoral Energy Demand in China, (in Chinese, Beijing: Energy Press, 1989).

State Planning Commission (in Chinese, Beijing: Standards Press, 1990)

Qin Shiping and Xin Dingguo, Analysis of Technical Renovation Projects of Energy Conservation lnvestment (in Chinese, Beijing: Energy Press, 1989). 


\section{ENERGY SUPPLY}

\section{A. OVERVIEW}

In the last twenty years, the growth of China's energy production has been the fastest and most sustained of the major economies of the world (see Table II.1). Due to this rapid growth, China has maintained energy self-sufficiency, and has even been able to export crude oil and coal.

This rapid development has not been without its problems. Serious shortages arose in the 1980s. The electricity shortage has been the most severe, but petroleum products are also in excess demand, particularly liquid fuels for transportation. China also suffers severe urban air pollution because of burning coal with little processing or emissions controls. The rural energy shortage is more fundamental. Basic needs (e.g., cooking fuel) are not met; deforestation, loss of soil fertility, and declines in agricultural productivity have resulted.

Between 1949 and 1950, primary commercial energy production grew at an average rate of $9.7 \%$ per annum, from 23 to 1041 Mtce [State Statistical Bureau (SSF), 1991; Ministry of Energy (MoE), 1990]. Energy production during these periods is shown in Figure II.1.
The first period ended with "The Great Leap Forward," (1958-59), a year that showed remarkable gains in production in all sectors. The failure of the development policies of "The Great Leap Forward" is illustrated by the absolute decline and stagnation that followed in 1960-68. Production growth resumed in 1969, and, except for two years at the beginning of the "Economic Reform" period, has continued unabated since then. Figure II.2 shows these growth rates more exactly. Between 1950 and 1959, China experienced rapid growth in energy production, averaging $26.9 \%$ per annum, due to a small base figure and intense coal mining at the end of the period. During 1960-69, absolute production actually fell, but resumed growth in 1968 and continued until 1978. The average growth rate was $12.8 \%$ per annum during this period, with energy production increasing from 187.14 to 626.44 Mtce. Much of this growth was due to the discovery and development of large oil fields.

The present "Economic Reform" movement began in 1979. After a shaky start, energy production growth has been steady until the present. Average growth from 1979 to 1990 was $4.4 \%$ per annum, and production reached 1041 Mtce in 1988.

Table Il.1. Average Annual Growth Rates of Energy Production, 1965-1988.

\begin{tabular}{llll}
\hline & China & USA & USSR \\
Coal & $6.5 \%$ & $2.0 \%$ & $0.2 \%$ \\
Oit & $11.5 \%$ & $0.2 \%$ & $4.7 \%$ \\
Natural Gas & $11.7 \%$ & $0.4 \%$ & $7.7 \%$ \\
Hydropower & $9.9 \%$ & $0.5 \%$ & $5.0 \%$ \\
Nuclear & none & $24.0 \%$ & $27.0 \%$ \\
Total & $7.3 \%$ & $1.3 \%$ & $3.7 \%$ \\
\hline
\end{tabular}


Figure II.1: Commercial Energy Production In China, 1948-1990.

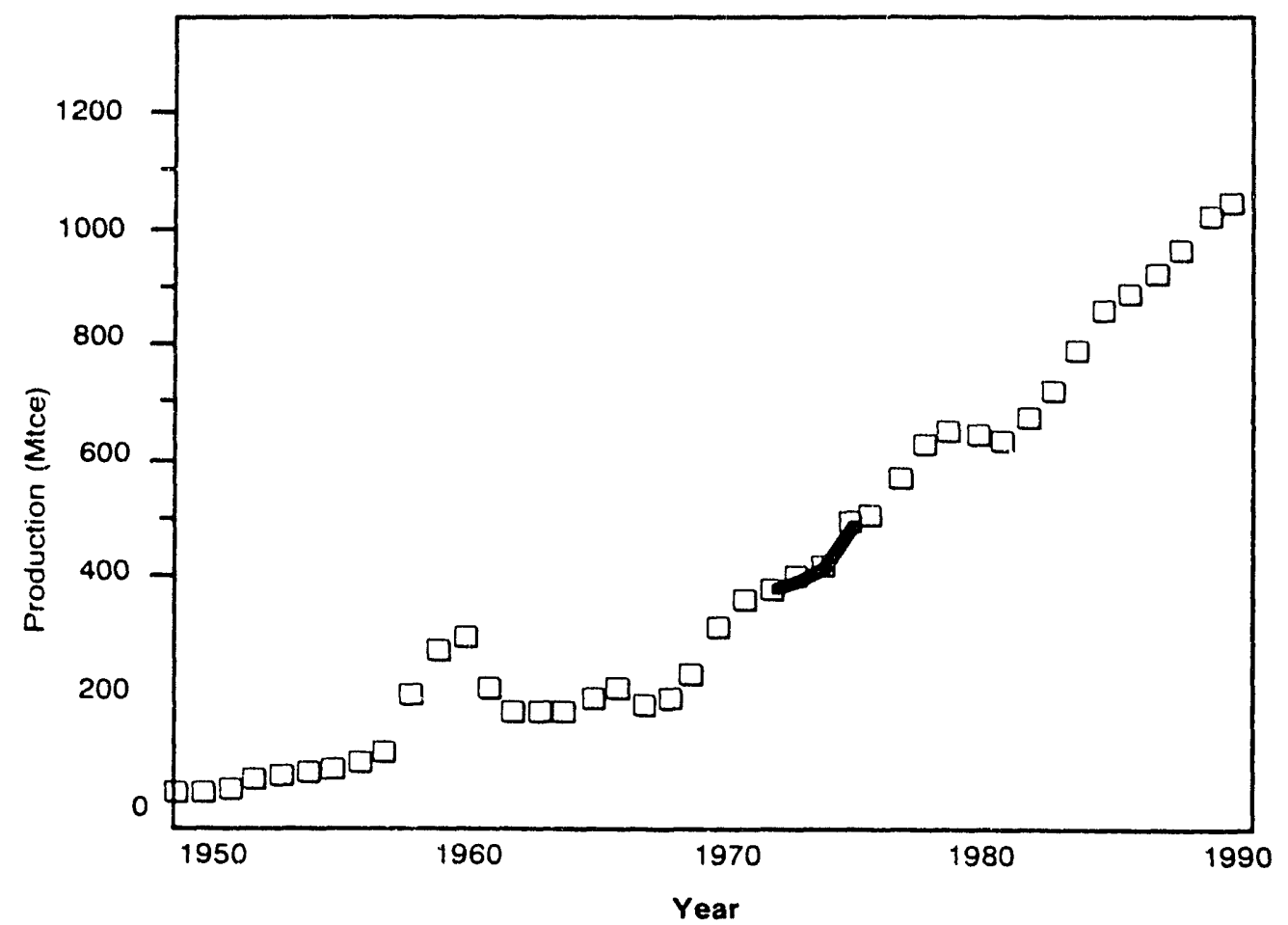

Source: Statistical Yearbook of China, 1991; Energy in China, 1990.

Figure 11.2: Energy Production Growth Rate, 1951-1988.

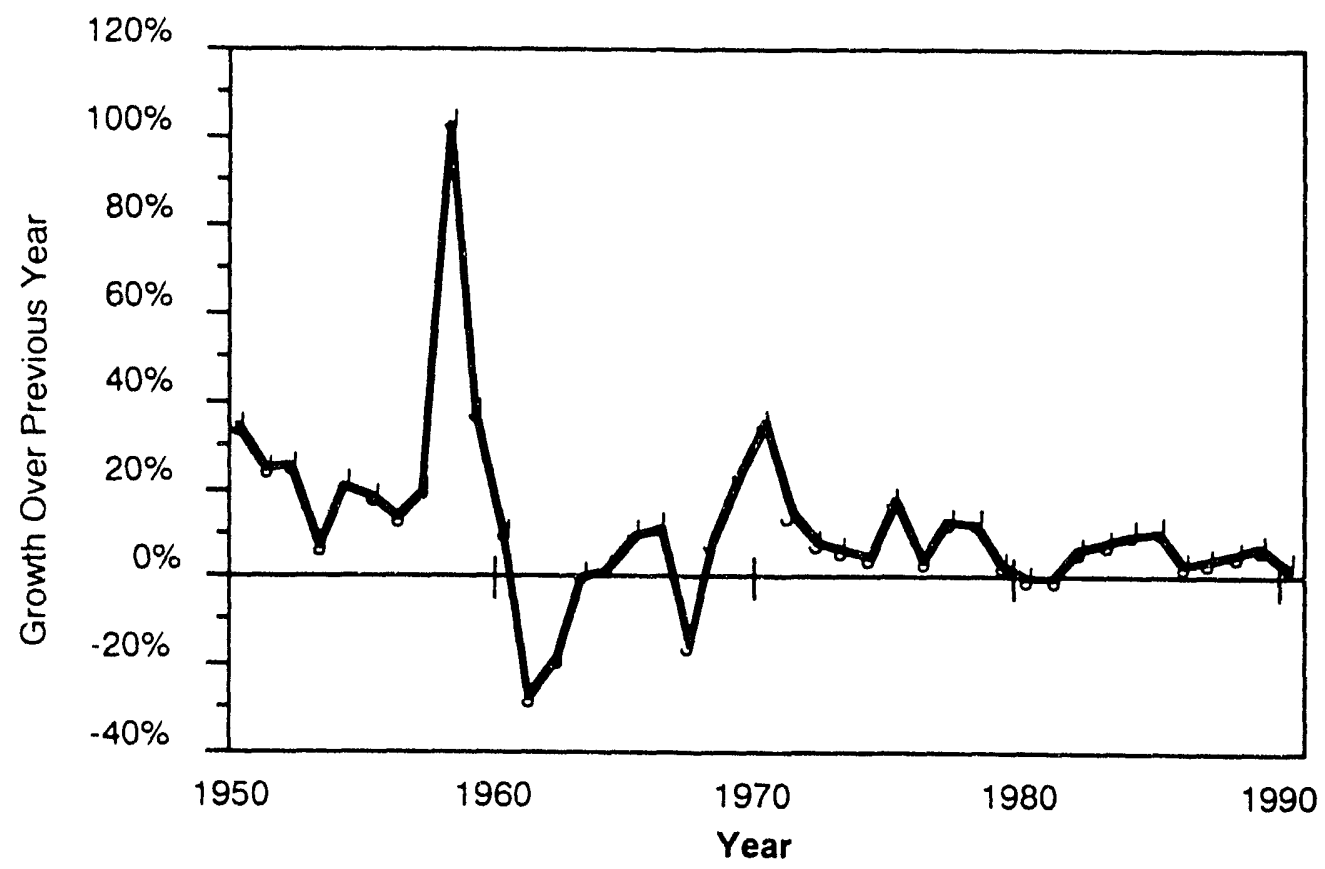

Source: Derived from Statistical Yearbook of China, 1991; Energy in China, 1990. 


\section{B. STRUCTURE OF ENERGY PRODUCTION}

As Figure II.3 shows, primary commercial energy production in China has, not surprisingly, been dominated by coal.

Coal production remained at more than $90 \%$ of total primary energy production until the mid1960s, at which point it began to decline with the development of China's major oil fields to about $70 \%$ by the mid-1970s. Table II.2 shows how these shares compare with the US and USSR. As the source comparison shows, Chinese energy production heavily favors coal, is moderate in oil and hydropower, very low for natural gas, with no nuclear at all. The gas and hydropower shares could increase in the longer run.

These figures include only commercial energy production. The utilization of biomass for energy in rural areas is the most notable exclusion. Reliable information on biomass utilization is not readily available, but its use is on the order of 270 Mtce/year [National Rural Energy Planning, 1990].

\section{ENERGY IMPORTS AND EXPORTS}

Self-sufficiency is a primary goal of China's energy policy. Energy imports ceased in the 1960 s and exports from China have been relatively small. Oil exports peaked in 1985 . Because of a shortage of liquid fuel in China, they will likely continue to decrease. More recently, coal exports have increased rapidly, and will likely continue to do so. Figure II.4 depicts these trends.

The foreign-exchange earnings of energy exports has also become less important in recent years. In the early 1980s, gross earnings of energy exports had climbed to about $25 \%$ of total gross earnings of the country. This export rate declined to about $10 \%$ by 1989 . Declining oil prices have been an important factor in this trend.

Figure 11.3: Primary Energy Production by Source, 1949-1990.

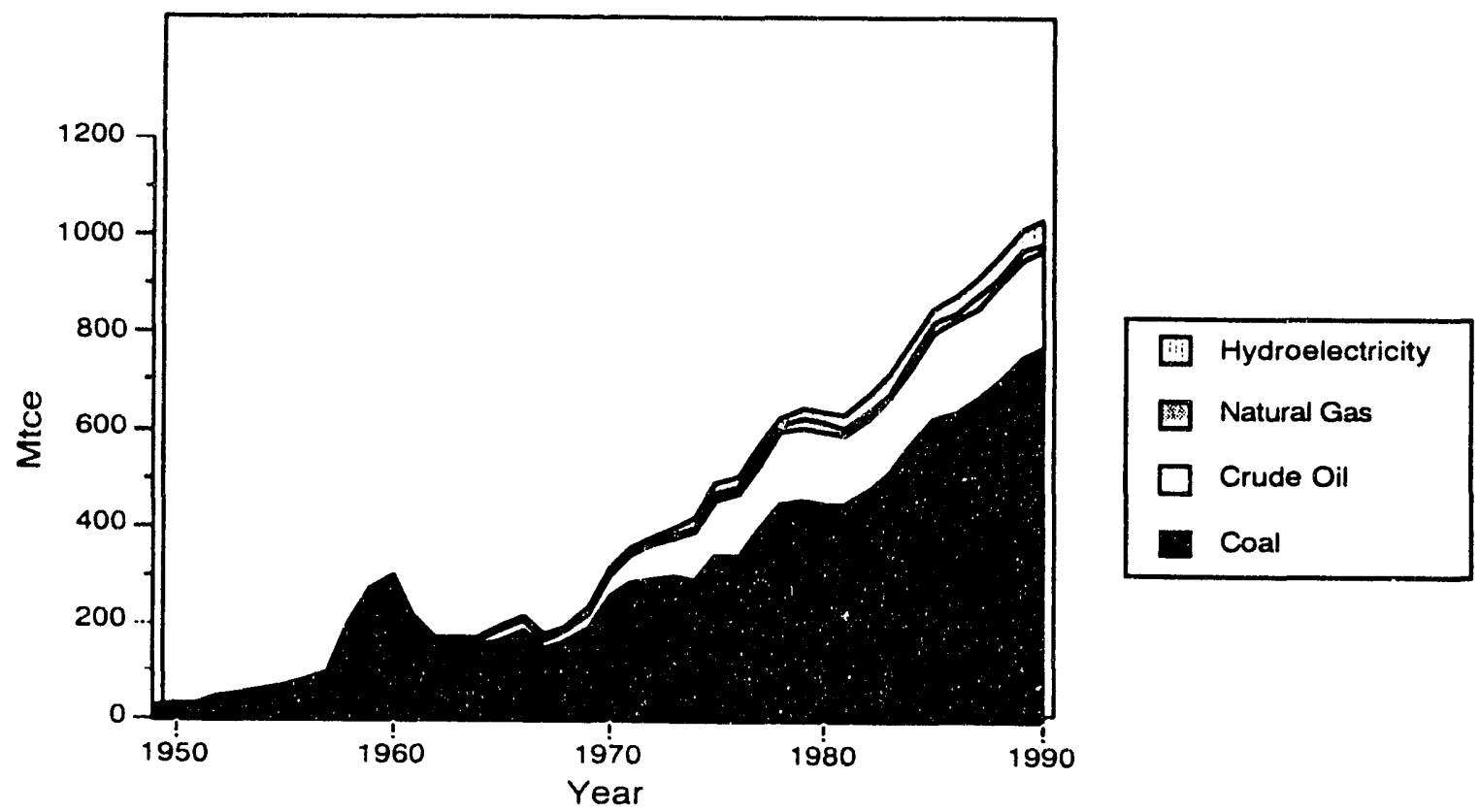

Source: Statistical Yearbook of China, 1991; Energy in China, 1990. 
Table II.2: Shares of Energy Production by Country and Source, 1988.

\begin{tabular}{cccccc} 
& Coal & Crude OII & Natural Gas & Hydropower & Nuclear \\
\cline { 2 - 6 } China & 700 & 196 & 19 & 43 & 0 \\
share & $73.1 \%$ & $20.4 \%$ & $2.0 \%$ & $4.5 \%$ & $0.0 \%$ \\
\hline India & 189 & 46 & 15 & 19 & 2 \\
share & $69.7 \%$ & $17.0 \%$ & $5.5 \%$ & $7 \%$ & $0.7 \%$ \\
USA & 756 & 623 & 621 & 84 & 205 \\
share & $33.0 \%$ & $27.2 \%$ & $27.1 \%$ & $3.7 \%$ & $9.0 \%$ \\
USSR & 463 & 892 & 886 & 80 & 61 \\
share & $19.4 \%$ & $37.4 \%$ & $37.2 \%$ & $3.4 \%$ & $2.6 \%$
\end{tabular}

Source: China/Energy Statistical Yearbook of China, 1989; India/Energy Indicators of Major Developing Member Countries, 1989; USA - Annual Energy Review, 1988; USSR/BP Statistical Review of World Energy, 1989.

Figure II.4: Net Energy Exports, 1950-1990.

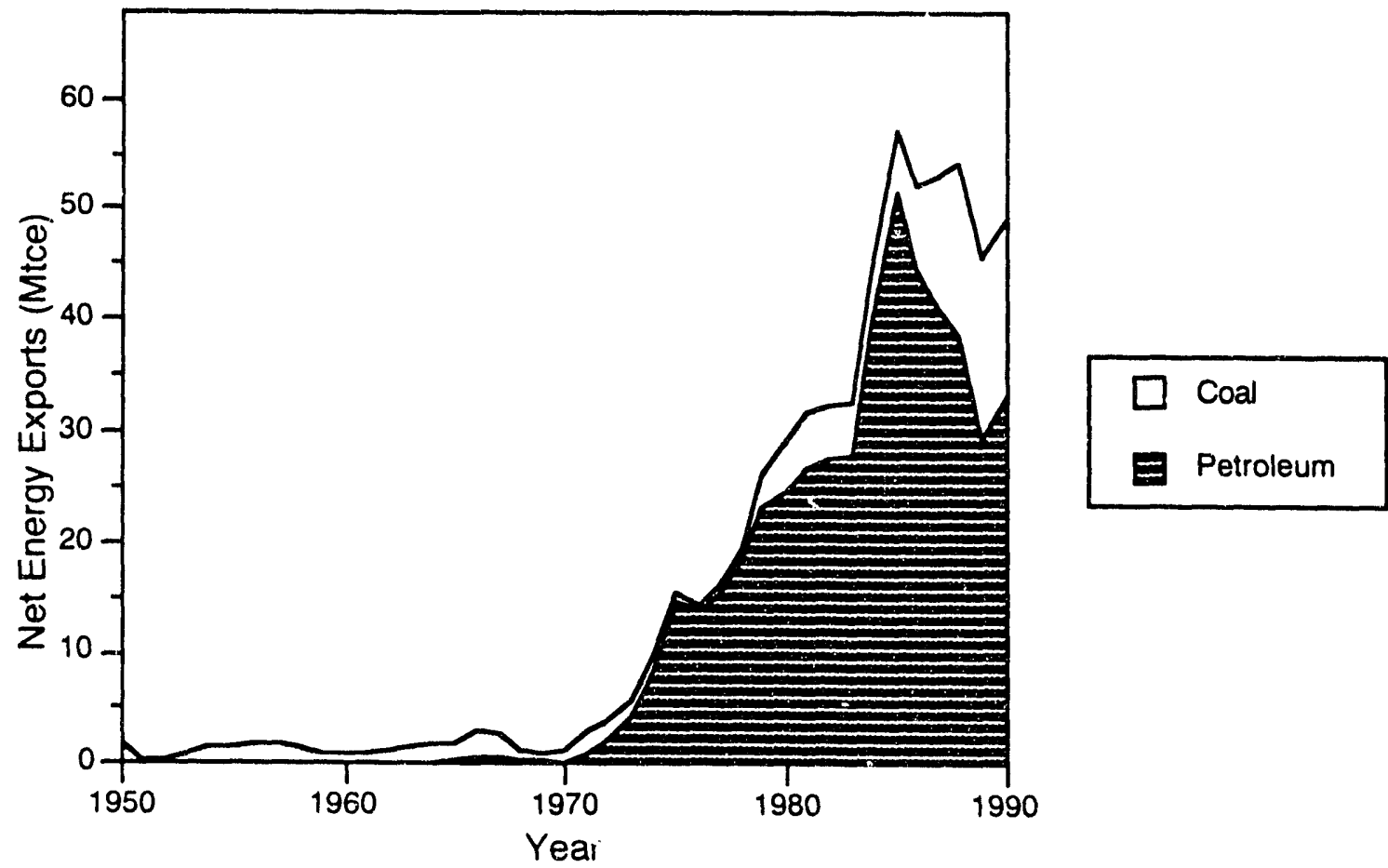

Source: Almanac of China's Foreign Economic Relations and Trade, 1984-1990/91; Chinese Customs Statistics. 


\section{COAL SUPPLY}

\section{Coal production}

Because of the overwhelming use of coal, the central issues in Chinese energy are related to coal supply and consumption. Total coal production has grown from 32 Mtons in 1949 to 1080 Mtons in 1990 ( 23 to 771 Mtce), at an average of $8.9 \%$ per annum, but at a slower rate in the later years, about $4.9 \%$ per annum since 1979 [State Statistical Bureau (SSB), 1991; Ministry of Energy (MoE), 1990].

Coal is obtained from three iypes of mines: central state-run, local state-run, and local collectives and private mines. The largest are owned by the China National Coal Corporation (formerly the Ministry of Coal Industry) under the Ministry of Euergy. Ministry mines produce about half of China's raw coal, and most of their output is distributed through rationing by the central government.

The second type of mine is state owned but locally supervised. The cutput of these smalland medium-sized mines is dedicated to meet loral demand. Their importance has been verwhelmed in recent years by rural collectives.

With the advent of economic reforms, collective and private mine ownership was introduced. The Chinese government has actively promoted these mines, owned by local groups, as a means of increasing coal production with minirnum state investment. Figure II.5 depicts output from these mines, which accounts for almost all the growth in coal production since 1978.

Rural collective mines are often very small, but nearly 80,000 have gone into production since ownership was allowed [MoE, 1989]. Mine output is sold on a spot market at prices usually higher than centrally produced coal.

Small rural mines have two advantages: they make use of small coal deposits not profitable for large-scale mining, and they employ the surplus labor in rural areas. Disadvantages include poor safety conditions and disorderly management, which destroys landscape and can ruin reserves suitable for larger scale mining.
Figure II.6 shows the shares of total output contributed by each type of mine.

\section{Coal quality and characteristics}

Bituminous coal mined in China generally has lower heating value than its US counterpart. Average Chinese commercial coal is rated at 0.714 tce/ton $(20.9 \mathrm{GJ} /$ ton $)$. Ash content is about $20 \%$. Information on the sulfur content of current coal production has not been released. From what we know about the characteristics of China coal reserves, commercial coal in China should have average low to medium sulfur content, in the range of $0.5-3.0 \%$. Coal mined in southern provinces, however, often has a very high sulfur content $(>4 \%)$. The output of all mines in 1988 consisted of $75.6 \%$ bituminite, $20.7 \%$ anthracite, and $3.7 \%$ lignite [MoE, 1989]. Compared to other countries, Chinese coals have a large percentage of anthracite. These coals generally have high ash/heat ratios and low to medium sulfur/heat ratios. Coking coals are so common they are often burned in applications that do not require them.

\section{Geographic distribution of coal mines}

Twelve out of the 14 largest mines (here a mine is actually a mining area with several adjacent single mines) with production greater than 10 million tons per year are all located in the north. Medium-sized mines are mostly located in the north, northeast, southwest and northwest. However, two of China's most important industrial areas are on the southeast coast and the northeast coast. Neither has adequate coal production to support its own needs. This pattern of coal mines and load centers has historically caused a large flow of coal from west to east and from north to south. Industries continue to develop along the seaboard, but transport facilities have not kept pace.

By the 1970s, increased coal traffic had already become a burden on the transportation system. Coal is the major shipment on all transport modes and accounts for about one third of the nation's total freighttransportation (ton-km). Forty-one percent of rail freight traffic (ton- $\mathrm{km}$ ), $21 \%$ of trucking traffic, and $20 \%$ of cargo traffic is coal. Of all transported coal, $67 \%$ goes by rail, $20 \%$ by highway, and $13 \%$ by water. China does not 
yet have any specialty transport modes like slurry pipelines. The average railway transport distance for coal in China was $500 \mathrm{~km}$ [Yearbook of Chinese Transportation, 1987].

Most outgoing coal is mined in Shanxi province. A transportation bottleneck has become a major barrier for the coal development of this area. It is estimated that Shanxi has stocked about 30 Mtons of coal at mine mouths in recent years [Wang, 1988]. The national total stockpile is as high as 50 Mtons. Coal shortages in the late 1980 s would have been less acute if transportation networks had been developed in a coordinated and timely fashion. Coal freight leaving Shanxi currently totals 200 million tons per year. Present railway construction projects will only accommodate 100 Mtons more, but the estimated coal freight out of Shanxi by the year 2000 is 500 Mtons, leaving a shortfall of $200 \mathrm{Mtons} /$ year transportation capacity [Ma, 1988].
One response to this formidable challenge is to build mine-mouth power plants, since it is presumably easier to transmit electricity than to transport coal. Unfortunately, northern provinces are generally short of the water resources required to wash the coal and meet power plant requirements. Coal washing and sifting also mitigate the transportation problem by reducing transport volume. Minemouth plants can also be tooled to use middlings from coal washing.

The transportation problem can be addressed in many different manners, each with its attendant advantages and disadvantages. The successful resolution of this issue is vital to China's economic well-being, and merits careful attention and further study.

Figure II.5: Raw Coal Production by Type of Mine, 1950-1990.

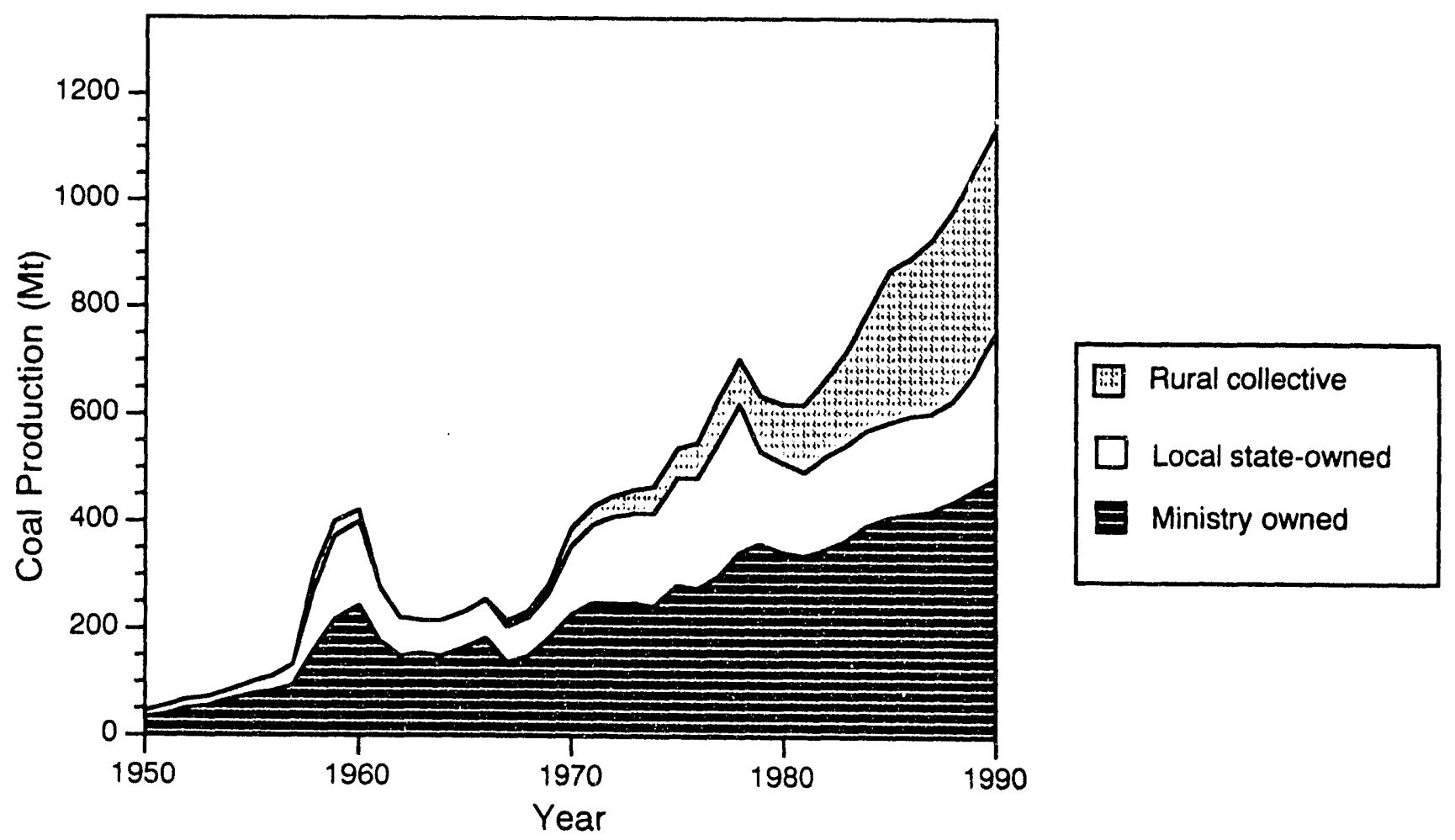

Source: Yearbook of China's Coal Industry, 1982-1988;Energy in China, 1990; China Statistical Yearbook, 1991. 
Figure II.6: Coal Production Shares, 1950-1990.

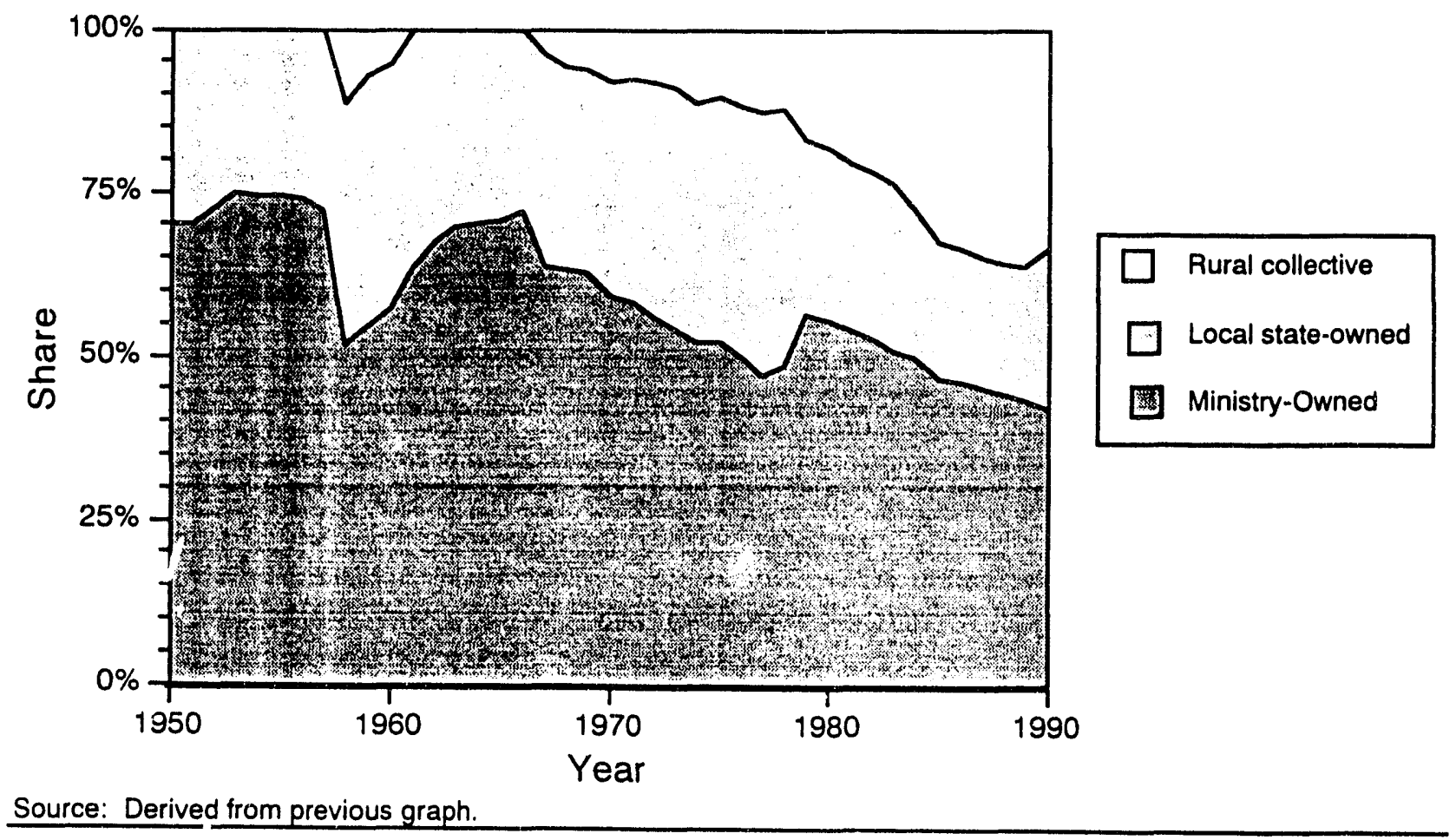

\section{Coking coal}

Of the 793 Mtons of bituminous coal mined in $1988,63.0 \%$ was coking coal $(47.4 \%$ of total coal production) [MoE, 1990]. Data for 1988 show that only 89 out of 463 Mtons of coking coal was used for coking. Non-coking usage of coking coal must be substantial. This imbalance occurred because China has always emphasized the development of its steel industry, seen historically as the cornerstone of Chinese industrial development. A primary goal of coal mine development had been to provide coking coal to the steel industry. The growth of steel pro 'uction was overestimated, and coking coal mining overdeveloped in anticipation. Transportation lines and consumers also located near the coking coal reserves, so, once developed, these mines continued to produce even though their output was not well matched with end-uses. Coking coals reserves are relatively rare, and their use as boiler fuel is not desirable. They also cause more air pollution because of a higher proportion of volatile organic compounds than ordinary bituminous coal.
To stop the overuse of coking coals, reserve management should be strengthened and the development of other types of bituminous coal needs to be emphasized. The present surplus of coking coal could be exported, as long as future self-reliance is not impaired. Exporting is dependent on increasing coal-washing capacity, however, because of the high ash content of China's coking coal.

\section{Mine conditions}

Mining conditions are unfavorable in China compared to the US or USSR. Seams are thinner, and mines are more remote, less well equipped, and more dangerous.

Seam thickness. Ascertaining the average thickness of the seams mined in China is difficult because tiny rural mines are included in the figures. From ministry-owned mines $11.6 \%$ of output is mined from seams thinner than $1.3 \mathrm{~m}, 42.8 \%$ comes from seams of $1.3-3.5 \mathrm{~m}$, and $45.6 \%$ is mined from seams thicker than 3.5 $\mathrm{m}$ [1983 data, Wang, 1988]. US average thickness in 1986 was $4.8 \mathrm{~m}$, largely due to thick coal beds in surface mines [DOE/EIA, 1986]. 
Mining technology and labor productivity. Coal mining is less mechanized in China than in the developed world, but efforts are being made to close the gap. In 1988, 58\% of ministryowned mines had mechanized underground extraction, and $31.4 \%$ had fully mechanized mining processes [MoE, 1989]. Mechanization in locally supervised mines is at a much lower level, and in rural mines, manual extraction is the rule. Due to these factors, the labor productivity in Chinese mines is quite low. In average ministry-owned mines, 1.1 tons are mined per miner-shift, and this figure would be considerably lower if rural mines were included [MoE, 1989]. In US mines, the average is 23 tons per miner-shift, largely due to the high labor productivity of surface mining [DOE/EIA, 1986].

\section{Surface mining}

Most of China's coal deposits are deep underground. Production from surface mines is only $4 \%$ of total production, compared to $60 \%$ in the US and $40 \%$ in the USSR [Ma, 1988]. Surface mine projects are tavored because they are less capital-intensive and have a shorter lead time before they begin producing. Five surface mines have been under development, with a total projected annual output of 218 Mtons (113 Mtons is lignite). If these projects are completed on time and meet expected capacity, the ministry's goal of increased coal production should be met without difficulty. With these projects, Inner Mongolia will become an important supplier, and lignite production will increase.

China has limited experience with surface mining and could use foreign technical assistance. The good quality of some of the strip-mined coal makes it an attractive export and increases the potential for profitable joint ventures with other countries. But a large joint venture project, the Antaibao surface mine, with Occidental Petroleum has run into considerable difficulty [Weil, 1991].

\section{Coal washing}

Coal washing is an important area for development in China. Present coal-washing capacity is 190 Mtons per year in 1988, with 170 Mtons actually washed [Energy Statistical
Yearbook of China, 1989]. About 70\% of washing capacity is devoted to coking coal for the steelmaking industry [MoE, 1989]. Only $17 \%$ of Chinese coal is washed, compared to $42 \%$ in the US [1980 data, Wang, 1988]. More than $80 \%$ of Chinese coal is consumed with little treatment. Untreated coal is th.crmally inefficient, environmentally damaging, and imposes an unnecessary additional transportation burden.

Development of coal-washing facilities has been hindered by several factors, especially the very large capital requirements, and also the production of middlings (low heat-value leftovers), which are difficult to dispose of. The cost of coal-washing facilities should be compared with the benefits: reduced coal transport costs, more efficient end-use combustion, reduced pollution, and increased foreign exchange earnings. Because of the tradeoffs involved, the resolution of this issue will be empirical. More detailed study is recommended.

\section{International trade and financing of coal projects}

In 1986, 320 Mions of coal were traded internationally. Of this, China accounted for only $3 \%$, comparzd with $26 \%$ for Australia, $24 \%$ for the US, and $13 \%$ for South Africa [Yearbook of China's Coal Industry, 1987]. This small share is disproportionate with China's 23\% (and rising) share of world coal production and the good quality of Chinese coal.

Given its huge reserves, China has the potential to become a major coal exporter. Japan would likely be the main purchaser since it is the world's largest coal importer, and currently the biggest buyer of Chinese coals. Still, Chinese coals presently account for less than $10 \%$ of Japan's imports. Japan has a large need for coking coals, so expanding the Japanese market for surplus Chinese coking coal could be mutually beneficial. However, the high ash content of Chinese coal makes it less desirable than coking coals from other sources. China needs expanded coal-washing facilities in order to inprove its competitiveness in the international coal market.

Another major coal importer in Asia, China's critical market, is South Korea. As is the case 
with Japan, China must focus on quality improvement if it is to win market share from its main regional competitor, Australia.

While the European Communities are major coal importers, transport distances will continue to favor coal from the US and USSR.

Since coal is vital for China's economy, coordinated planning of exports and domestic supplies is necessary. Shanxi and Inner Mongolia hold the highest quality reserves most suitable for export. These areas also supply most of the domestic demand. A large increase in export coal will therefore compete with the washing, transport, and use of coal for domestic consumption. The need for hard currency might tempt planners to allocate the lower quality coal to domestic uses. In providing cleaner coal for export, China should be cautious of exacerbating air pollution by burning dirtier coal domestically.

In conclusion, developing the coal processing infrastructure provides the largest challenge to the future development of China's coal industry. Transportation, as well as coal washing and sorting, must be developed simultaneously with mining capacity.

\section{Future development of coal supplies}

Planned coal production by the year 2000 is 1400 Mtons [People's Daily, 1/25/89]. Compared with the 1988 production of 980 Mtons, the planned figure will require a growth rate of $3.0 \%$ per annum. Of this 1400 Mtons, ministryowned mines are planning to produce 700 Mtons, making up $63 \%$ of the absolute increase (up from 435 , at a $4.0 \%$ annual rate of growth). About 40 Mtons of present ministry-owned capacity will become nonproductive by 2000 [Economic Information Agency, 1988]. The costs of this capacity increase, including transportation infrastructure improvements, are 215 yuan per annual ton in 1985 [Levine and Xueyi, 1990]. For the projected 295 Mtons per year capacity increase, assuming a cost today of about 300 yuan per annual ton, 7.4 billion yuan per year for 12 years is required. ${ }^{1}$ Compared with the 5.95 billion yuan invested in exp ding coal production in 1987 (excluding rural itines), this

1 Constant marginal cost is assumed. Strip mining costs could be lower. Discounting is not applied. goal is within the realm of feasibility. However, the expansion in coal output will require the development of attendant (e.g., transportation) infrastructures at an additional cost to bring coal to market and to utilize it efficiently.

The most recent effort to boost coal production is the key project of the Eighth Five-Year plan (1991-1995)-the construction of the ShengfuDongsheng mine. This mine, located across Shanxi province and Inner Mongolia, is the largest in China so far, with proven reserves of 230 billion tons (this figure is not comparable with the western definition of recoverable reserves). The quality of coal from this mine is among China's best, with an average heating value over $25 \mathrm{GJ} /$ ton, sulfur content lower than $1 \%$, and ash content around $10 \%$. The planned steam coal production for this mine is 60 Mtons/year by 2000 . The near-term (1995) goal is $30 \mathrm{Mtons} /$ year [People's Daily, Overseas Edition, 6/8/91].

With the development of the ShengfuDongsheng mine and the other five large surface mines (with total eventual production capacity of 280 Mtons) big mines will become China's major coal suppliers and coal production will become more concentrated in north China in the next century.

Two hundred seventy Mtons per year of production, or $18 \%$ of the absolute increase (up from $195 \mathrm{Mt} /$ year, requiring an annual $2.7 \%$ growth rate) are assigned to local state-owned mines. Four hundred thirty Mtons annual output is expected by 2000 from rural mines, or $19 \%$ of the increase (up from $350 \mathrm{Mt}$, an annual growth rate of $1.7 \%$ ). These figures also are practical considering the recent performance of these mines, so 1400 Mtons of coal production by the year 2000 is an achievable goal, if the resources are made available and if infrastructure is also developed in parallel.

\section{E. PETROLEUM SUPPLY}

\section{Oil production}

The development of the Chinese oil industry in the 1960s and 1970s allowed China to achieve energy autonomy and encouraged growth in subsidiary industries. The petroleum industry 
is less prosperous now; production growth is very slow, and discovery of new reserves is limited. Demand for petroleum, however, is continuing to increase. The future performance of China's petroleum industry will have a great impact on China's continuing development.

Since the discovery of the Daqing oil field in 1959, the petroleum industry has made impressive progress. Crude oil production reached 134 Mtons in 1990, ranking China fifth in world figures following the USSR, the US, Saudi Arabia, and Mexico. The period of most rapid expansion occurred between 1968 and 1976, when production grew from 110 to 611 $\mathrm{Mbbl} / \mathrm{yr}$ (21 to $119 \mathrm{Mtce})$, an annual growth rate of $23.9 \%$. This growth can be seen in Figure III.7.

Leveling off of output from Daqing since 1976-77 has had the greatest impact on slowing the growth trend. Great efforts to increase production have been made in smaller fields (Liaohe and Shengli). Continued increases from these fields, however, are uncertain, and production from Daqing will likely decline in the next ten years. China's petroleum industry is in a critical period, and future development will depend on new findings and capital investment to support exploration and development.

\section{Production characteristics of Chinese crude}

China's oil reserves have two prominent features: the crude is heavier than that found in other oil-rich areas, and the reserves are formed in complex geological structures. For the most part, Chinese crude oil occurs in relatively thin and small reservoirs and at low pressure. For this reason, water injection has to be widely used in the early stages of production. About $90 \%$ of China's crude is produced this way [Wang, 1988]. The higher density of Chinese crude also reduces pressure and requires earlier secondary extraction. Low pressure and small reservoirs combine to push China's recovery rate down to an average of 27\% [DOE/EIA, 1987]. Despite these disadvantages, production costs are still quite low. Daqing production is as low as $\$ 4.00$ per barrel at the 1986 official exchange rate [DOE/EIA, 1987]. These low costs are attributed to lower labor costs and cheaper, less sophisticated equipment.

\section{Geographic distribution of oil fields}

The geographic distribution of oil fields is similar to the distribution of coal mines. Most major basins are in the north. There are eight major onshore oil fields and tens of smaller fields. In 1987, the eight major fields produced $94 \%$ of China's crude [Yearbook of China's Economy, 1988]. Seven of China's eight top oil fields are either near or within industrial areas. The bulk of the proved reserves is conveniently close to transportation centers.

Daqing is near Liaoning province, China's heavy industry center; Shengli and Liaohe are both near the coast, within easy reach of shipping lines to eastern industrial centers like Shanghai and Jiangsu province. Northern industrial centers, Beijing and Tianjin, also have the Huabei and Dagang oil fields nearby. The result is that there is no intensive oil transport in China.

\section{Offshore oil}

Offshore prospecting started in 1965 but did not make much headway until 1979, when China turned to western capital and technology for this risky business. After ten years, the future of offshore oil in China is still uncertain. Production in 1987 was 714 ktons: 315 ktons from a Sino-Japanese joint venture in the Chengbei oil field in the South China Sea, $\mathbf{3 5 2}$ ktons from a joint Sino-French venture in the South China Sea, and $47 \mathrm{ktons}$ from a self-managed platform in the Bohai Sea. By 1990, offshore production had only doubled, to $1.43 \mathrm{Mt}$.

\section{Refineries}

By 1988, China had 33 medium and large oil refineries, with a total capacity of 126 Mtons. In 1988, 101.6 Mtons were processed with the following output: 18.66 Mtons gasoline (22.2 Mtce), 24.42 Mtons diesel (35.58 Mtce), 5.25 Mtons kerosene (6.72 Mtce), 1.83 Mtons lubricants, 28.17 Mtons heavy oil, and 7.2 Mtons other products [MoE, 1989]. 
Figure 11.7: Crude Oll Production by Field, 1950-1990.

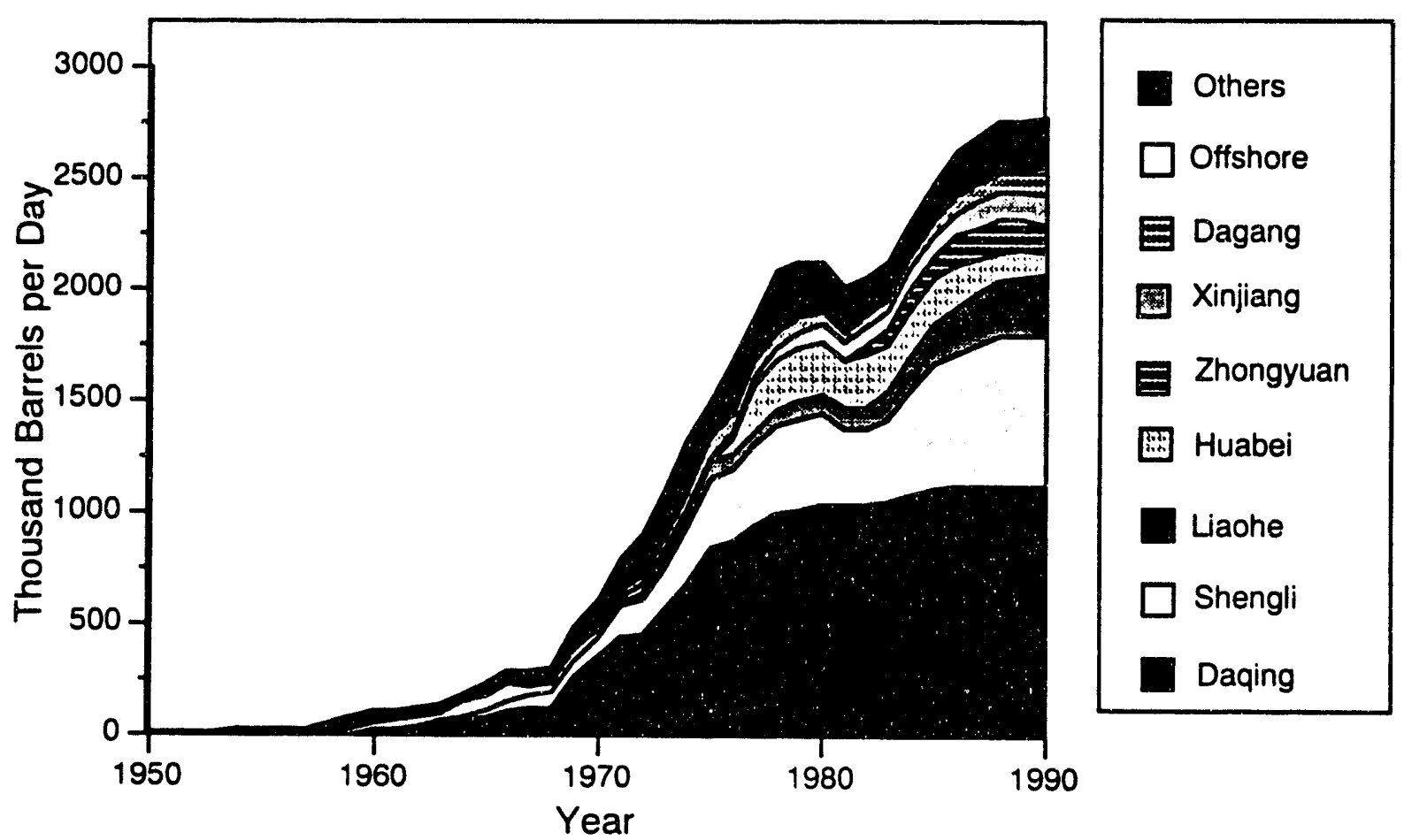

Source: The Petroleum Resources of China, DOE, USA, 1987; Yearbook of China's Economy, 1988.

Higher residue content and low gasoline content are general characteristics of Chinese crude. However, the low gasoline recovery of $18 \%$, compared to $49 \%$ in the US, is in part due to lack of technical sophistication in refining equipment and methods [MoE, 1989].

One interesting recent development is that China has decided to use money from France to build a joint-venture refinery with a capacity of 5 Mtons/year upon completion in 1994. All crude oil for this refinery will come from the Mideast and $70 \%$ of the products will be exported [People's Daily, Overseas Edition, $7 / 5 / 91]$.

\section{Oil exports}

The development of the Daqing oilfield terminated China's oil dependency in the late 1960s. Oil exports have grown steadily since 1970 and peaked at 38 Mtons in 1985 [SYC, 1989]. The time path of this export is shown in Figure II.8.
Oil exports have declined since 1985 because of increasing domestic consumption and declining world oil prices. Oil exports account for about one-quarter of China's total crude production, and the earnings from oil exports were about $8 \%$ of China's total foreign earnings in 1988 [SYC, 1989]. Exports are maintained at the expense of the domestic market. The goal of maintaining reserves of foreign currency has conflicted with provision of adequate domestic oil supplies. The pressure to decrease exports will grow because of increasing domestic consumption.

\section{Future oil production prospects}

The biggest threat to China's oil production is the possibility of Daqing's decline. Production began to level off in 1978 and has since remained constant. In order to maintain a 50 Mton annual output, oil layers as thin as 0.2-0.5 meters have been drilled. To date, more than $50 \%$ of recoverable reserves have been extracted [Yearbook of China's Economy, 1988]. The remaining reserves have an average water 
content of $70 \%$ due to past secondary recovery methods. Output from old drilling areas has decreased. Prospecting for new reserves in outer areas of old fields has been vigorous in recent years, but findings are still limited. Considering standard production profiles, Daqing's production will decline, probably soon, given the above indicators. Figure II.9 depicts this trend.

Other important fields are also waning. Huabei, once the third largest oil field with an annual production of 15 Mtons (23 Mtce), has witnessed an annual decline of 2 Mtons ( 3 Mtce) in recent years. Only two of the major oil fields may have the potential to appreciably expand their production. Shengli was once projected to produce 50 Mtons ( $77 \mathrm{Mtce}$ ), a very ambitious goal given its recent performance. Liaohe is also favored by the government for development, producing 11.3 Mtons (17.3 Mtce) in 1987.

The official projection is for a 200-Mton (306 Mtce) total by the year 2000, a total which will be difficult to achieve even if Daqing maintains its production of 50 Mtons per year until then. Therefore, new fields will be very important in this drive to increase production.

There are three potential sources of new reserves. The first is the outer areas of old fields. Increases in reserves in recent years have come mainly from these sources. The second is offshore fields, development of which is still in its incipient stages, and which will contribute the least even if it is fully developed. The third and most promising is a discovery in the Talimu basin, China's largest sedimentary basin, in western Xinjiang. Here geological conditions, coupled with marine sediments and a low underground temperature gradient, indicate the presence of new fields. Many large, possibly oil-bearing structures have been found. Experts estimate as much as 18.45 Btons of probable in-place reserves, or about 5 Btons ( $7.7 \mathrm{Btce}$ ) of recoverable reserves [MoE, 1988]. This figure is greater than present total proved reserves (3.2 Btons) estimated by the EIA.

Figure 11.8: Petroleum Exports, 1970-1988.

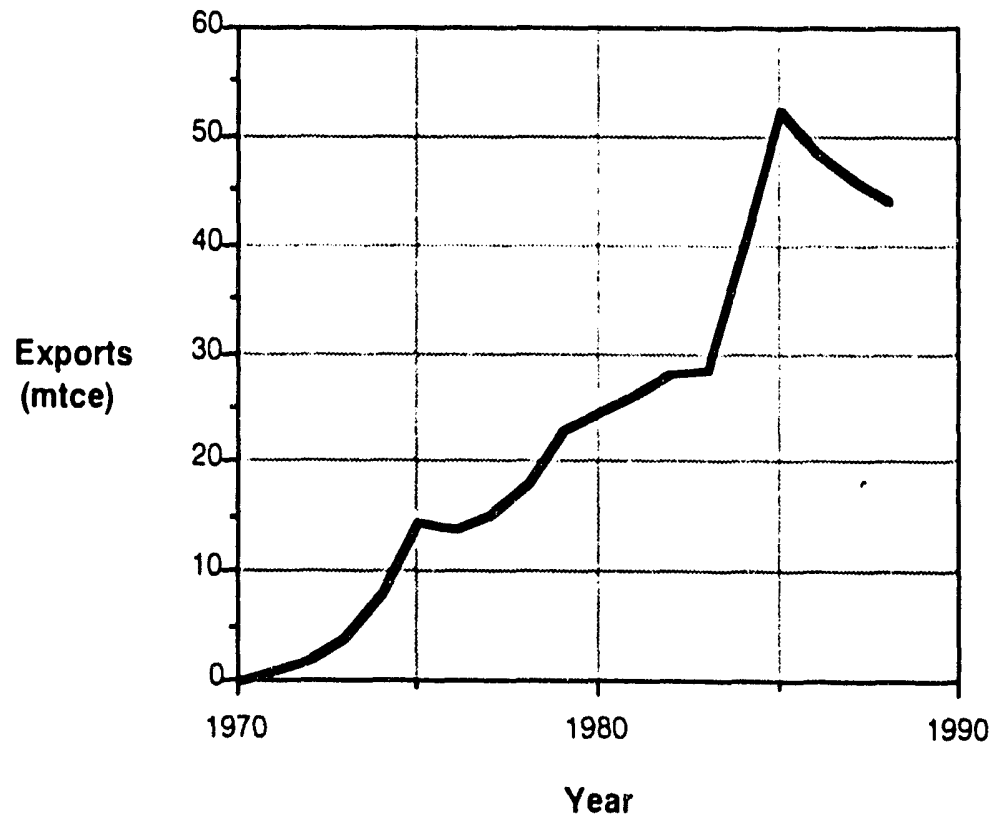

Source: See Figure 11.4. 
Figure II.9: Crude Oil Production Growth Rate, Daqing Oilfield, 1961-1987.

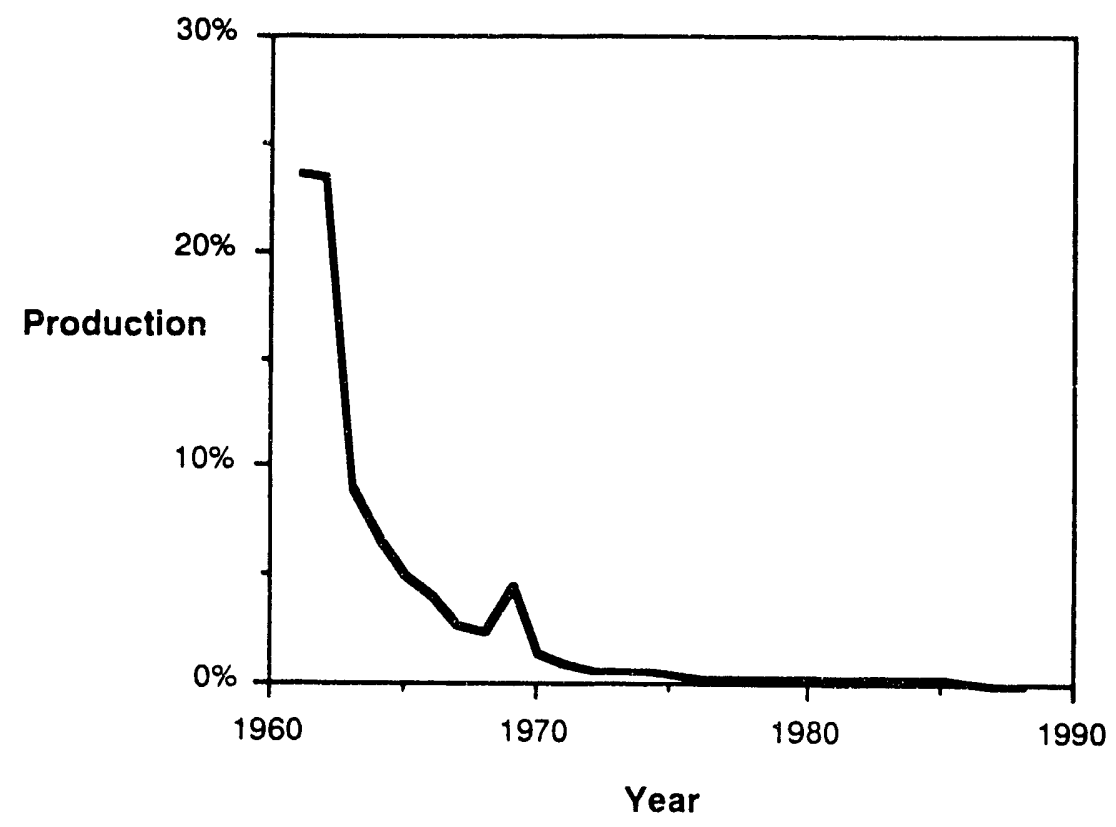

Source: Derived from data in The Petroleum Resources of China, DOE, USA, 1987; the Yearbook of China's Economy, 1988.

The Chinese are hoping the Talimu basin will be a second Daqing oil field. Although western technologies may be vital for Talimu's development, the government has decided to use only domestic technology and capital. In order to speed development, the state council has recently approved a $\$ 1.2$ billion loan to the China National Oil and Gas Corporation (formerly the Ministry of Petroleum) through the Bank of China [People's Daily, Overseas Edition, 6/29/91]. The government considers the development of Talimu oil a strategic priority for China's economy. The Talimu basin represents probably the greatest hope for a significant increase in onshore oil reserves. If the hope is well founded, China's petroleum industry will be able to take advantage of another period of prosperity.

In general, however, the petroleum industry lacks resources, both human and capital, to develop new capacity. At present, most resources must be used for maintaining present production quotas. Very little is left for prospecting despite the fact that decreasing reserves leave fewer backups for production. Investments in prospecting are necessary. Such investments cannot guarantee a resurgence of the oil industry in China, which depends on the quality and quantity of recoverable oil resources, but without it, the Chinese oil industry will surely decline.

\section{F. NATURAL GAS PRODUCTION}

Natural gas production in China is very small compared to other countries. In 1988, $14.2 \mathrm{bcm}$ was produced, compared with a production of $446.1 \mathrm{bcm}$ in the US in 1987 (18.7 and 589 Mtce respectively). Natural gas production has stagnated in the last decade, failing to regain its peak of $14.5 \mathrm{bcm}$ achieved in 1979 . Increasing natural gas production is of great interest to the Chinese because it could substitute for coal in all end-use sectors, especially in the residential sector.

Fields in Sichuan province provide $40 \%$ of China's natural gas. Most of the rest is from the three top oil fields. Since oil and gas are often co-products, more associated gas production is expected. Chinese gas:oil output ratio is $0.12: 1$, compared to about $1: 1$ for the US and the USSR. ${ }^{2}$ This low ratio is not thought to

\footnotetext{
${ }^{2}$ Derived from British Petroleum data.
} 
be the result of fewer natural gas reserves, but rather may be a consequence of an emphasis on oil development that has delayed natural gas prospecting. Gas development requires more sophisticated technology and is more capitalintensive than oil. China lacks expertise and experience in natural gas prospecting, and would benefit from foreign technical assistance in this area.

In order to strengthen the development of natural gas, an individual department of gas has been established under the former Ministry of Petroleum. Under this new arrangement, gas prospecting will be separated from oil prospecting, and natural gas development will have a separate budget.

Production projections are for $30 \mathrm{bcm}$-double present production-by the year 2000 .
Recently, several promising developments have indicated that this target may be attainable. Prospecting around old oil fields has revealed reserves, and a large offshore field was discovered in the South China Sea. A field expected to yield $3.5 \mathrm{bcm}$ when completed is scheduled to begin development next year [People's Daily, 10/16/90]. Recently (6/21/91), the Xinhua News Agency announced that in the northwest Shaanxi-Gansu-Ningxia basin exploration has located China's largest natural gas field so far. It is also reported that a feasibility study of a $3 \mathrm{bcm}$ pilot is under way. No further details have been disclosed. Also, Canada is working with China to develop Sichuan's gas fields. Still, present reserves are very limited and will require additional investments in infrastructure to bring to market.

Figure II.10: Electricity Generation, 1950-1988.

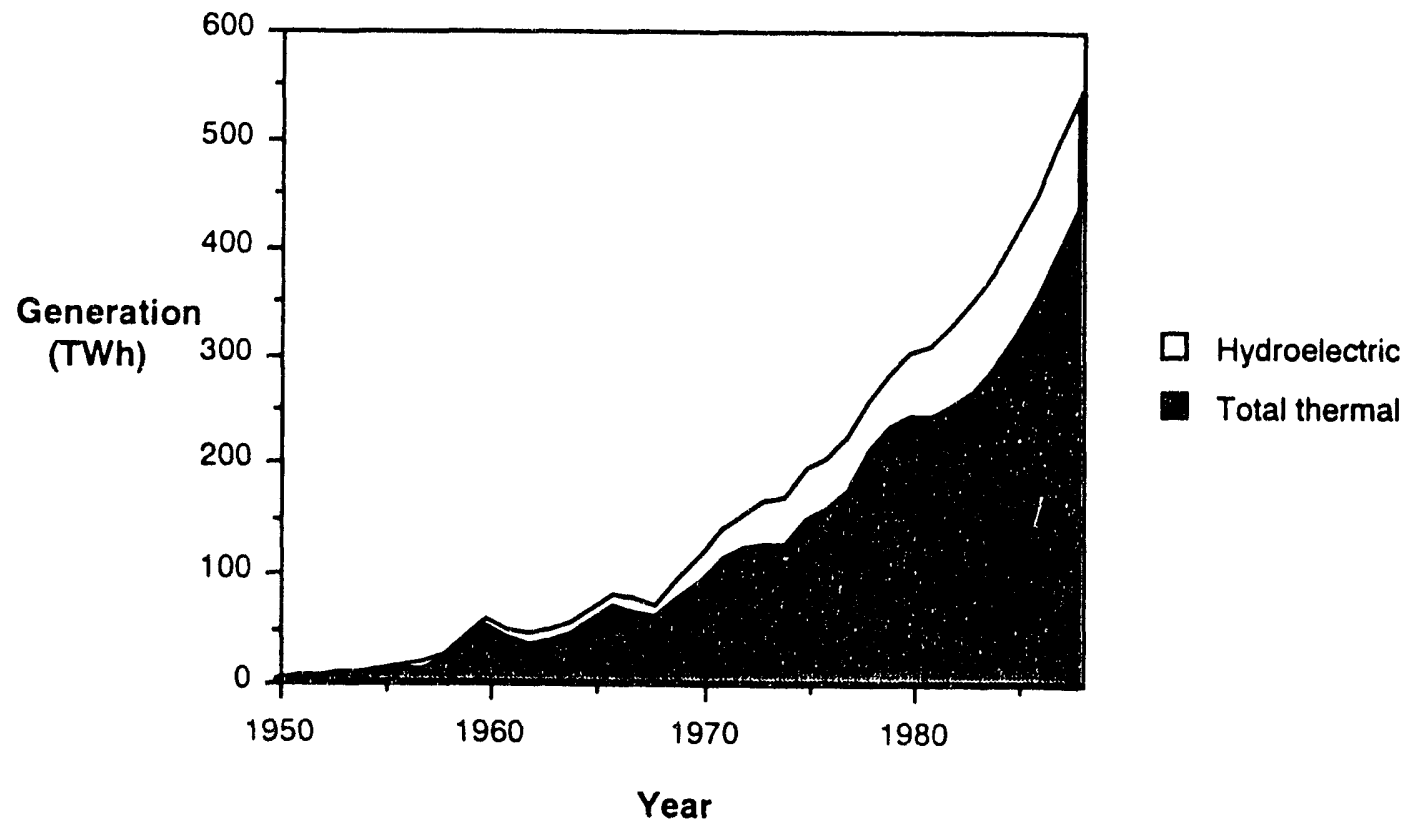

Source: Energy in China, 1980. 


\section{G. ELECTRICITY SUPPLY}

\section{Electricity generation}

The electric power industry has always enjoyed rapid growth. From 1950 to 1988 the average annual growth rate was $11.5 \%$ and $13.4 \%$ for installed capacity and electricity generation respectively. Growth rates in recent years have actually been accelerating. Total installed capacity was $115.5 \mathrm{GW}$ in 1988 , of which $32.7 \mathrm{GW}(28 \%)$ was hydro, and $82.8 \mathrm{GW}$ $(72 \%)$ thermal [MoE, 1989]. Total electric generation reached 545 TWh in 1988, ranking fourth after the US, the USSR and Japan. Of this, $81 \%$ or 439 TWh was thermal generation, and the remainder hydroelectric. Figure II.10 shows electricity generation over a nearly 40 year span. At present there is no on-line nuclear capacity, although $2100 \mathrm{MW}$ of capacity is under construction.

\section{Thermal generation}

As mentioned previously, thermal power plants supply most of the electricity in China. In 1988, 436 TWh (about $80 \%$ of the total electricity generated) were generated at thermal stations. Thermal electricity generation consumed 168 Mtce of fossil fuels, of which $86.6 \%$ was coal, $11.5 \%$ was petroleum, and $0.7 \%$ natural gas [MoE, 1989]. Relative to other countries, the coal share is high and the natural gas share is very low. Comparable figures for the US are $78.3 \%, 6.5 \%$, and $15.2 \%$ respectively [DOE/ EIA, 1988].

Chinese thermal plants are still small. As of the end of 1988, there were only 10 plants with installed capacities larger than $1 \mathrm{GW}$. (This number will increase to 15 when pending projects are completed) [MoE / MWR, 1989]. By 1988 , only $34 \%$ of thermal capacity ( $28 \mathrm{GW}$ ) was from units with $200 \mathrm{MW}$ or greater capacity [MoE/MWR, 1989]. The majority of thermal units are less than $100 \mathrm{MW}$.

Medium- and low-pressure and temperature units still compose $20 \%$ of thermal capacity [ESYC, 1989]. These inefficient units reduce conversion efficiency in China to about $27 \%$, compared to about $33 \%$ in the US (in China, pollution control is still minimal). In 1988, average unit energy consumption for net electricity generation was $0.431 \mathrm{kgce} / \mathrm{kWh}$, compared to $0.377 \mathrm{kgce} / \mathrm{kWh}$ in the US 3 . This difference indicates a large savings potential if plants were modernized. Table II. 3 gives more information on fuel efficiencies of different units.

Capacity factors are very high for Chinese thermal generators: 0.60 (capacity factors of major grids are even higher, for example, over 0.70 for the East China Grid [SSB, 1989a]) vs. 0.42 in US. This reveals that China's backup capacity is inadequate. Since the 1960s, the increase in installed capacity has lagged behind the increase in demand, requiring that existing units be run longer hours, resulting in more and more interruption.

Geographic distribution of thermal generation. Most of China's installed thermal capacity is located in load centers. Seventy percent of the total thermal capacity is located in eastern, northeastern, and northern provinces, near either industrial centers or coal resources. These regions have only $7 \%$ of the nation's hydro resources. Influenced by the distribution of coal resources, future construction of large thermal power plants probably will be in these areas, especially the north, because of the newly found interest in mine-mouth power plants.

Future of thermal generation. In 1985, there were 18 major new or expansion thermal projects under construction. Total capacity is 10,925 $\mathrm{MW}$, with $7000 \mathrm{MW}$ in mine-mouth units. Turbine size is usually $200 \mathrm{MW}$ or $300 \mathrm{MW}$; there are only three $600 \mathrm{MW}$ units in China [Wang, 1988]. Bigger generators and minemouth locations represent the current trend in China's thermal power development. Tentative plans include the construction of $\mathbf{3 0}$ GW of mine-mouth thermal power capacity in the next 10 years [People's Daily, Overseas Edition, 4/2/91].

\section{Hydropower generation}

China is rich in hydropower resources, but most still remain to be harnessed. In 1988, installed hydropower capacity was $32.7 \mathrm{GW}$, or about

\footnotetext{
3 Power plant self-use is netted out in this measure.
} 
Table 11.3: Fuel Efficiency of Domestically Manufactured Thermal Power Units.

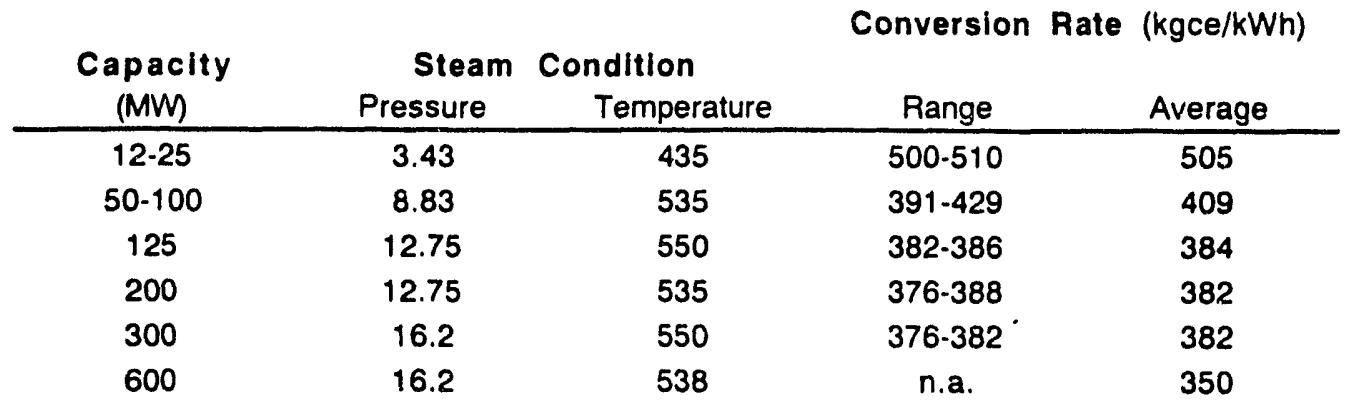

Source: Electric Power Industry in China, MoE/MWR, 1989.

$8.6 \%$ of the total exploitable hydro reserves [MoE, 1989]. This figure contrasts with the over $30 \%$ ratio of installed hydropower to exploitable capacity in the US and USSR.

Because of technical obstacles, the development of large hydropower projects did not begin in earnest until the late 1960s. As a result, China has a large share of small hydropower projects. A full $37 \%$ of its hydro capacity is smaller than $25 \mathrm{MW}$, and $22 \%$ is between 25-250 MW [Wang, 1988]. This large share of small hydro projects in installed capacity is unique to China. Because small hydro is more susceptible to flow variations, the average capacity factor of hydropower in China was a low 0.38 in 1988 [derived from data in SSB, 1989a].

Geographic distribution of hydropower generation. Hydropower resources are located mainly in the south, southwest, and northwest. In these areas, hydroelectricity generally composes about $50 \%$ of total electric generation. The Yangzi River has the largest potential for development. Including tributaries, the exploitable hydro resources in the Yangzi River basin are $197.2 \mathrm{GW}$, or about $50 \%$ of China's total. Most superlarge sites (with capacities greater than $2 \mathrm{GW}$ ) are located in the upper reaches of the Yangzi. The development of these hydro resources in the near future is unlikely because of capital constraints and technical obstacles. So far, only one such station has been constructed, Ge-zhouba, with 2.715 GW installed capacity [MoE, 1989].

The Yellow River, China's second largest river with $28 \mathrm{GW}$ of exploitable resources, has been more extensively developed. Five large (250 MW and above) hydropower stations are now located in the upper middle reach of the Yellow River. A sixth is under construction. Together they will have a total capacity of $\mathbf{3 . 3}$ GW [Wang, 1988].

The construction of hydro projects has moved south in recent years. Of the 13 projects presently under construction, 10 are in southern or southwestern provinces. On completion, these projects will add an additional 15120 MW of installed capacity, or about 50 TWh yearly (with a 0.4 capacity factor) [MoE / MWR, 1989].

In the next 10 years, China's hydropower development will be concentrated in the southwest (including Sichuan, Guizhou, Yunnan, and Guangxi provinces). The Ertan hydropower station, currently under construction on the Yalong river in Sichuan, has 3.3 GW installed capacity, which makes it the largest in China so far. Planned investment for this dam is 10 billion yuan, of which $40 \%$ will come from foreign loans. It is estimated that the exploitable hydropower resources of the Yalong river is about $25 \mathrm{GW}$. The construction of the Ertan hydro power station will be a critical test of China's ability to build a large dam in the remote southwestern mountains, where China's richest hydro resources are located [People's Daily, Overseas Edition, $7 / 10 / 91]$.

4. Nuclear generation

China is about to place its first nuclear reactor on line. The Chinese government has shown a special interest in nuclear power in recent years 
because its use offers a "clean" replacement for coal, reducing air pollution, and would ease the strain coal puts on the transportation systems. Several projects are underway. A domestically designed $300 \mathrm{MW}$ pressurized water reactor (PWR) is expected to come on-line this year on the coast near Shanghai. Two $900 \mathrm{MW}$ PWRs were imported in 1984, one each from the US and France. Both are expected to be operational near Hong Kong by 1992 or 1993. Another project with two $600 \mathrm{MW}$ PWRs has been approved for construction, with the intention of acquiring experience building the $600 \mathrm{MW}$ units. The government also intends to build a plant in northeastern Liaoning province and maybe another near Shanghai, for which detailed information is still unavailable.

Public concern about the dangers of nuclear generation has no avenue for expression, and the electricity is sorely needed, so political opposition is expected to be negligible. The main obstacle is investment requirements. Domestic nuclear power stations are reported to be four times more capital-intensive than comparable coal-fired plants [Hung, 1989]. Imported reactors are even more costly.

The lack of technical expertise will also hinder the development of the nuclear industry. China may not have the indigenous capability to provide some of the needed training. The availability of domestic uranium resources is also in question. Present proved resources are only enough to fire $15 \mathrm{GW}$ of PWR generating capacity for 30 years [Wang, 1988].

\section{Electricity transmission}

China now has 13 major electricity transmission grids, with a total installed capacity of 102.8 GW as of 1988 . By the end of 1988 total circuitlength of overhead transmission line was 426 thousand $\mathrm{km}$. The majority of the transmission lines are $35 \mathrm{kV}$ to $110 \mathrm{kV}$. Lines of $300 \mathrm{kV}$ and $500 \mathrm{kV}$ comprise only $2 \%$ of transmission lines [MoE / MWR, 1989]. The reported transmission loss in official statistics is $8.2 \%$, which is much lower than in other developing countries. But this result only includes lines connecting to 500 $\mathrm{kW}$ and higher transmission stations. Most likely, transmission losses in China are around $15 \%$, slightly worse than the best of the developing countries, like Brazil and South Korea at $12-13 \%$, and significantly better than the worst. For example, India and Pakistan suffer $20 \%$ losses because of extensive rural grids, which China does not yet have [Smil, 1986].

Despite the rapid growth in electricity generation and transmission, $40 \%$ of the rural population, or more than 300 million people, have no access to electricity.

\section{The future of electricity generation}

According to official projections, electricity generation will reach $1200 \mathrm{TWh}$ by the year 2000 [People's Daily, 1/25/89]. Of this, 225 TWh are projected to be hydrogeneration, 30 TWh nuclear, and the remaining 945 TWh thermal (this assumes 1988 average capacity factors of 0.42 for hydro and 0.67 for thermal generation nationwide) [ERI, 1988]. A total investment of about 240 billion yuan will be required. Table II.4 outlines the rough calculations used to arrive at this figure.

Construction necessary to meet the generation goals is determined to be the difference between present and projected capacity. When this is multiplied by the unit cost of new capacity, the total investment between 1988 and 2000 is estimated at 188 billion yuan (not including transmission), or about 15 billion yuan per year.

The investment necessary to achieve the prescribed growth is on a par with recent investments in the power industry, so it is reasonable to expect that capital constraints will not necessarily hinder the realization of this goal. However, that corresponding investments in other areas must be undertaken in order for this expansion to be supported and fully utilized cannot be emphasized too much. Coal mines and transportation and transmission infrastructure must be developed concomitantly. The transmission investment alone is on the order of 5 billion yuan per year.

Other constraints also limit the realization of this generation goal. Mine-mouth power plants will provide much of the $78.2 \mathrm{GW}$ projected increase in thermal generation. With more new power plants being constructed in the northern mining region, water shortages may become acute in some areas. Air cooling, a technology with which China has no experience, is likely to be required in some cases. 
Regional air quality could become a problem with more large power plants concentrated in a small area. Chinese coal is lower in heat value (average $21 \mathrm{MJ} / \mathrm{kg}$, compared to an average 26 $\mathrm{MJ} / \mathrm{kg}$ for American coals) and higher in ash than typical world coal. Emissions per unit generation are therefore higher for both reasons.

Big thermal power plants will be built to meet these energy projections. This expansion will be the main task of the power industry in the coming decade. Retrofitting and replacing old, inefficient small generation units is also important. As long as an electricity shortage exists, these inefficient units have to be kept running. Coal consumption with all its attendant impacts could be reduced by improving the efficiency of these units, which can be as low as $0.55 \mathrm{kgce} / \mathrm{kWh}$, compared to $0.37-0.40 \mathrm{kgce} / \mathrm{kWh}$ for new 200 and $300 \mathrm{MW}$ units designed in China [Wang, 1988].

Integration of the national transmission grid is also a development priority, requiring the construction of high-voltage long-distance transmission lines. Benefits would include reduced reserve requirements and increased load diversification, and such a system would allow the wider use of more efficient generation equipment.

\section{H. ENERGY IN VESTMENT}

Investment is perhaps the most important indicator of the priorities of Chinese energy policy and planning. Capital in China is scarce and meted out carefully. For any sector to capture an increasing share of investment clearly indicates its importance to Chinese energy planners. The energy industry has been the primary recipient of capital in China, accounting for about $15 \%$ of total investment and about one-third of investment in stateowned industry in the 1980s [SSB, 1988b, $1989 \mathrm{a} \& \mathrm{~b}$ ]. Energy investment, especially in the power sector, has also been on the rise. Total investment in the energy sector surpassed 60 billion yuan per year in 1988, as illustrated in Figure II.11.

Until 1984, energy investment had been split almost evenly among the three major subsectors (coal, petroleum, and power). At this point, in response to a worsening electricity shortage that caused slack industrial capacity, investment in the power industry increased sharply (from $45 \%$ to $60 \%$ ). This increase has been partially at the expense of other sectors. Investment in the oil and gas industry has also gained steadily since the mid-1980s, but at a slower rate, so their shares of the total have decreased.

Investment in the coal industry, the backbone of China's energy supply, has not increased much since 1984. Coal shortages began in 1988 and have caused many power plants in the nation's industrial areas to operate at less than full capacity.

Although the government has been increasing its investment in the petroleum sector, the yield has been disappointing. The ratio of new production to investment has dropped $40 \%$ since 1984. An increasing portion of available investment funds must be used to maintain production at the expense of exploration. Investment in natural gas (primarily for prospecting) actually decreased from 1985 to

\begin{tabular}{lcccccc} 
Table II.4: & $\begin{array}{c}\text { Investment in Electrical } \\
\text { Capacity } \\
\text { Required } \\
\text { (GW) }\end{array}$ & $\begin{array}{c}\mathbf{1 9 8 8} \\
\text { Installed } \\
\text { (GW) }\end{array}$ & $\begin{array}{c}\text { Sector to Meet Demand Projections. } \\
\text { Construction } \\
\text { Necessary } \\
\text { (GW) }\end{array}$ & $\begin{array}{c}\text { Unit Cost } \\
\text { (yuan/kW) }\end{array}$ & $\begin{array}{c}\text { Necessary } \\
\text { Investment } \\
\text { (B yuan) }\end{array}$ & $\begin{array}{c}\text { Per Year } \\
\text { (B yuan) }\end{array}$ \\
\hline Fossil & 161 & 82.8 & 78.2 & 1270 & 99 & 8.3 \\
Hydro & 61 & 32.7 & 28.3 & 2250 & 64 & 5.3 \\
Nuclear & 5 & 0 & 5 & -5000 & 25 & 2.1 \\
Transmission & & & 111.5 & -500 & 56 & 4.6 \\
Total & & & & & & 20.3
\end{tabular}

Source: Xia Meixiu, 1989, for unit costs of construction. (We assume these figures to be in 1988 yuan.) 
Figure II.11: Investment in Energy, 1981-1988.

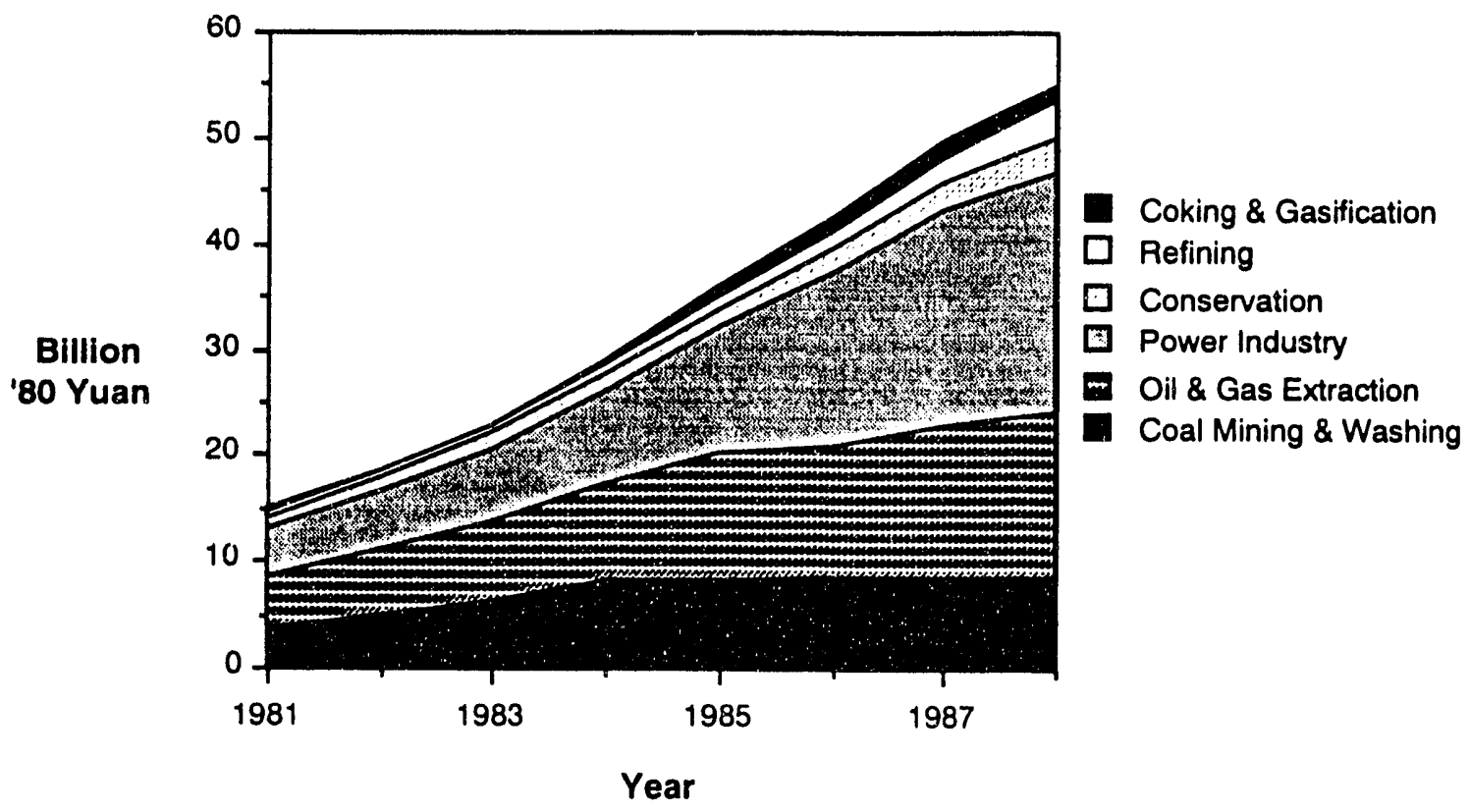

Note: Private investment is not included in this figure. Conservation investment for $1981-1989$ is estimrated assuming that government investment is $70 \%$ of the 10 billion yuan reported for this period.

\section{Source: Energy Statistical Yearbook of China, 1989.}

1988 (from 498 million yuan to 162 million yuan), because maintaining production growth of coal and petroleum are more inmediate investment priorities, and new gas discoveries have not met expectations.

In the coal industry, investment provided by rural collective or private mines has not been accounted for. That these mines have provided most of the increase in production figures in recent years may explain the small increase in coal investment. However, rural mines are generally very small and poorly equipped. Unit investment is much lower than in large mines. Investment in large coal projects is therefore also important and has perhaps been neglected in recent years.

Investment in coal washing has always been overlooked. Maintaining production increases takes precedence. To ensure a stable future supply, rural mines must be upgraded, stateowned large mines need to become more productive, new mines have to be constructed, new washing facilities have to be provided, and a larger transportation capacity has to be put in place. All these indicate the pressing need for investment in the coal industry.

The Chinese government also realized the importance of investing in energy conservation. Special loan incentives were established in the early 1980s. From 1981 to 1985 , total investment in energy contservation from central and local governments amounted to 10 billion yuan. Many of these investments have been very costeffective and are, in total, estimated to reduce China's energy demand by 25 Mtce [Levine and Xueyi, 1990]. Investment in energy conservation has increased gradually since 1985 , reaching 3052 million yuan in 1988 [SSB, 1989a]. Although conservation investment is small in comparison to suppiy investment, its impact on China's economy is significant. We estimate that by investment in energy conservation, China was able to cut its growth rate of energy consumption by about 3\% since 1985. Properly targeted investments in conservation can reduce demand more than the same investments on the supply side can increase production. China is studying how to target these conservation investments, and the results appear promising. 


\section{RURAL ENERGY SUPPLY}

Rural China depends on local resources for energy supply. Most available are crop stalks, firewood, and locally produced coal. In 1987, total crop stalk production was estimated at 560 Mtons (268 Mtce at a conversion factor of 0.48 tce/ton) and the total sustainable yield of firewood was 136 Mtons ( 77 Mtce at a conversion factor of 0.57 tce/ton). Actual consumption of crop stalks and firewood was 130 Mtce and 133 Mtce respectively [SPC 1990]. The supply of coal and electricity is limited to those rural residents who have easiest access. In most of China's rural areas fuel and electricity are in chronic shortage.

The rural energy shortage and its consequences have received more government attention recently. There have been four major campaigns addressing this issue during the last 15 years: small hydropower projects, household biogas digesters, efficient cookstoves, and firewood tree planting.

Construction of small hydro projects (with a site capacity $12 \mathrm{MW}$ or less) became very widespread during the 1970s, with total installed capacity increasing from $900 \mathrm{MW}$ in 1970 to $6330 \mathrm{MW}$ in 1979 [Wang, 1988]. During the 1980s, development remained rapid. By the end of 1988, total installed capacity reached $11,800 \mathrm{MW}$, generating 31 billion $\mathrm{kWh}$ of electricity in 1988, or about half of rural electricity consumption [MoE, 1989]. China has about $70 \mathrm{GW}$ of exploitable small hydro resources which are mainly found in the south and southwest, which also happens to be the most populous rural area. Present installed capacity is about $17 \%$ of the total exploitable capacity [MoE, 1989]. Small hydropower stations have become a major force in rural electrification.

The utilization rate is low for these stations. Generation has been only about $40 \%$ of total installed capacity [Wang, 1988]. Unstable water sources and mismanagement both contribute to this outcome. Rationally utilizing and developing this regional energy resource is very important to improve the rural standard of living.
Another major rural energy campaign that started in the early 1970 s was popularizing household biogas digesters. This mass movement also unfolded mostly in southern provinces, where firewood is in shortest supply and local coal reserves are scarce. From 1973 to 1978, the number of digesters jumped from nothing to 7.14 million. Sichuan province alone had about 5 million digesters. Unfortunately, this rapid increase was purchased in part by poor quality. As malfunctioning digesters were decommissioned, their numbers decreased sharply after 1979, to about 4 million in 1983. Development then became more qualityoriented. By the end of 1987, the number of digesters had reached about 4.5 million nationally.

Most digesters are cost effective. The investment in a new digester is generally less than the cost of producing one ton of coal locally. A sample study in Sichuan province showed that a well managed digester could produce $227-426$ cubic meters of biogas per year and save about one ton of coal per year [He, 1988].

From 1975 to 1987 , total biogas production was about 800 million cubic meters, which is equal to about 1.5 Mtce. Although this number is small compared with the present consumption of 270 Mtce biomass yearly, its future role in rural household energy supply should not be understated. To keep this technology attractive, new digesters that are affordable and operationally convenient have to be developed [He, 1988].

The health effects of inhaling woodsmoke from cookfires is a serious problem in rural areas of LDCs. Biogas burns cleanly and resolves this problem. Furthermore, biogas has the additional benefit of producing a high-quality fertilizer as a byproduct. The importance of developing rural biogas needs emphasis.

By the end of the 1970s the rural biogas program was under scrutiny and sharp criticism. The government launched another project in 1980 to help alleviate the rural cooking fuel shortage. The goals of this program were to both improve the efficiency of rural cooking stoves, and simultaneously encourage the planting of firewood trees. From 1982 to 1987, 
about $45 \%$ of rural households installed energysaving stoves. The conversion efficiency of these stoves ranged from $20 \%$ to $30 \%$, compared with $10 \%$ or less for the older stoves. The yearly energy savings generated by this program was about 20 Mtce [Liang, 1988]. This is an impressive number, and lessens the burden on already stressed rural ecosystems for providing biomass fuel.

Another active project coordinated with efficient stoves is the planting of firewood trees. By the end of 1987, this program had planted 5.7 million hectares [MoE, 1989]. The goal of this program is to provide firewood as the major household fuel in rural areas by the year 2000 .

Both small hydro projects and biogas digesters can be implemented only in the south and southwest, where the weather is humid and warm, and where hydro resources are rich. The efficient stoves and firewood treeplanting project is effective nationwide.

The Chinese government has formed a special department for ruisl energy issues under the newly formed Ministry of Energy. A series of regional energy plans that take local natural resources and economic situations into account have been developed. To thoroughly solve rural energy problems might be too high an expectation for a country that already suffers from serious energy shortages, but with the successful implementation of practical rural energy policies, China's rural areas will have a brighter energy future.

\section{J. CONCLUSIONS}

After 40 years of rapid development, China's energy industries are facing an unprecedented challenge to meet future demand. Imperfect coordination between energy supply and other economic sectors has resulted in energy shortages. The domestic-based, long-term energy strategy has been proven effective in increasing production, but may face some serious challenges when oil and natural gas can no longer meet increasing demand, and if the environmental burden of coal burning becomes unacceptable.

Future gas production is still subject to a large degree of uncertainty. Identifying any large reserves would ease the pressure on other fuels. Investments in prospecting could yield important payoffs. But despite this, China has more recently chosen to invest in meeting more immediate production requirements. Balancing this tension between short-term and longerterm energy production will require careful planning and merits more study.

Capital is also necessary for both increasing production and improving infrastructure. These projects should be adequately productive to attract international investment, if political considerations allow it.

Coal and hydropower, and therefore electricity, will be the cornerstones of China's future energy supply. Careful attention should be given to proper development and utilization of China's immense coal resources. Protection of the environment from the harmful effects of coal utilization will be a necessary aspect of these policies.

Finally, there still exists a large potential to improve the efficiency of the delivery of energy services. Conservation investments simultaneously mitigate the previously mentioned environmental impacts and can often be much more cost-effective than the construction of new supply. Chinese ministries need to adapt to provide integrated planning that simultaneously addresses these issues. 


\section{References}

Department of Energy / Energy Information Agency, Annual Review of Energy, 1989.

Energy Research Institute (ERI), Perspectives on Electricity Development, (Beijing: 1988).

He Liang, Critical Review on the Development of Rural Household Biogas Digesters, Energy Journal, Beijing, No.4, 1988.

Hung Yicheng, "About the Medium Term Development Strategy of China's Energy Industry," Energy Journal, No. 1 1989, Beijing.

Levine, Mark and Liu Xueyi, Energy Conservation Programs in the People's Republic of China, (Draft LBL report, 1990).

Liang Baofen, et al, "Effirient Stove and Energy Conservation," Proceedings: Energy Future and New Conservation Technologies, (Beijing, 1988).

Ma, Xuechang, "On Exploration and Exploitation of China's Energy Resources," Proceedings: Energy Future and Conservation Technology (Beijing: 1988).

Ministry of Energy (MoE), Energy in China, (Beijing, 1989, 1930).

Ministry of Energy and the Ministry of Water Resources (MWR), Information Research Institute of Water Resources and Electric Power, China's Construction in Four Decades, Vol. X: Electric Power (Hong Kong, 1989).

People's Daily (Overseas Edition), 1/25/89, $10 / 16,90$.

Schipper, L. and R. C. Cooper, Energy Use and Eonservation in the USSR, LBL-29830, 1991.

Smil, Vaclav, Energy in China's Modernization, (New York: M. E. Sharpe, Inc., 1988).
State Statistical Bureau of China, Energy Statistical Yearbook of China, (Beijing: 1989).

State Statistical Bureau of China, Statistical Yearbook of China, (Beijing: 1988, 1989, 1990, 1991).

State Statistical Bureau of China, Yearbook of China's Transportation, (Beijing: 1987).

State Statistical Bureau of China, Yearbook of China's Coal Industry. (Beijing: 1987).

State Statistical Bureau of China, Yearbook of China's Economy, (Beijing: 1988).

US Department of Energy, Coal Production 1986, DOE/EIA-0118(86), (Washington DC: US Government Printing Office, 1986).

US Department of Energy, The Petroleum Resources of China, DOE/EIA-0501, (Washington DC: 1987).

Wang Qingyi, Energy in China, (Metallurgical Industry Publish House: 1988).

Weil, M., "The Rise and Fall of Antaibao," The China Business Review, Vol. 18, No. 2, 1991.

Xia Meixiou, "Electricity Pricing and its Crisis," Energy of China, No. 1, (Beijing: 1989).

Xie Guoshi, "China's Coal Market: Growth of Demand Exceeds Development of Production," Economic Information Agency, China Market, No .10, (Hong Kong, 1988).

Yang Yuexian, "Firewood Consumption and Forest Energy Development in China," Proceedings of the Third National Rural Energy Conference (Beijing: Academic Journal Press, 1988).

State Planning Commission, Department of Resources Conservation and Comprehensive Utilization, National Rural Energy Planning, (original in Chinese) (Beijing: Standards Press, 1990). 
PART III

ENERGY DEMAND

\section{A. ENERGY CONSUMPTION OVERVIEW}

In 1988 China consumed 930 Mtce of commercial energy representing about $9 \%$ of world consumption, compared to China's $21 \%$ share of the world's population. Figure III.1 provides an international comparison of total energy consumption, which shows that by 1988 China was consuming more coal than any other nation.

Figure III. 2 compares energy corisumption in these countries on a per capita basis. The disparity between the developing and developed countries is magnified because of the huge populations of China (and india). Only modern (commercial) fuels are counted in this chart.

Total per capita commercial energy end-use was 0.8 tce in China in 1988, compared with less than 0.5 tce in India, and 7.1 and 11.8 tce in the USSR and the US respectively. Population growth rates in 1988 were $1.7 \%$ in China and $1.9 \%, 1.0 \%$, and $1.0 \%$ for India the USSR, and the US respectively. Because population is growing faster in developing countries, energy consumption must do the same to maintain per capita consumption.

Commercial primary energy consumption has indeed grown steadily and rapidly since the PRC was founded, at an average annual rate of $8.3 \%$ between 1952 and 1990 (from 47 Mtce to $980 \mathrm{Mtce}$ ). Because international trade and stockpiling have remained small, commercial energy consumption in China has followed production closely, so Figure III.3 looks very similar to Figure 3 in Part II.

China's heavy reliance on coal is again evident in this figure. Starting from $95 \%$ in 1952, the coal share of commercial energy consumption decreased slowly. Currently the dominance of coal is again on the rise, having bottomed out at $70 \%$ in 1976 with peaking oil production. Coal currently (1990) supplies $76 \%$ of commercial end-use. The shortage of other fuels (and electricity) has proven to be a significant obstacle to the development of China's national economy. Total commercial energy consumption by sector is depicted in Figure III.4. Some adjustments to the raw data in this figure were made in order to allow more meaningful international comparisons. These adjustments are (1) the construction sector is lumped into the industrial sector; (2) self-use by electric utilities is subtracted from industrial energy use; (3) non-fuel petroleum and coking products are taken out from the industrial total energy use reported by the yearbook (the adjusted industrial energy use still includes some feedstocks consumption, ranging between $7 \%$ and $9 \%$ of the adjusted total industrial energy use between 1980 and 1985; we were not able to fully adjust the industrial energy use for feedstocks because the data were lacking for years after 1985); (4) all gasoline use is assumed to be transportatior، cuel use; and (5) $20 \%$ of agricultural diesel use and $10 \%$ of industrial diesel use are assumed to be transportation fuel use (see the section on the transportation sector for a rationale for these shares).

From these figures, two characteristics of energy consumption in China that merit closer examination are evident: (1) the predominance of coal as a fuel, and (2) the high share of industry in energy consumption. Two other key features of the energy situation should also be emphasized. First, China relies heavily on (noncommercial) biomass consumption for energy services, especially in rural areas for residential needs. Second, significant inefficiency is observed in all sectors, so large gains from conservation are possible. All four of these issues will be discussed in detail in the following sections. 
Figure III.1: Primary Energy Consumption by Fuel, Selected Countries, 1988.

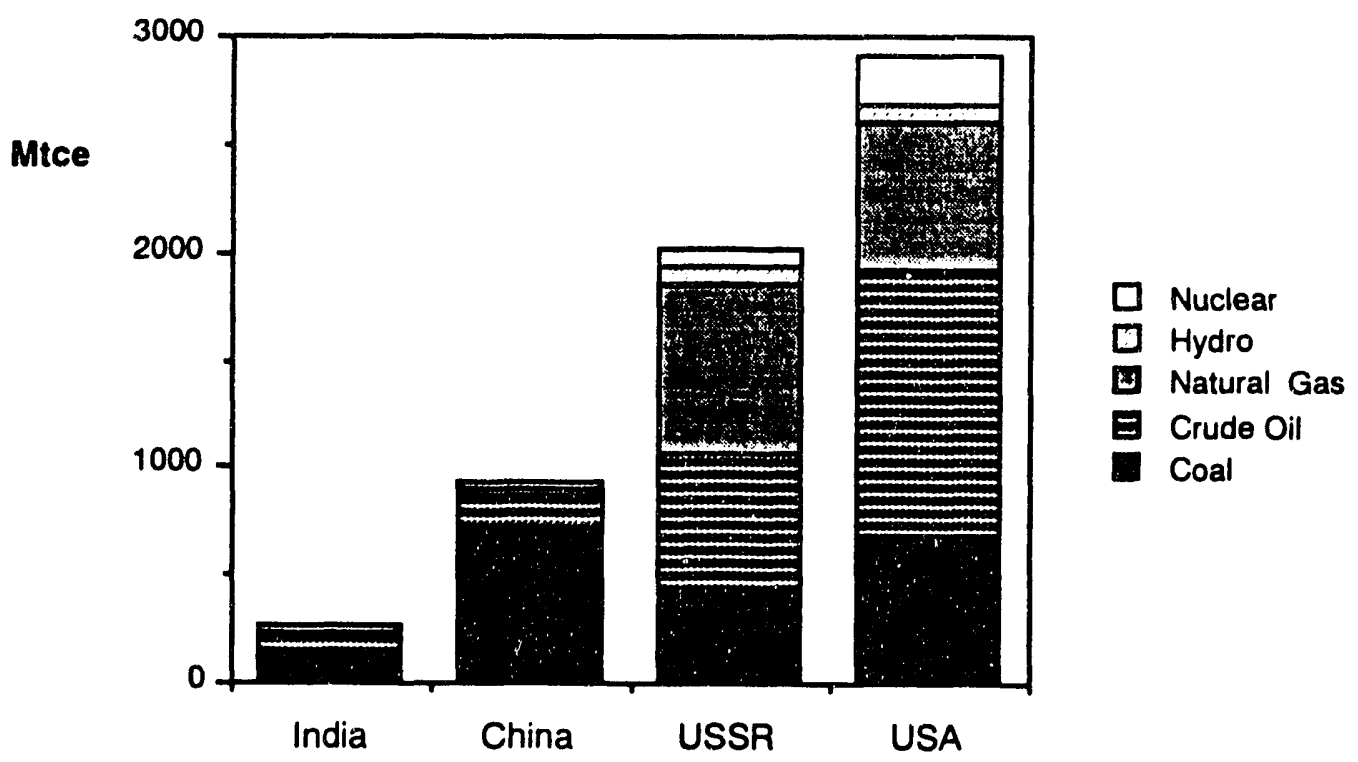

Sources: China - Energy Statistical Yearbook of China, 1989; India - International Energy Studies Database, Lawrence Berkeley Laboratory, 1991; USSR - BP Review of World Energy, 1990; USA - Annual Energy Review, 1990.

Figure III.2: Per Capita Primary Energy Consumption, Selected Countries, 1988.

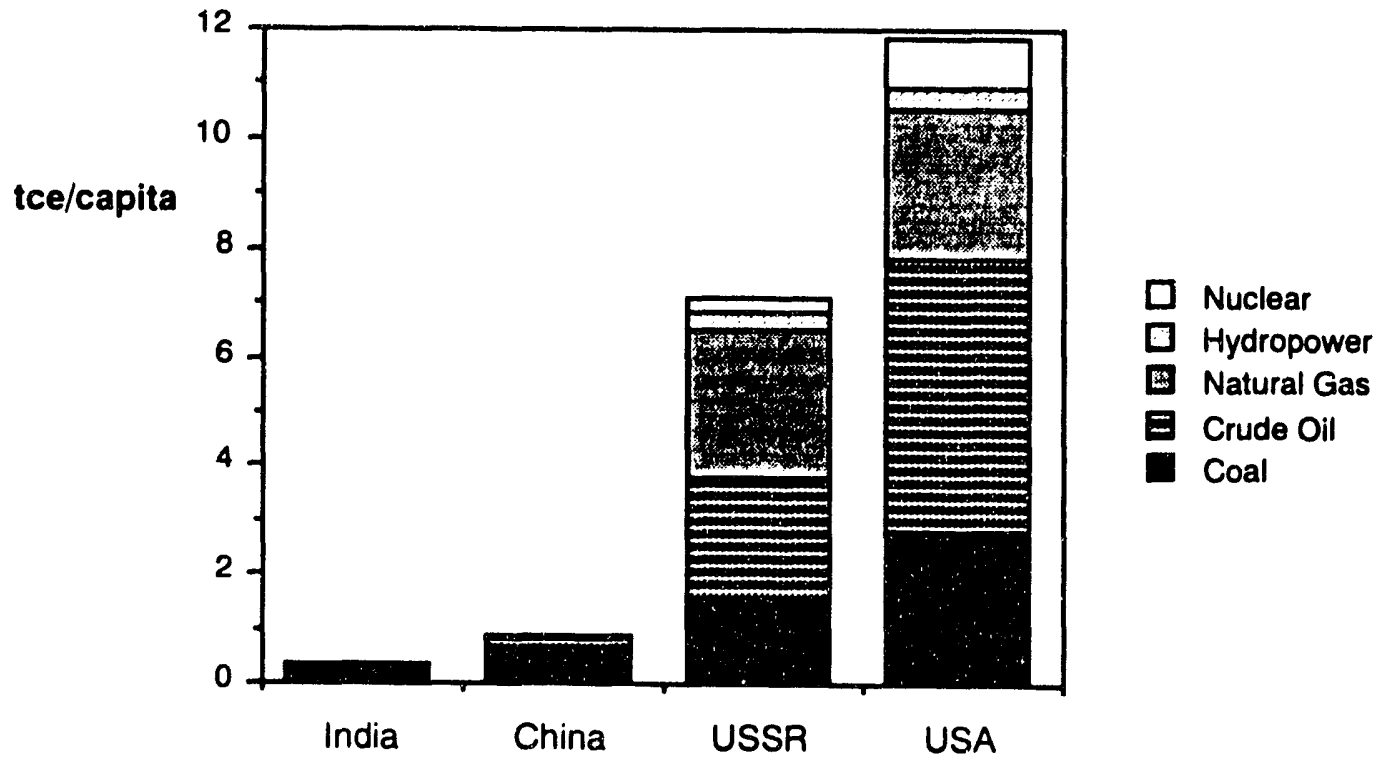

Sources: same as above for energy data. Population data are from the Statistical Abstract for the US, and the International Energy Studies database (projected one year for the USSR). 
Figure III.3: Total Primary Energy Consumption by Source, 1952-1988.

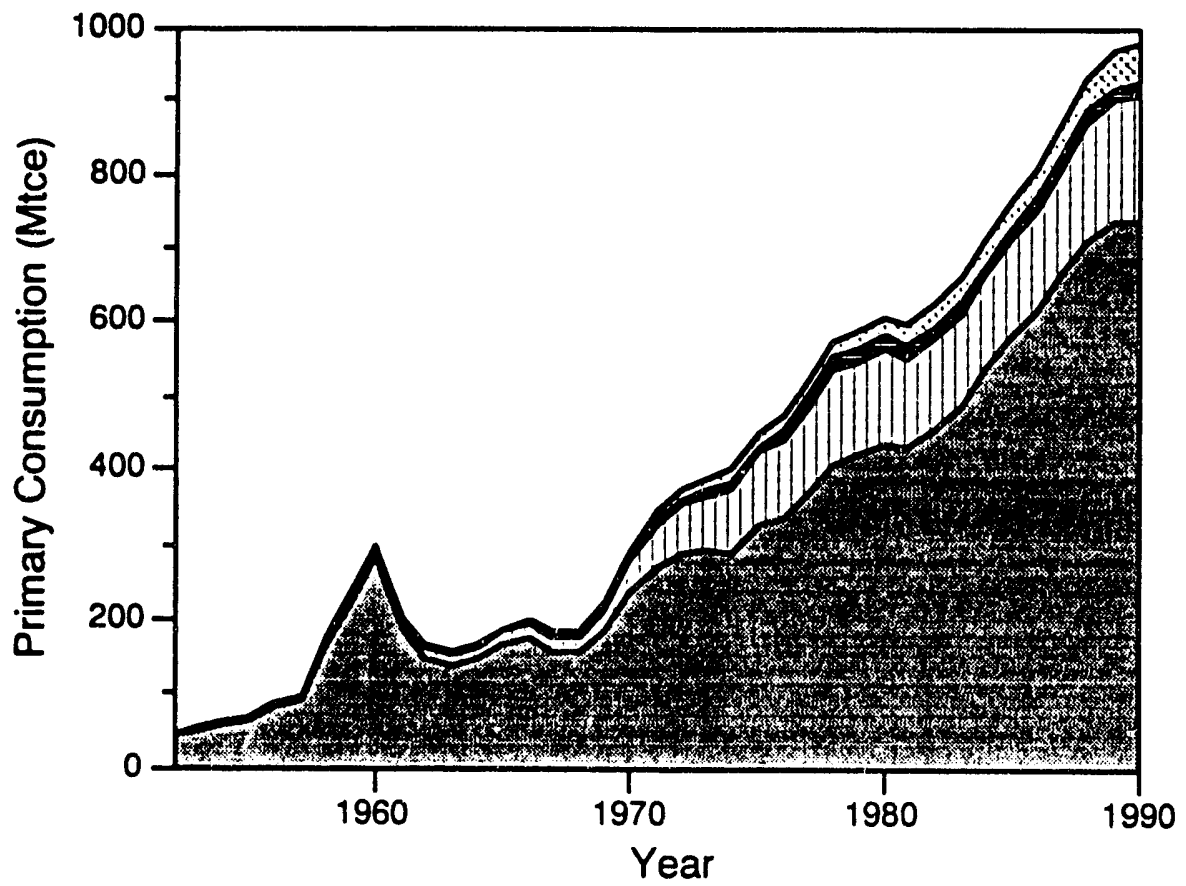

Hydroelectricity

Natural Gas

ㅁiा Petroleum

Coal

Source: Energy Statistical Yearbook of China, 1989; China Statistical Yearbook, 1991; Energy in China, 1990.

Figure III.4: Commercial End-Use Energy Consumption by Sector, 1980-1988.

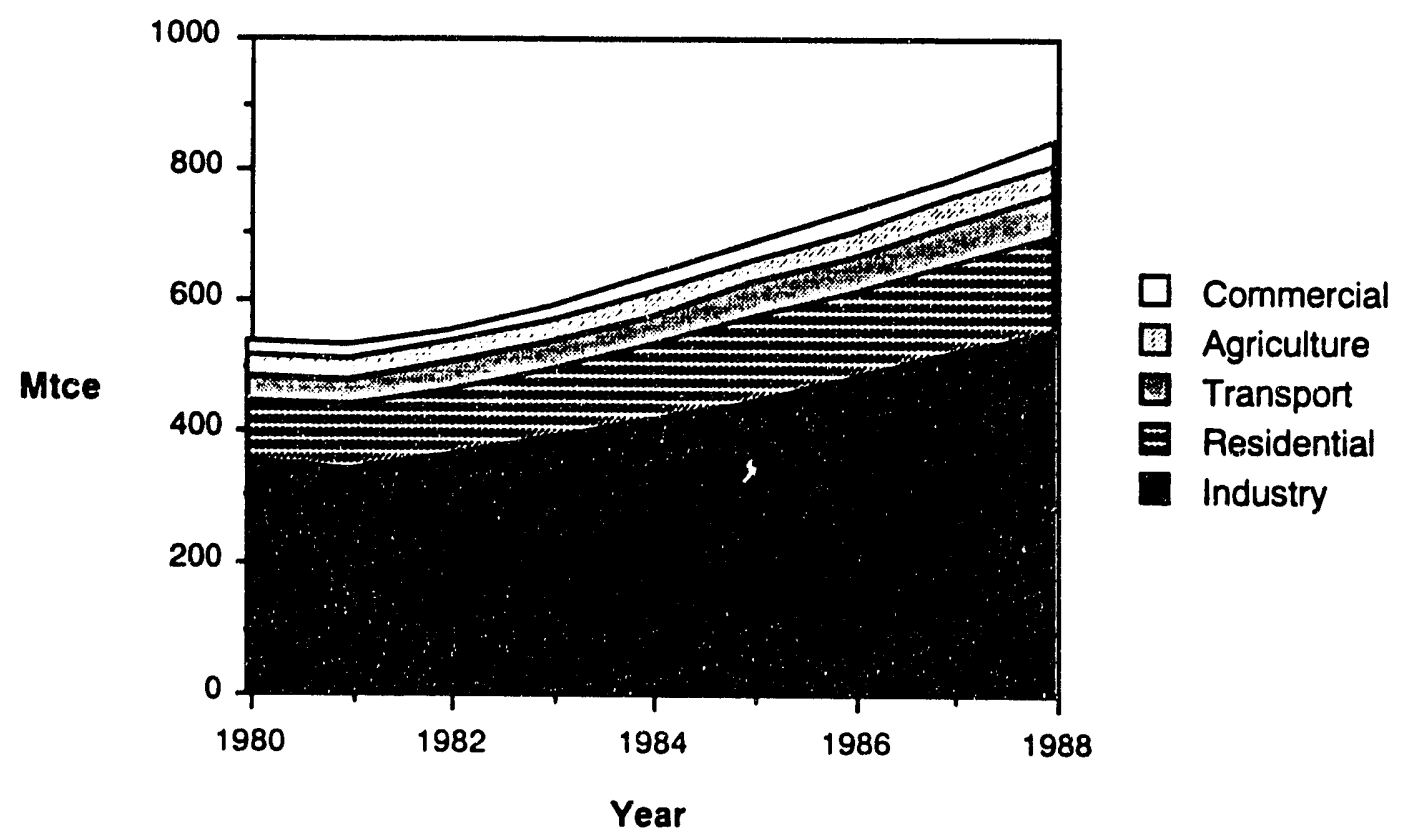

Source: Energy Statistical Yearbook of China, 1989. 


\section{Coal: the dominant fuel}

China is the world's leading coal consumer, with current raw coal consumption in excess of one billion tons annually, almost $30 \%$ of the world total. With official projections of 1400 million tons annual consumption by the year 2000, China is expected to maintain this lead [UN REDP, 1989]. However, because the average coal consumed in China is low quality, with a low heat content (20.9 $\mathrm{MJ} /$ ton unwashed, compared to standard coal with $29.3 \mathrm{MJ} / \mathrm{ton}$ ), the US still consumed about as much in heat equivalents in 1988. Figure III.5 illustrates this, as well as China's increasing share of world coal consumption.

Not only does China consume more coal than any other nation, it also depends more heavily on coal relative to other fuels. This is illustrated in Figure III.6.

This dependence on coal has several undesirable results. Chinese coal as currently produced has a low average heat content and is often burned unwashed, unsorted, and unscrubbed in small, inefficient boilers with few enissions controls. These difficulties plague the residential sector and much of the industrial sector in China. Furthermore, these sectors are large compared to those of other countries. Sectoral coal consumption for the four comparison nations is given in Figure III.7. Although China and the US consume about the same amount of coal, coal-caused air pollution problems are much more serious in China because of dispersed utilization.

Acid rain and poor urban air quality resulting from widespread decentralized, inefficient coal combustion are serious problems in China. Because coal generates the most carbon dioxide per unit heat of any fuel, China is also a large and growing contributor to global atmospheric $\mathrm{CO}_{2}$.

\section{Industry: the main consumer}

In 1988 industry accounted for $65 \%$ of all final commercial energy use in China [Energy Statistical Yearbook of China, 1989]. Moreover, the industrial sector uses
$75 \%$ of all delivered electricity. These shares are higher than industrialized nations, except the USSR, on whose development strategies the Chinese have based many of their own. This emphasis is illustrated in Figure III.8. As can be seen from this figure, the residential/commercial sector also accounts for a significant share of energy consumption in China.

\section{Traditional fuels}

China consumes far more biofuels than any other country in the world. Crop stalks are gathered as carefully as the crops themselves, and fuelwood forests are planted extensively. The result is that about half a billion tons of biomass fuels are consumed annually in China. Figure III.9 shows how this compares with the nations that have the next highest total biomass consumption.

The sectoral shares of energy end-use in China are sensitive to the inclusion of biomass. When biomass energy consumption is included, industry's share decreases to a moderate $50 \%$. The residential/commercial sector takes up the difference, its share of energy use jumping to $40 \%$. Figure III.10 illustrates the effects of including biomass in the international comparison of energy use.

Biomass is consumed primarily in rural residences. In 1987, biomass consumption consisting of 230 Mtons of firewood and 270 Mtons of crop residue totaled 270 Mtce [National Rural Energy Planning, 1990]. ${ }^{1}$ Including biomass (and assuming biomass consumption grew at the same rate as population), China's total primary energy consumption in 1988 was about 1200 Mtce, or about 1 tce per capita. The composition of primary energy consumption in 1988 by source was coal $59.2 \%$, biomass $22.2 \%$, oil $13.3 \%$, natural gas $1.6 \%$, and hydroelectricity $3.8 \%$. Biomass is consumed almost exclusively for heating and cooking services in the rural residential sector.

1 Assuming 0.57 and 0.48 tce/ton for firewood and crop residue respectively. 
Patterns of biomass consumption have an impact on the rural environment in several ways. Diverting crop residues from returning to the soil can reduce soil fertility and increase the need for fossil fertilizer inputs. It is estimated that about $50 \%$ of crop wastes are currently used as fuel. The current rate of harvesting trees for fuel use is not sustainable. Annual firewood deficit is estimated at about 100 million ton [National Rural Energy Planning, 1990]. Net deforestation is occurring at a rate of about $1.5 \%$ of China's total forest cover per year
[Smil, 1988]. Deforestation, soil loss, and desertification are pressing problems in China.

Because biomass is noncommercial energy, its accounting is neither comprehensive nor accurate. The unreliability of biomass data relative to those data for commercial energy, biomass forces us to treat this area less comprehensively than the Chinese reliance on it as an energy source demands. However, additional attention is given to biofuels in the section on residential end use.

\section{Figure III.5: World Coal Consumption, Selected Countries}

1970.

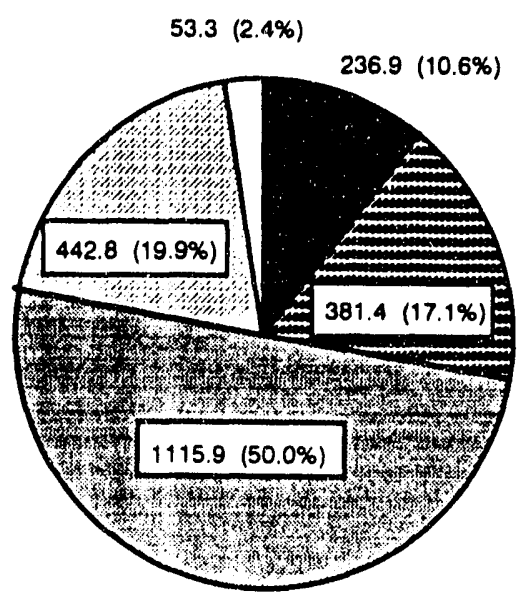

1988.

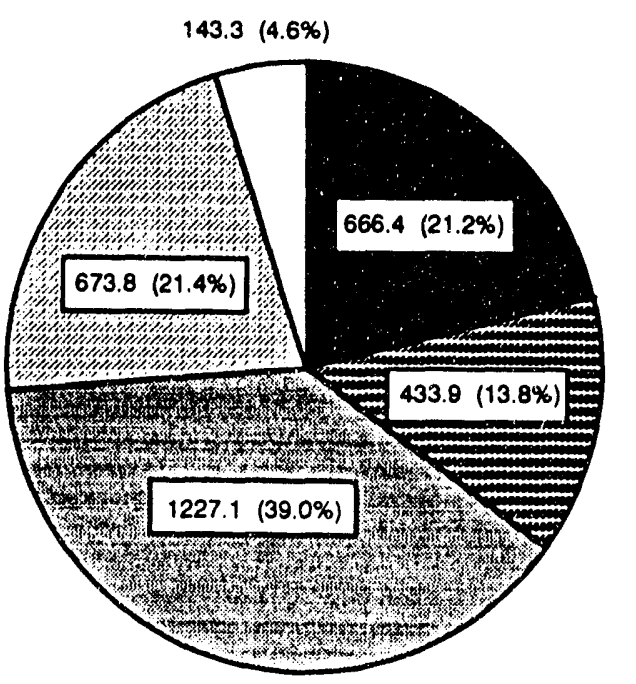

- China

- USSR

India

U USA

ROW

(Mtce)

Sources: 1970 / China - Statistical Yearbook of China, 1988; USSR \& India - International Energy Studies database, Energy Analysis Program, Lawrence Berkeley Laboratory, Berkeley, 1991; USA - Energy Information Agency, 1990; ROW - British Petroleum, 1990; 1988 / BP Statistical Review of World Energy, 1990, except for India - International Energy Studies database, 1991.

Note: ROW - Rest Of World. 
Figure III.6: Selected Source Shares of End-Use Energy Consumption, 1987.

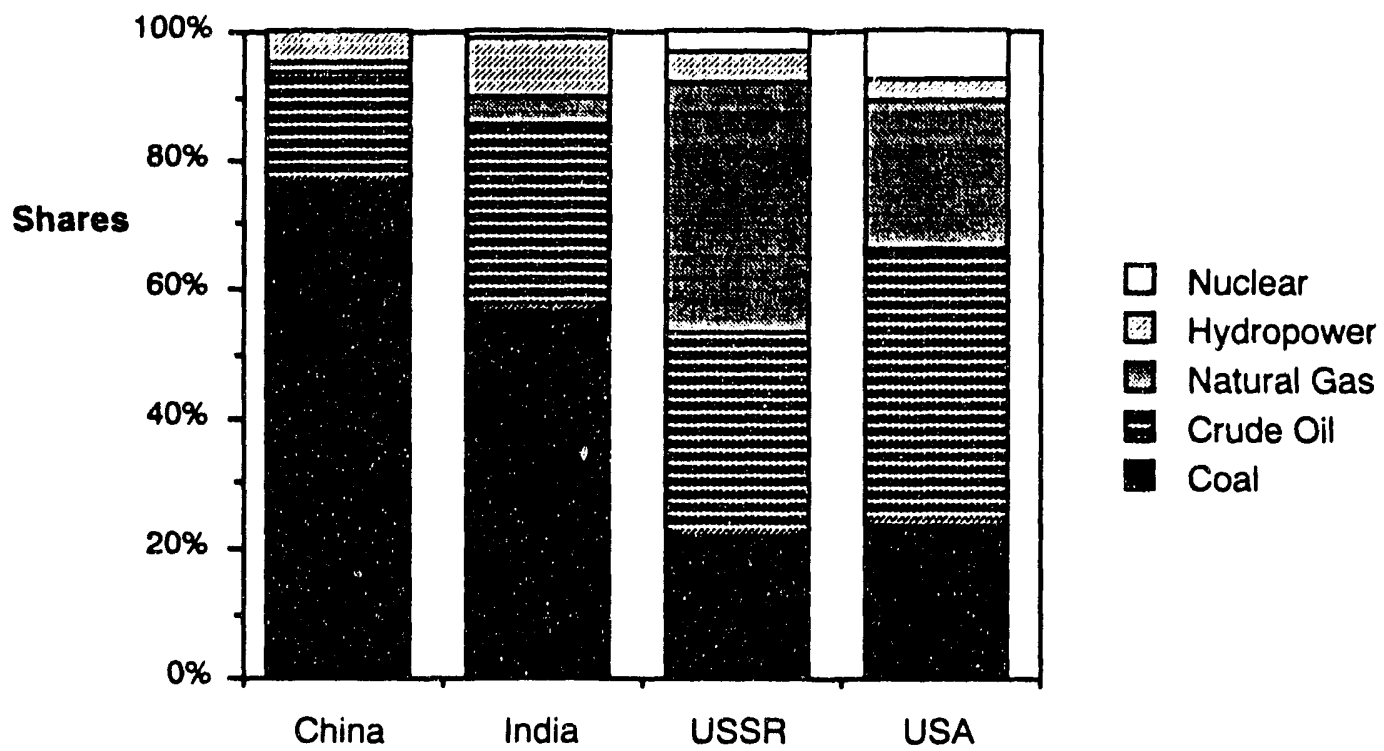

Sources: China - Energy Statistics Yearbook of China, 1989; India - International Energy Studies database, Energy Analysis Program, Lawrence Berkeley Laboratory, Berkeley, 1990; USSR - World Energy Statistics and Balances, 1971-1987; USA - Annual Energy Review, 1989.

Notes: District heat data for India and the US are not available, but are expected to be very small. The conversion factor for electricity is $0.404 \mathrm{kgce} / \mathrm{kWh}$.

Figure III.7: Coal Consumption, Selected Countries, 1987.

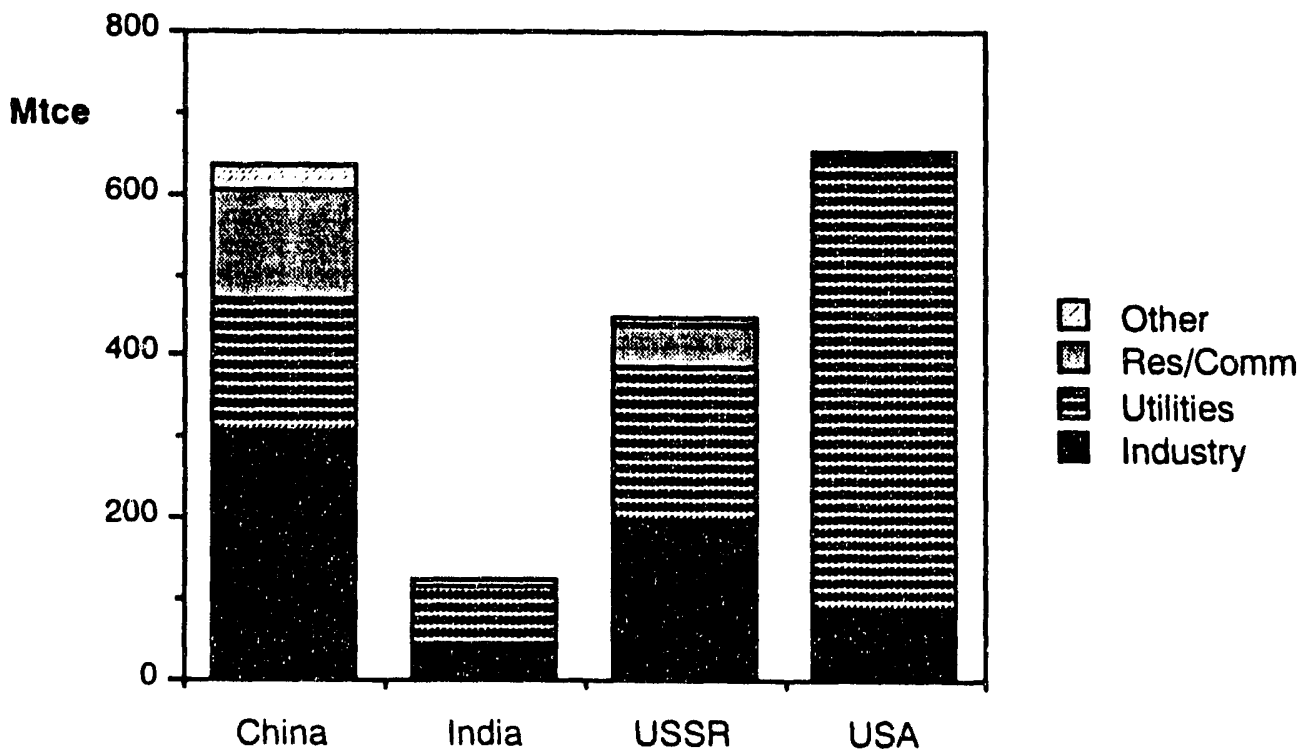

Sources: China - Energy Statistics Yearbook of China, 1989; India - International Energy Studies database, Energy Analysis Program, Lawrence Berkeley Laboratory, Berkeley, 1990; USSR - World Energy Statistics and Balances, 1971-1987; USA - Annual Energy Review, 1989. 
Figure III.8: Sectoral Shares of Commercial Energy End-Use, 1987.

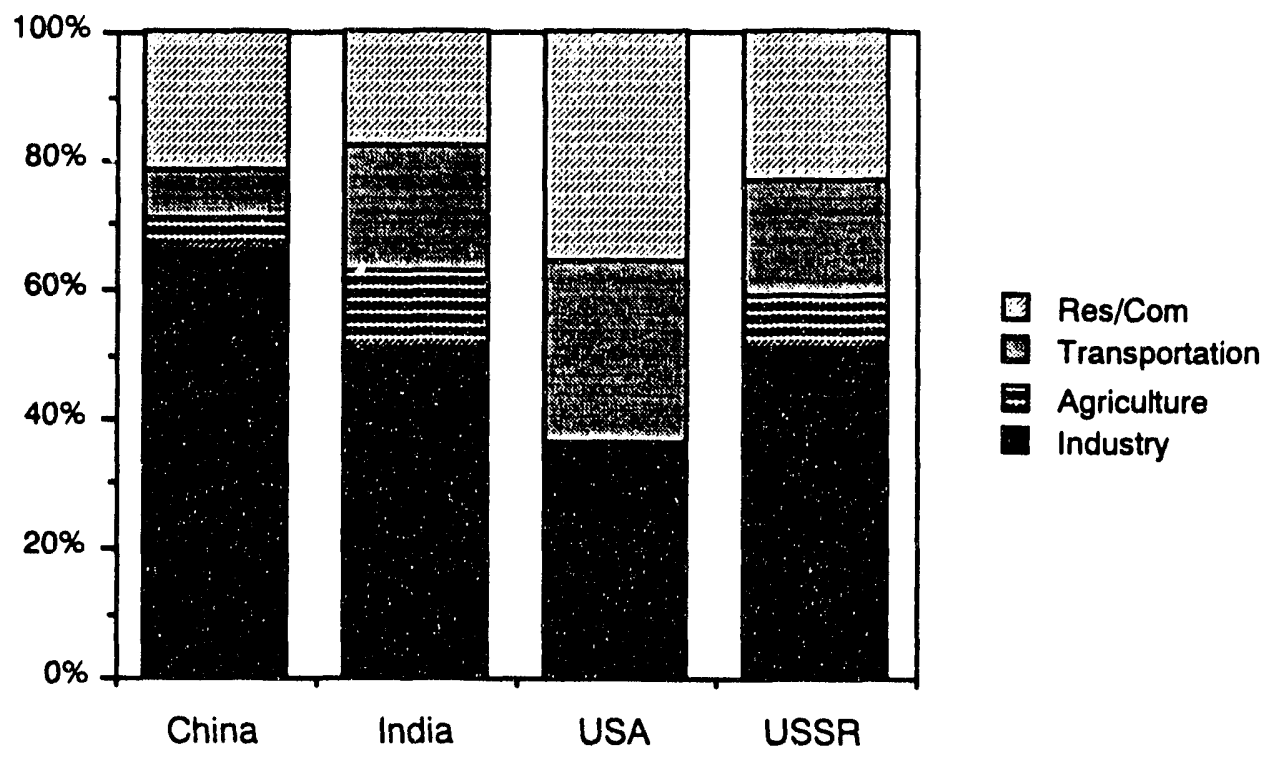

Sources: China - Energy Statistics Yearbook of China, 1989; India - International Energy Studies database, Energy Analysis Prograrn, Lawrence Berkeley Laboratory, 1990; USSR - Energy Use and Conservation in the USSR, Schipper \& Cooper; USA - IEA, Energy Balances of OECD Countries, 1987-1988, 1990.

Figure III.9: Biomass Consumption, Selected Countries, 1988.

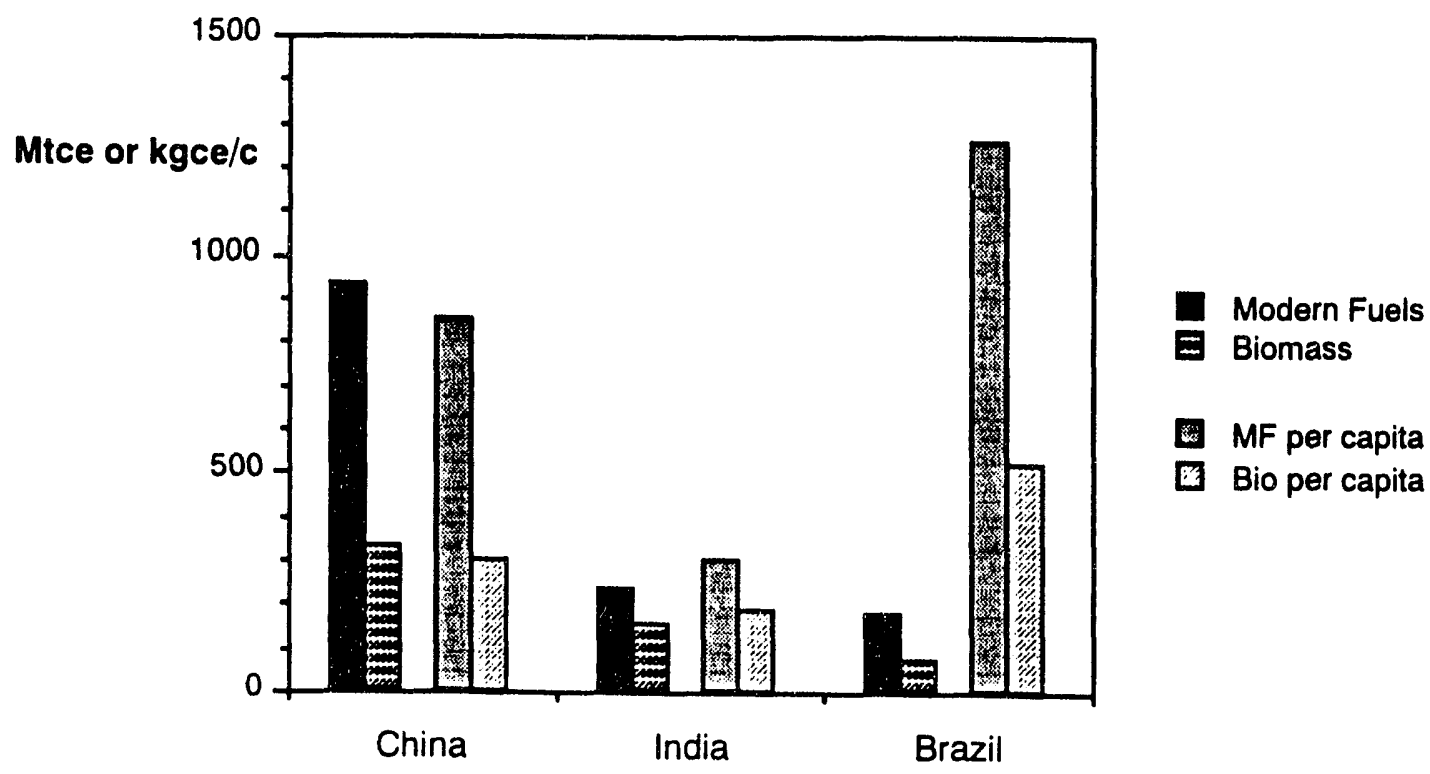

Column 4

Sources: China - Energy in China (Ministry of Energy, 1989), 1989; India and Brazil - International Energy Studies Database, Energy Analysis Program, Lawrence Berkeley Laboratory, 1990. 
Figure III.10: Energy End-Use by Fuel, Selected Countries, 1987.

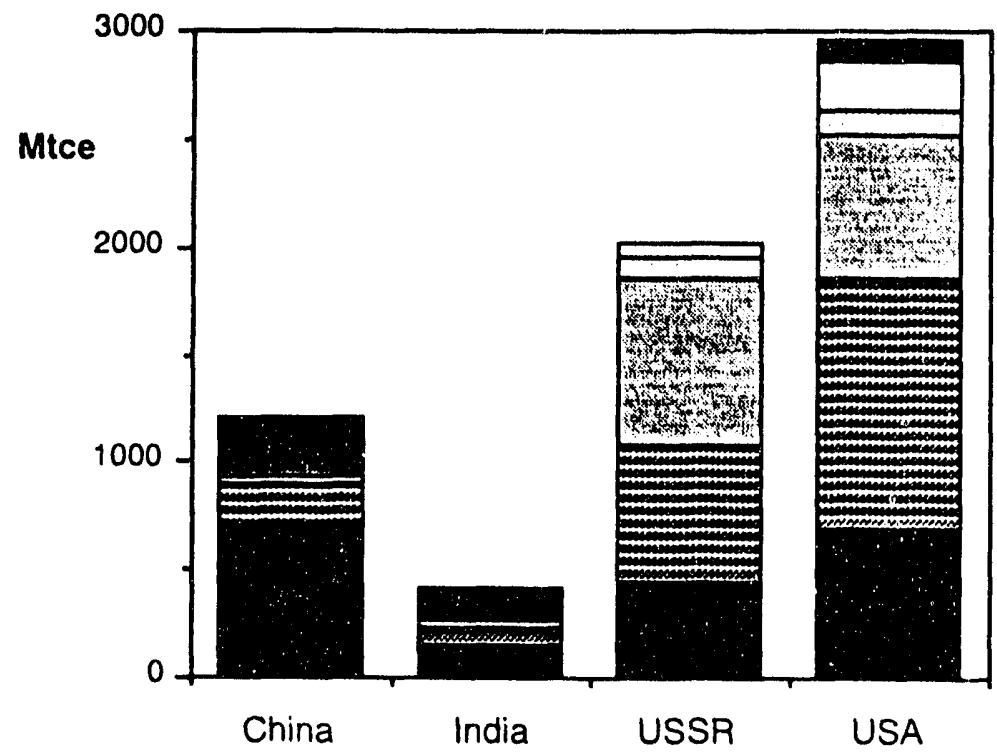
... Biomass
$\square$ Nuclear
$\square$ Hydropower
$\square$ Natural Gas
Crude Oil
Coal

Sources: China - Energy Statistical Yearbook of China, 1989; India - International Energy Studies Database, Lawrence Berkeley Laboratory, 1991; USSR - Energy Use and Conservation in the USSR, Schipper \& Cooper; USA -- Annual Energy Review, 1990.

Figure III.11: National Income, 1952-1989, By Sector.

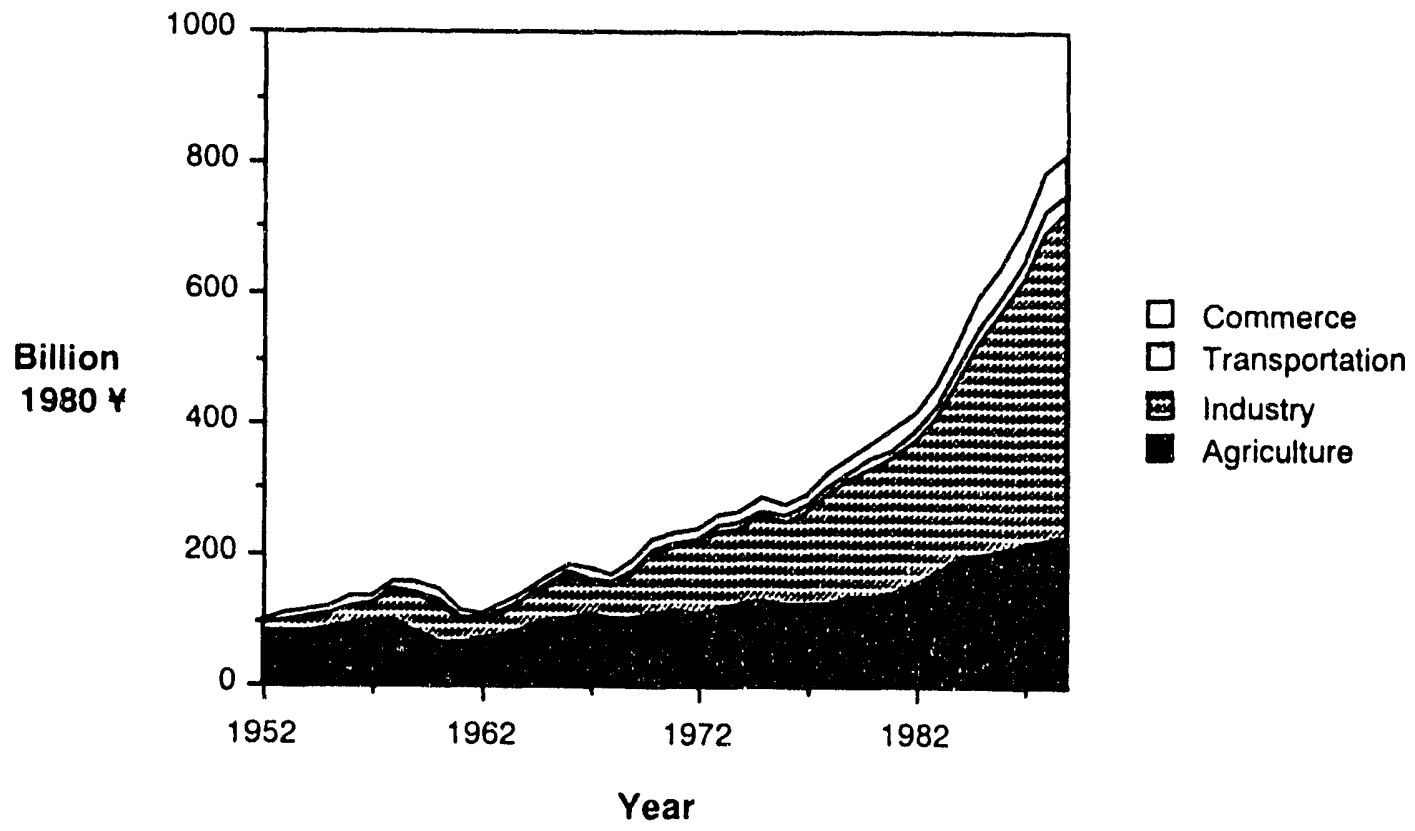

Source: China - Statistical Yearbook of China, 1990.

Note: Construction is included in Industry. 
4. Opportunities for improved efficiency abound

Energy is used inefficiently in all sectors in China. Energy-using equipment is often obsolete, and a shortage of investment capital constrains the introduction of more efficient technologies even if they would be cost-effective. In-plan energy supplies are priced below their long-run marginal cost, providing less incentive than appropriate not to waste energy. The inadequacy of central government supplies has reinforced the trend towards local, decentralized production and consumption, which tends to be more inefficient because, for example, rural mines are primitive and supply lower quality coal.

The Chinese government, realizing that energy will be a limiting factor to ambitious development plans, has, in the last decade, taken an increasing interest in energy conservation programs. Such programs have achieved great successes, although a large untapped conservation potential still remains.

Starting with the Sixth Five-Year Plan (1981-1985), the Chinese initiated a massive and ambitious program for investing in industrial energy conservation. This program has continued through the Seventh Five-Year Plan (1986-1990) and into the Eighth. At present, however, data are only available to assess the performance of conservation programs during the Sixth Five-Year Plan.

By 1985, these programs were saving an estimated 30 Mtce annually, reducing energy demand growth to $4 \%$ from what would have been $7 \%$. The substantial central government investment in energy-efficiency projects during the Sixth Five-Year Plan was, on average, significantly more costeffective than investment in energy supply projects and served to reduce the magnitude of energy shortages during those years [Levine and Liu, 1990]. The sources of these large energy savings are presented in detail in the section on industrial end use.

\section{B MACROECONOMIC INDICATORS \& ENERGY INTENSITY}

Energy consumption is closely interrelated with economic development. Economic activity both creates the demand for more energy and allows new supplies to be developed. One important aggregate measure of the energy performance of an economy is energy consumption per unit of national income. A brief discussion of the macroeconomy and measures of national output must be included as a part of our energy analysis.

\section{Measures of economic output}

There are two main measures of China's economic output. The State Statistical Bureau (SSB) compiles data on "national income" and the World Bank uses gross national (and domestic) product. The national income is the sum of the net outputs of the material sectors of the economy and is comparable to what the United Nations terms the "net material product" [World Bank, 1983]. At the urging of the World Bank, the SSB has recently begun to publish GNP/GDP figures that correspond to those of the World Bank. National income is about 20\% lower than GDP figures for two reasons: national income does not fully include the service sector, and national income subtracts depreciation. Unfortunately, because the SSB did not concentrate on collecting data on the service sector before the 1970s, the World Bank estimates for GDP begin in 1968, while the SSB publishes figures for national income since 1952. Figure ill.11 charts these figures by sector, providing a good overview of the structure and growth of the modern Chinese economy.

For an overall picture of growth and changes in the structure of the economy, the GDP measure is better because it includes consumption of fixed assets and includes the service sector. Furthermore, the growth rate of national income is approximately equal to the growth rate of GDP because, by the World Bank's own estimates, the GDP to national income ratio has remained fairly 
constant [World Bank, 1983; p. 267]. Experts agree that both national income and GDP statistics accurately reflect trends in the economy. These statistics were exaggerated during the Great Leap Forward (the late 1950s), so less confidence can be placed in the output data from this period.

When determining growth trends in sectoral energy intensities for China, another macroeconomic indicator, gross output value, is used. The gross output value differs from national income in that it double-counts intermediate outputs (it is not a valueadded measure - vertical disintegration will increase gross output value even if final output does not increase). Compare Figure III.12 with the previous figure. Despite the fact that gross output intensities will underestimate the "true" sector intensities calculated from the net output values, they are more likely to reflect the trends in sectoral energy intensities because the net output value to physical output ratio varies over time.

\section{Growth in income, 1952-1988}

Over the past 40 years, China has expanded its economy and industrial base at a very rapid rate. Since 1952, national income has increased 20 times in real terms. On a per capita basis, income has increased almost 11 times. Tremendous growth in the industrial sector during the economic reform period of the 1980s has firmly established industry as the most important sector in terms of both size and potential for future growth.

The real annual growth of $6 \%$ since 1952 has been marked by considerable fluctuations. Official data showed output rising dramatically during the Great Leap Forward (1958-59) and plummeting immediately afterward until, by 1962 , national income had fallen to the level of nine years prior. The Cultural Revolution again threw the country into disarray. Since then, growth has been uninterrupted. These trends and others are evident in Table III.1.

The energy intensity of the Chinese economy is reported in Figure III.12. Energy intensity has undergone major changes in the past 40 years. Before 1978, increasing energy intensity was due largely to the increasing share of industrial output, especially heavy industry. The peak around 1960 is due to the Great Leap Forward and mirrors the share trend between industry and agriculture. The more energy-intensive industrial sector boomed during this period, but collapsed in its aftermath, and much of this economic activity shifted to the less energy-intensive agricultural sector, again reducing the overall energy intensity of the economy. Data for energy end use by sector are unavailable for the entire period, so we cannot calculate how energy intensity would have changed had sectoral shares remained fixed at some base year or average level. However, the first peak is due largely to the structural change.

The recent reduction in the energy irtensity of the Chinese economy is attributed to several factors:

- a shift in the sectoral shares of the economy away from energy-intensive heavy industry;

- a large increase in conservation investment, especially in industry;

- substitution of inputs caused by shortages in some areas; and,

- an increase in imports of energyintensive products, especially steel and fertilizer.

If energy intensities had frozen at 1977 levels, the economy would have required an additional 500 Mtce of energy inputs to produce the same output in 1988. (See Figure III.13.)

Although significant progress has been made recently in reducing energy intensities, there still exists a huge untapped conservation potential in China's system of energy use, especially in the large industrial sector.

\section{ENERGY END USE BY SECTOR}

The State Statistical Bureau divides the Chinese economy into five sectors for energy and economic accounting: Agriculture, Industry, Construction, Transportation and 
Table III.1: Growth Rates and Energy Elasticities.

\begin{tabular}{cccc} 
Period & $\begin{array}{c}\text { Average Annual } \\
\text { Growth in National } \\
\text { Income }\end{array}$ & $\begin{array}{c}\text { Average Annual } \\
\text { Growth in Energy } \\
\text { Consumption }\end{array}$ & $\begin{array}{c}\text { Average Annual } \\
\text { Energy Elasticlty2 }\end{array}$ \\
\hline $1952-59$ & $6.4 \%$ & $26.1 \%$ & 4.1 \\
$1959-68$ & $0.9 \%$ & $-2.9 \%$ & -3.2 \\
$1968-79$ & $6.9 \%$ & $10 \%$ & 1.4 \\
$1979-88$ & $9.4 \%$ & $5.1 \%$ & 0.5 \\
$1952-88$ & $5.9 \%$ & $8.6 \%$ & 1.5
\end{tabular}

Source: Derived from data in Statistical Yearbooks of China , 1989.

2 The energy elasticity, $\varepsilon$, is calculated as the ratio of energy consumption growth and GDP growth, as follows:

$$
\varepsilon=\frac{\Delta \% \mathrm{E}}{\Delta \% \mathrm{GDP}}
$$

When this ratio is less than one, it indicates that energy consumption is growing slower than output, and thus the energy intensity of the economy is decreasing (assuming both are experiencing positive growth). When it is greater than one, energy intensity is increasing. This measure can be ambiguous during periods of decline in either energy consumption or output, such as 1959-68. Energy elasticity was negative during this period because many uneconomic coal mines opened during the Great Leap Forward were closed.

Commerce. Because the industrial sector is so important in China, we have examined it at the subsectoral level, grouping the subsectors by energy intensity. This sectoral disaggregation is summarized in Figure III.14.

The agriculture sector accounts for the value of all crops (including tea, fruits, tobacco etc.), forestry (not lumber), animal husbandry, fishing, and "miscellaneous" agricultural activities. The transportation sector also includes postal and telecommunications services. Commerce includes restaurants, shops, and hotels.

The grouping of industrial subsectors into energy intensive and non-energy intensive is intended to facilitate energy analysis. All unspecified industrial subsectors are lumped into miscellaneous, which are both energy intensive and non-energy intensive. Finally, in order to conform with international accounting standards, we lumped the construction sector into industry (under miscellaneous).

According to the disaggregation of the whole economy, the sectoral gross output value structure of the Chinese economy since 1952 is seen as in Figure III.15.

Industry's share has grown steadily at the expense of agriculiure's, as expected for a developing economy. Because industry is more energy-intensive, the importance of this sector in determining overall energy consumption is even larger than Figure III.15 suggests. Of the increase in energy consumption in China in this decade, more than $80 \%$ has come from industry. 
Figure III.12: National Income Energy Intensity, 1952-1988.

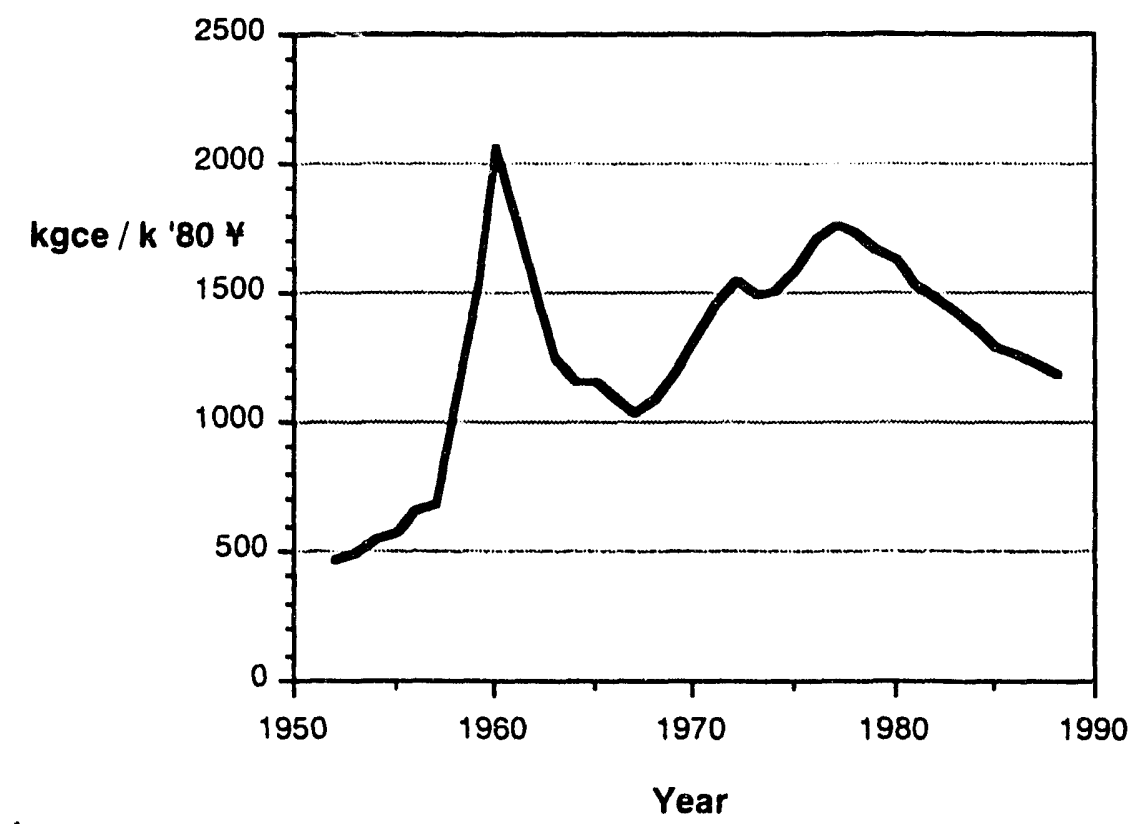

Source: Derived from data in Statistical Yearbooks of China, 1981-1989.

Figure III.13: Commercial Energy Consumption: Actual Use versus Predicted by National Income, 1952-1988.

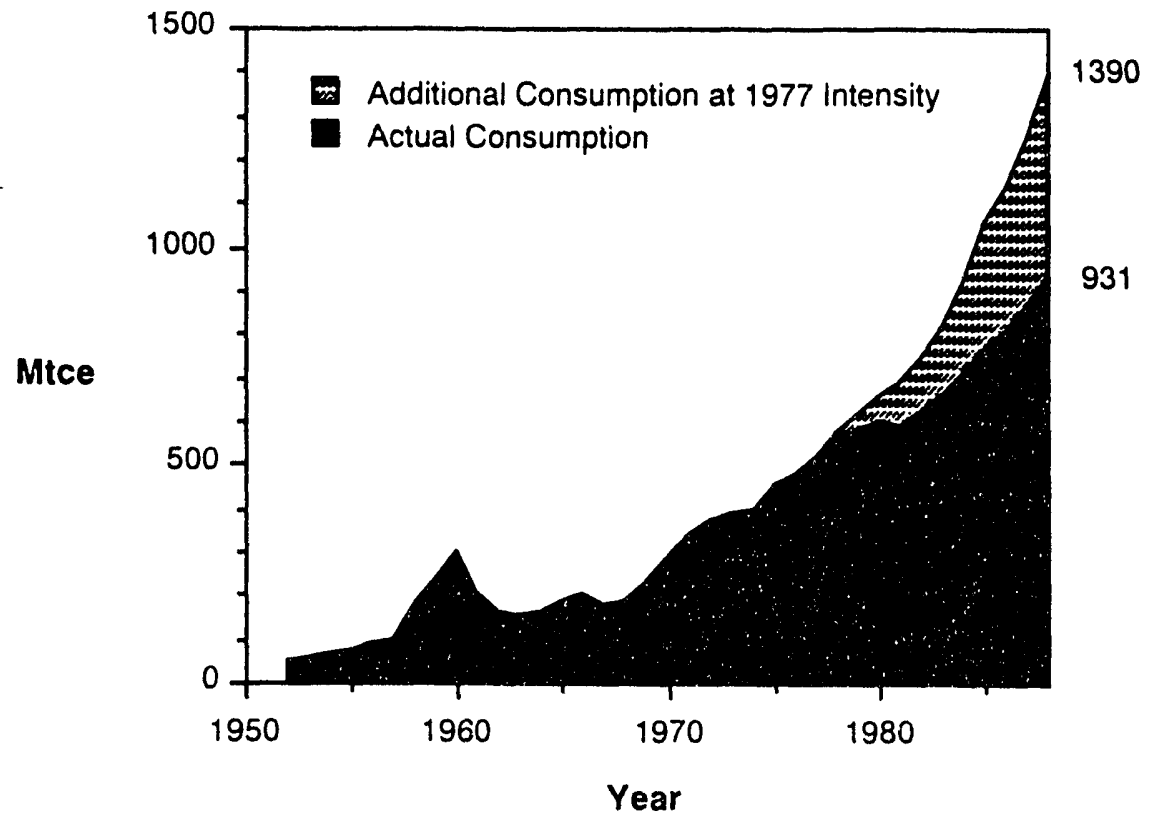

Source: Derived from Statistical Yearbook of China data, 1981-1989. 
Figure III.14: Sectoral Disaggregation of the Chinese Economy.

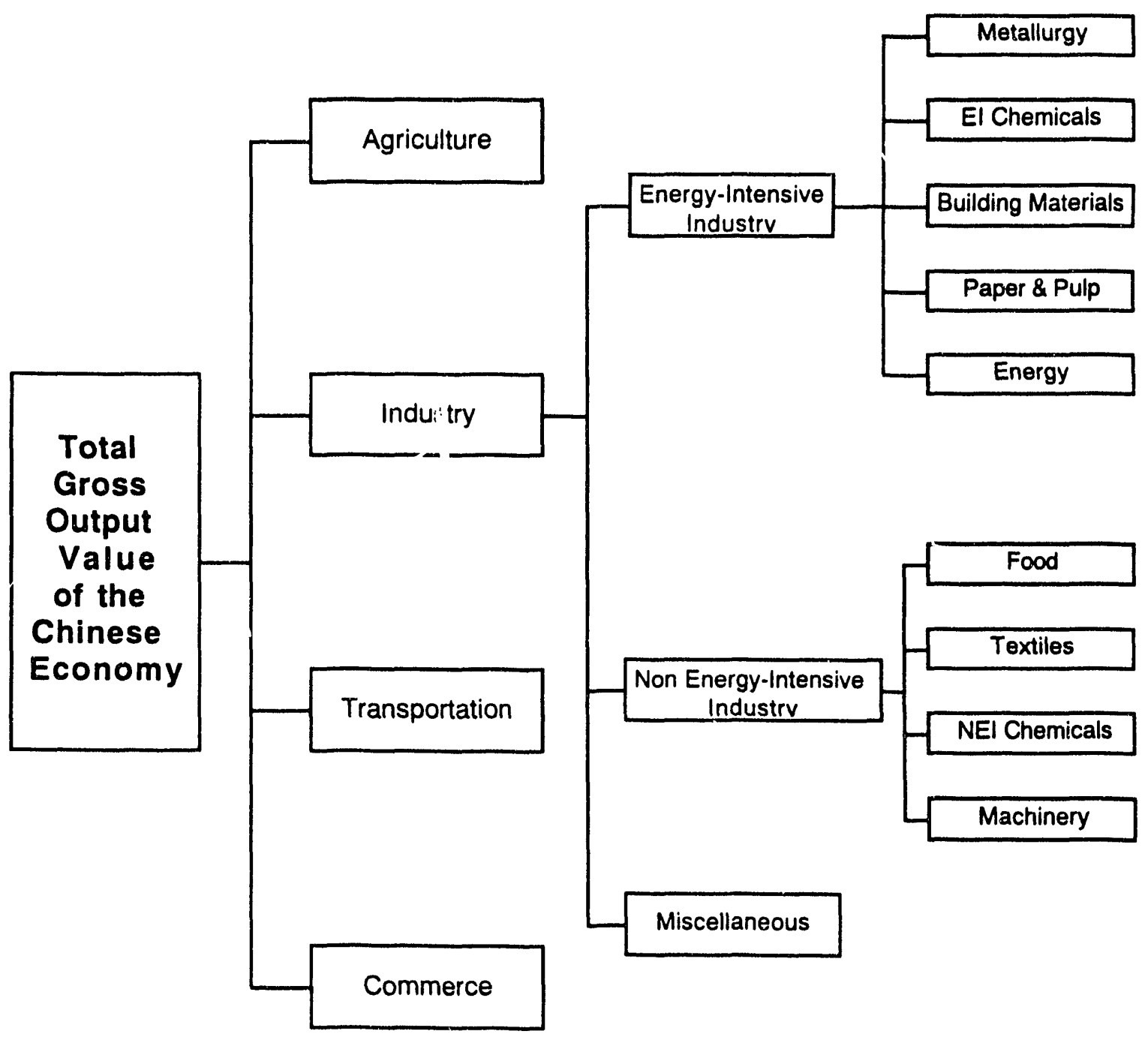

Note: Chemicals are divided into energy intensi:e (EI) and non energy-intensive (NEI). Construction is merged into industry. Energy industry, as defined by the SSB, includes coal mining and washing, coking and gasification, oil and gas extraction, refining, and electricity generation. 
Figure III.15: Sectoral Shares of Gross Output Value, 1952-1988.

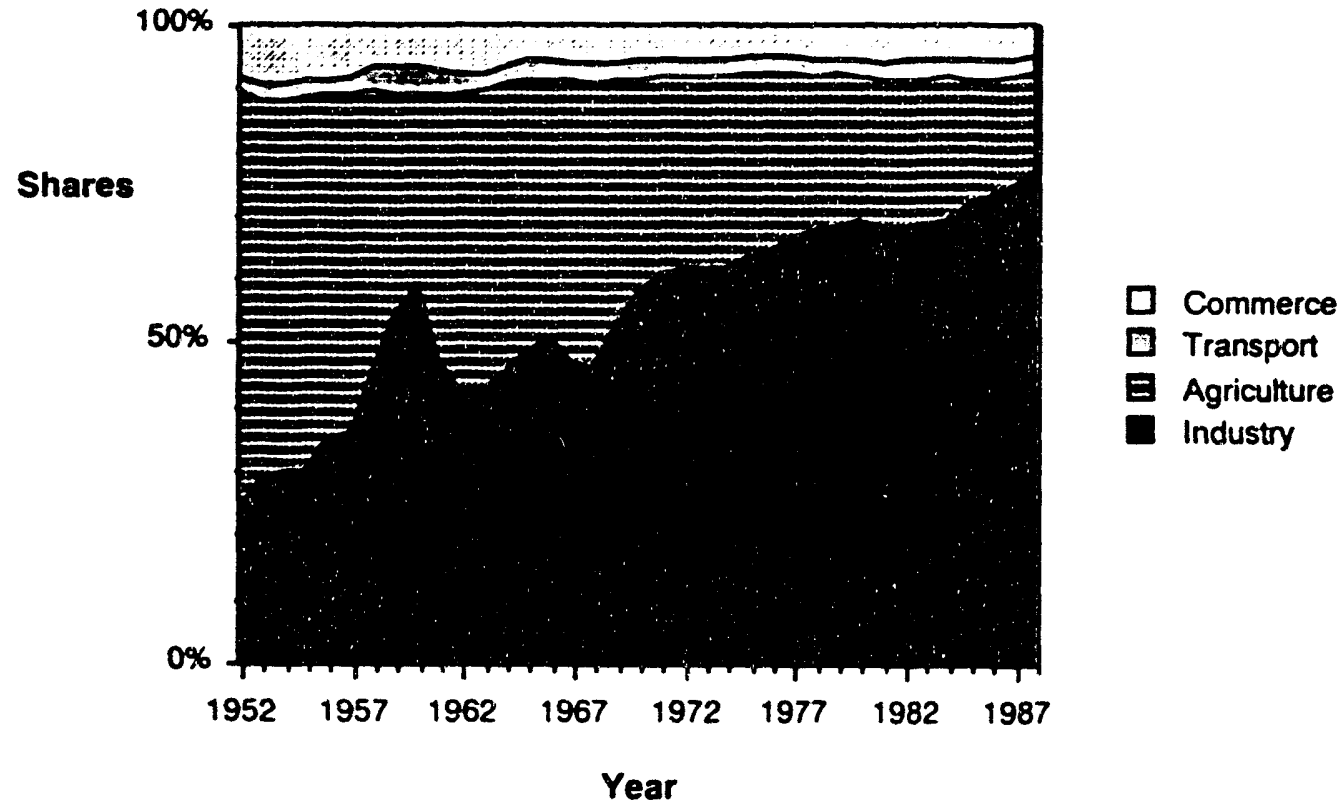

Source: Statistical Yearbook of China data, 1988.

The ratio of industrial energy use to gross output value (or energy intensity) has decreased more than in other sectors. This is evident in Figure III.16.

Industry has delivered the greatest decreases in energy intensity. Because industry has the largest share of total gross output and consumes most of the delivered energy, the overall energy intensity of the Chinese economy tends to track industry closely. The energy intensity of agriculture has not improved since 1984. The trend of energy intensity in commerce is difficult to explain, especially the precipitous drop between 1984 and 1985. A small, absolute change in either gross output value or energy consumption, unaccompanied by a change in the other, would produce a larger change in energy intensity in the commercial sector than it would in other sectors. Because the sector is small, the intensity results are also susceptible to small absolute variations in either of these values due to reporting changes or errors in the data. Due to increased capitalization and increased energy consumption as a complement, it is not unreasonable to expect this sector's energy intensity to have increased over this period, as is the case between every year except 1984-86.

The energy savings attributable to the decrease in energy intensities can be calculated. Figure III.17 shows the difference between actual energy end use and how much energy would have been used had energy intensities remained the same since 1980.

Because industry is by far the largest energy end user and has also realized the largest decreases in energy intensity, the largest savings have occurred in this sector. The area under the curve is the total energy saved for the entire period. These savings are presented in Table III.2. These "savings" are not necessarily real, but they serve to indicate the impact of intensity reduction. This assumption also holds for our later calculations.

Because industry is the most important sector, we begin our sectoral analysis here. Furthermore, we will examine industrial 
Table III.2 Cumulative Sectoral Energy Savings (Mtce), 1980-1988.

\begin{tabular}{ccccc} 
Agriculture & Industry & Transport & Commerce & Total \\
\hline 70.3 & 1481.6 & 76.1 & 9.1 & 1637.3
\end{tabular}

Source: Derived from data from the 1988 Statistical Yearbook of China and the Energy Statistical Yearbook of China, 1989.

processes and energy intensities in detail at the subsectoral level. This subsectoral analysis allows us to separate changes in industrial energy intensity brought about by changes in subsectoral shares from changes in subsectoral energy intensities. We will also describe any conservation potential in the necessary detail.

\section{INDUSTRY AND ITS SUBSECTORS}

1. Economic substructure and energy end use

Industry's large share of total energy consumption is a direct result of an enduring national strategy that has emphasized industrialization, especially heavy industry. From 1952 to 1988 , industry's share of national gross output value grew from $24 \%$ to $77 \%$. This share has therefore increasingly determined total energy consumption. In 1988, final energy consumption in the industrial sector was $\mathbf{5 5 0}$ Mtce, accounting for $65 \%$ of commercial energy end use. The fuel sources of this consumption are presented in Figure III.18.

Coal is dominant in all major subsectors. In 1988, coal (mostly unwashed and unsorted) made up $47 \%$ of industrial end-use energy. Unfortunately, the widespread use of unwashed, unsorted coal burned in old boilers plays a large role in reducing the

Figure III.16: Sectoral Energy Intensity Index, 1980-1988.

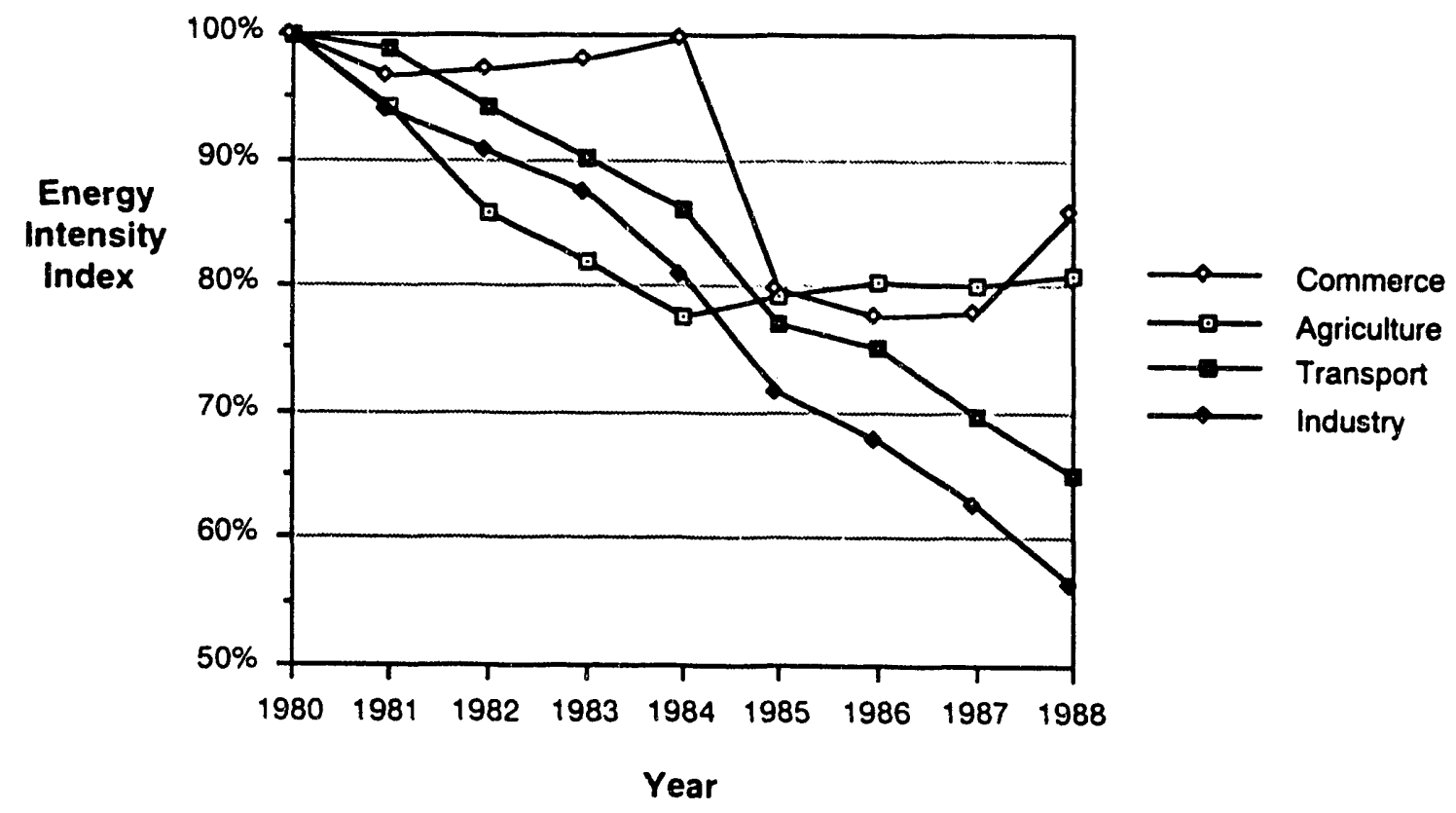

Source: Derived from data from the 1989 Statistical Yearbook of China and the Energy Statistical Yearbook of China, 1989.

Notes: Because it is impossible to adjust gross output value in the same manner as we have energy consumption, these energy intensity indices are calculated using unadjusted sectoral energy consumption. Trends should be little affected. 
overall energy efficiency of industry. Because coal consumption in Chinese industry is and will continue to be so important, improving coal utilization technologies must be a primary focus of energy planning and development in China.

Within the industrial sector, metallurgy, chemicals, building materials, and paper consume $59 \%$ of industrial end-use energy, while contributing only $28 \%$ to industrial gross output. Most of the products in these sectors are very energy-intensive.

Energy end-use in the industrial subsectors for the most recent years is reported in Figure III.19. These data are adjusted in the same manner as Figure III.14. Although we consider this data more accurate, we could not match it with gross output data (the subsector definitions are slightly different), and so must resort to data from an earlier period in the intensity analysis in the following section. Energy industry includes coal mining and washing, oil and gas extraction.

Shares have changed little, and total growth averaged $7 \%$ annually.

The energy use of the energy industry itself (which includes mining and extraction, refining and coking) is quite high in China, accounting for $14 \%$ of total industrial enduse. This high share is due to the size and the energy inefficiency of this subsector. The share of electricity self-use in Chinese power plants is also coincidentally $14 \%$ of total electricity generation.

\section{Figure III.17: Sectoral Energy Savings, 1980-1988.}

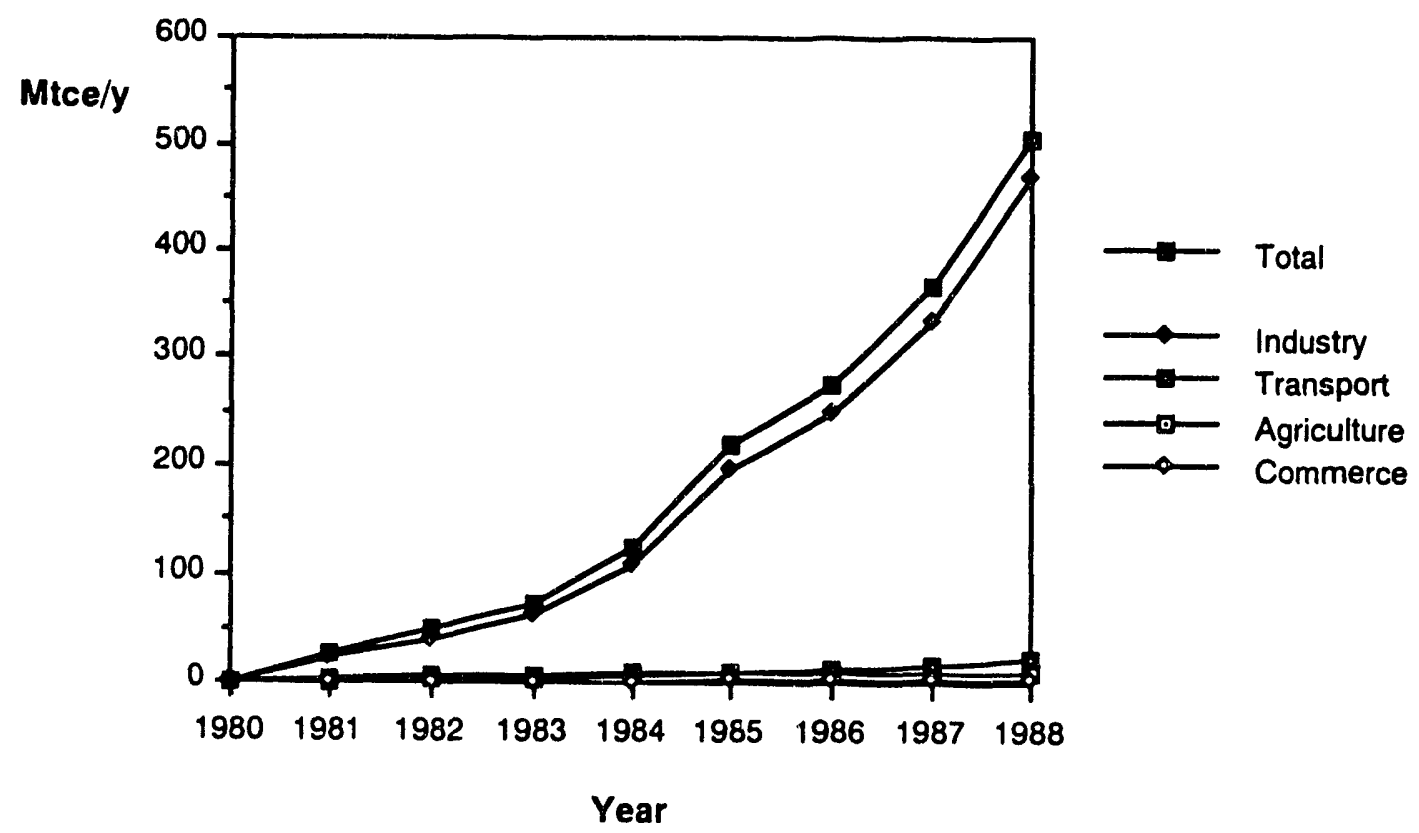

Source: Derived from data from the 1988 Statistical Yearbook of China and the Energy Statistics Yearbook of China, 1989.

Note: Sectoral shares are held constant at 1980 base year levels. It should be emphasized that these "savings" are calculated using gross output value, not national income as in Figure III.13. Industry includes village-level rura! industry. 
Figure III.18: Energy End Use in Industry by Source, 1980-1988.

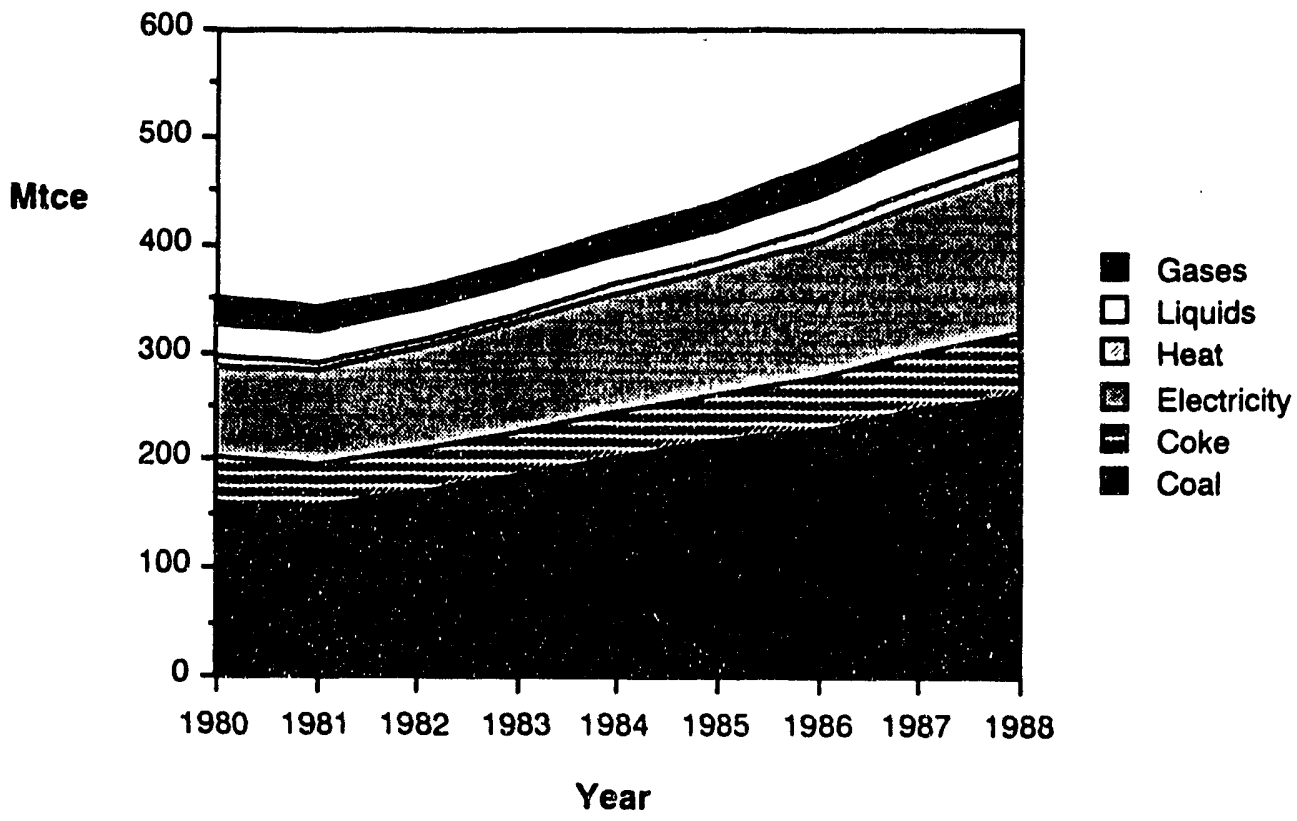

Source: Energy Statistical Yearbook of China, 1989.

Note: These data have been adjusted as described previously (supra Figure III.4).

Figure III.19: Energy End Use in Industry by Subsector, 1980-1985.

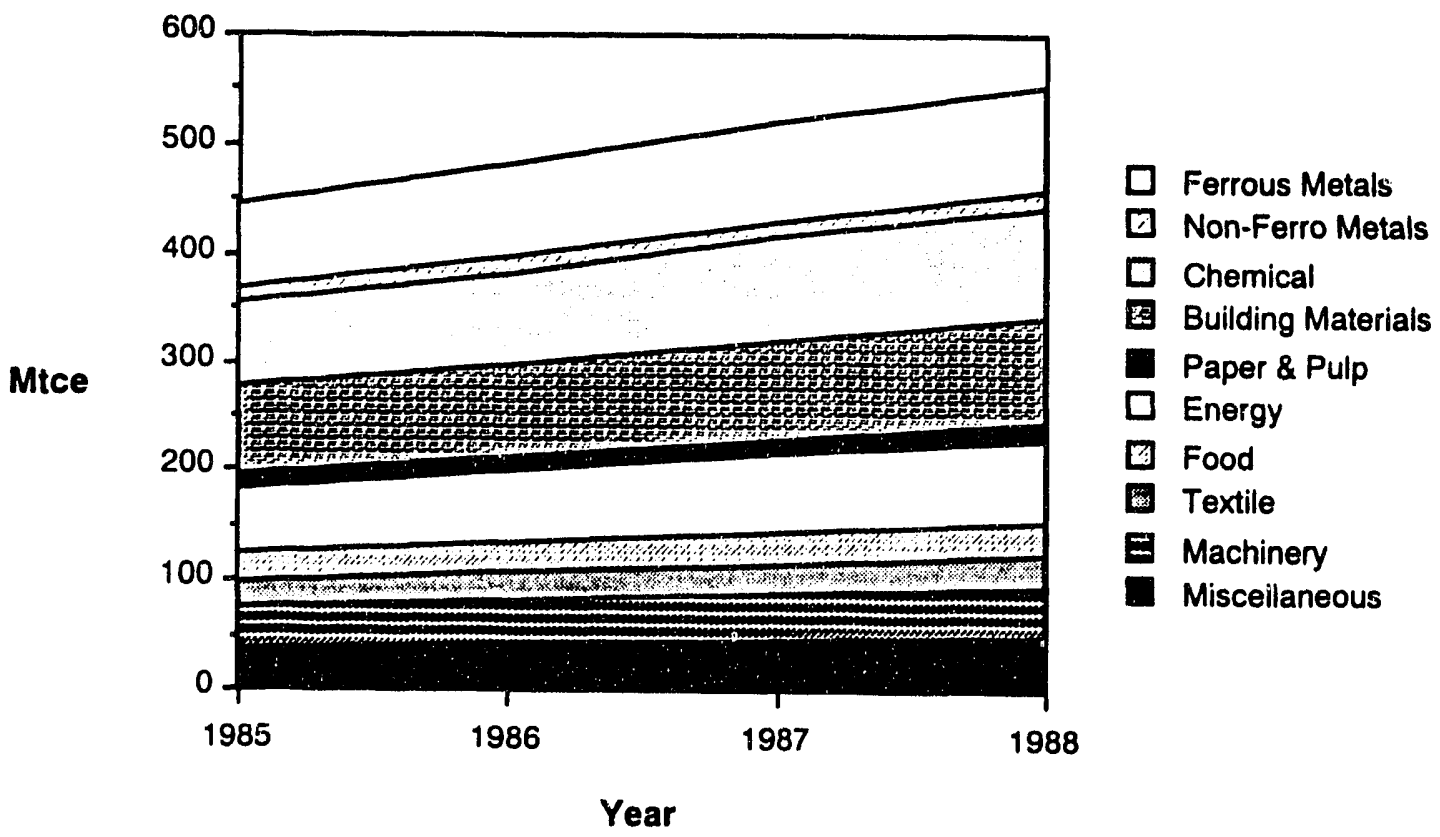

Source: Energy Statistical Yearbook of China, 1989. 
Figure III.20: Subsector Share of Industrial Gross Output Value, 1952-1988.

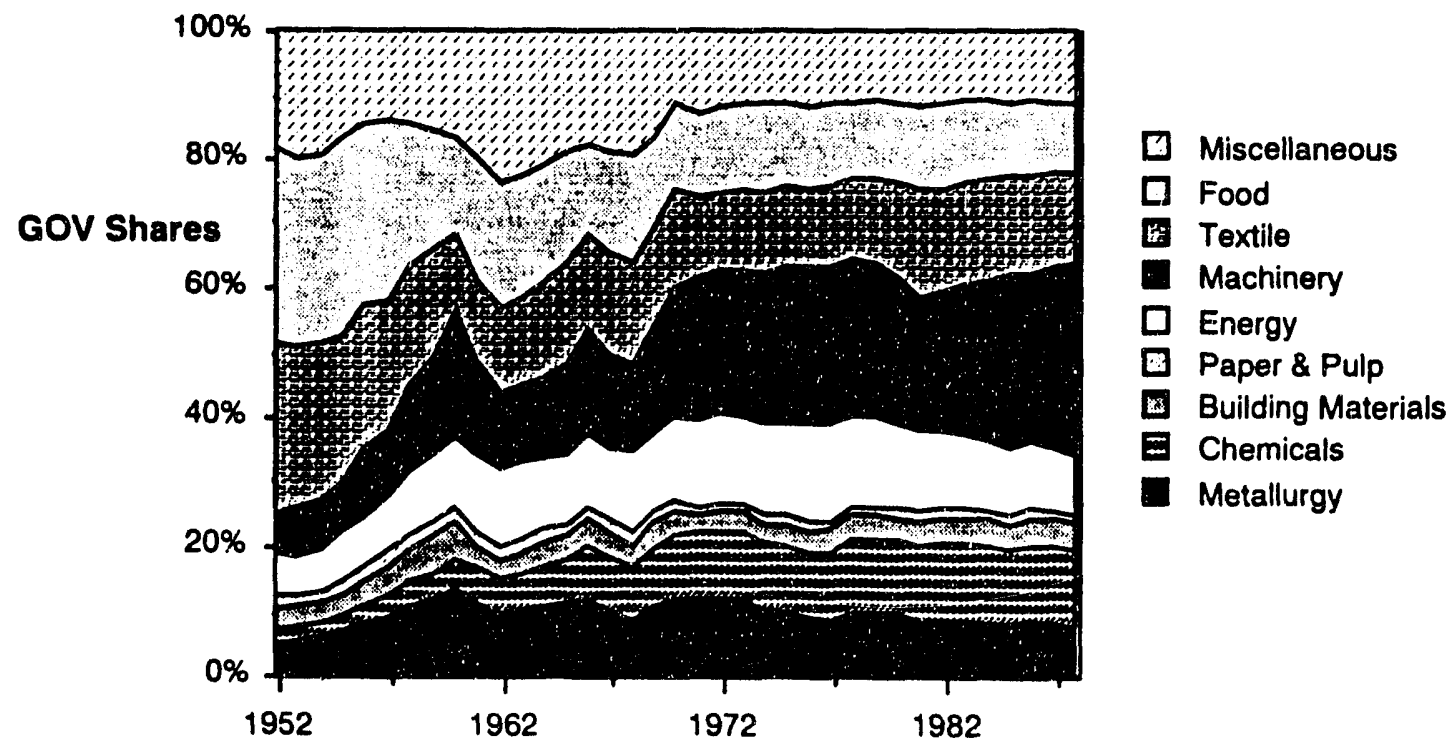

Source: Statistical Yearbook of China's Industrial Economy, 1988 and 1989.

Note: There are some small differences in the coverage of the GOV data in this figure and those in Figures III.18 \& 19. This figure excludes village level industries, which become increasingly important in the 1980s. The energy industry includes electricity generation. The construction sector is not included. Data for 1988 are estimated from growth rates. Gross output value of the "Miscellaneous" industries from 1952 to 1971 are not reported directly, but rather are calculated by deducting GOV of the specified sectors from the total industrial GOV.

Industrial subsectoral gross output value since 1952 is presented in Figure III.20.

The gross output value share of the three most energy-intensive industries, metallurgy, chemicals, and building materials, has changed little since 1970 . Therefore, the increasing energy intensity of industry as a whole in the 1970 s cannot be fully attributed to shifts toward these energy-intensive subsectors. It may be attributed in part to the increasing share of the machine-building industry. Not only is this industry more energy-intensive than those it is replacing, it indirectly propagates energy inefficiency by producing outdated machines.

Another important feature of China's industry is the large share of small enterprises in total industrial production. In 1988 , small enterprises accounted for $51 \%$ of total industrial gross output value [SSB, 1989c]. Small industries have the advantage of easy access to local economies, and labor-intensive methods. However, their inability to achieve economies of scale and their use of less advanced technologies handicap their efficiency. This is especially evident in all energy-intensive industries, which we will discuss further in later sections.

\section{Trends in energy intensities}

As we have already observed, industrial energy intensity has declined significantly in the last decade. In this section, we will examine industrial subsectors to better understand this trend.

The available data are less than ideal for analysis. Gross output data by industrial subsector for some recent years are available but are patchy for earlier years. End-use data are available at the level of disaggregation shown in Figure III.14 only since 1980, and we unfortunately were unable to reconcile several different data sources in order to complete the series for the last 


\section{Figure III.21: Adjusted Energy End Use in Industry by Subsector, 1980-1985.}

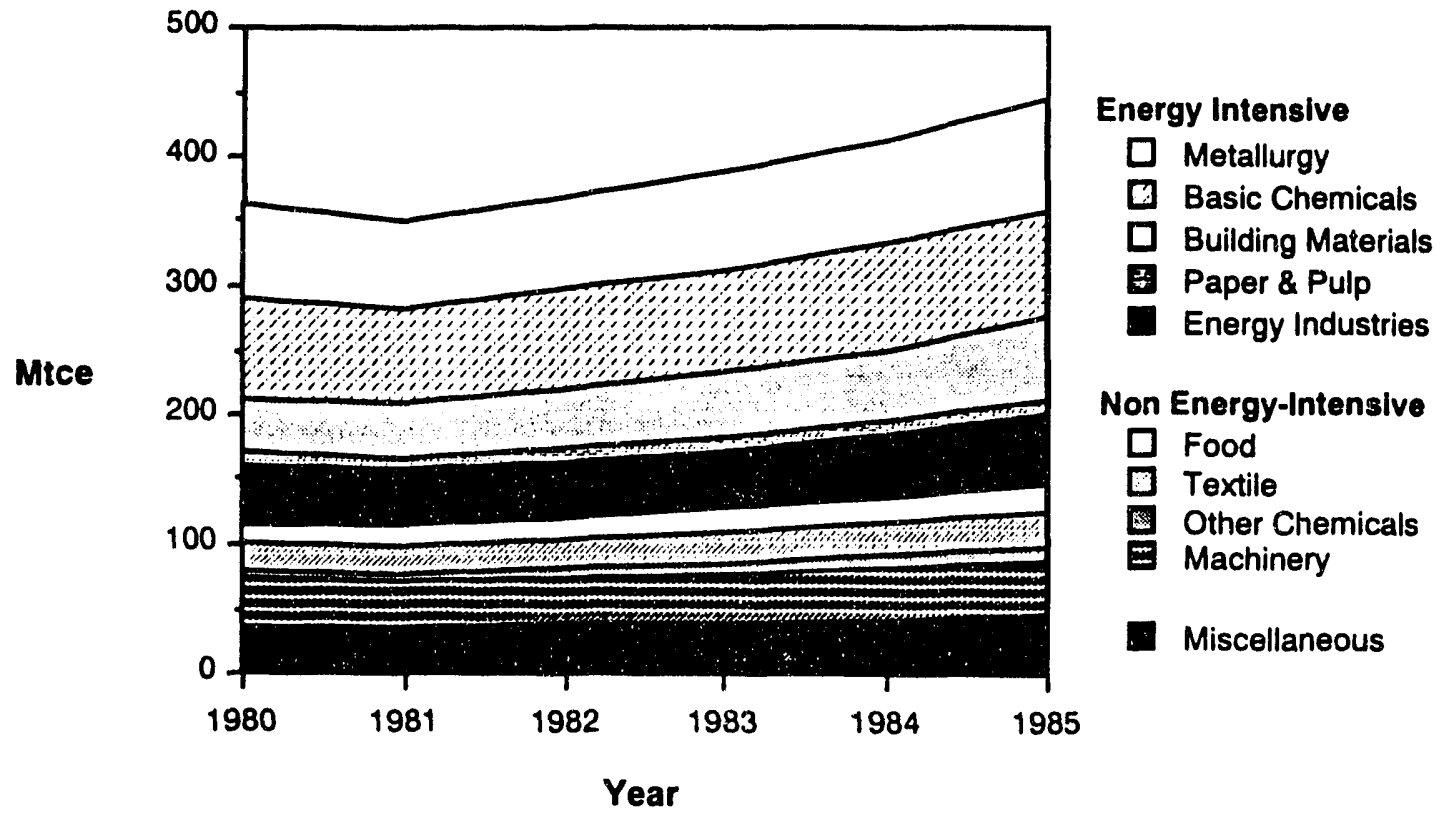

Source: Energy Statistical Yearbook of China, 1986.

decade. Only the data from 1980-1985 are currently consistent.

In order to use these data, we could not apply our adjustments to the original Chinese data because it would be impossible to adjust the gross output data in the same manner. There are three additional differences from the data reported in Figure III.19. The first is that village-level industries are not included. China is working to include village-level industries in its national accounts, but only energy data since 1985 include these. Second, the energy industry includes electric power generation since it is counted as part of industry in the Chinese accounting system. Finally, the construction sector is not included here. In spite of these differences, we still hold that these changes are relatively inconsequential to an analysis of the trends in subsectoral energy intensities. Unadjusted energy end use by industrial subsector for $1980-1985$ is reported in Figure III.21. ${ }^{3}$

3 In order to be consistent with gross output value data, we included the self-use of electric utilities in end-use; village-level industry is not
Although end-use data exist at this level of disaggregation for the entire decade, reporting methods changed in 1985, making the series difficult to reconcile.

Figure III.22 shows shares of gross output value for the three energy intensity categories of industry for the period we analyze in detail.

The subsectoral shares of GOV have changed little during this period, with the exception of the increasing share of the machine building industry, which increased the non-energy-intensive industries' share of GOV by about $5 \%$. Reductions in industrial energy consumption can be attributed largely to increases in energy efficiency. The absolute magnitude of these subsectoral energy intensities are reported in the Figure III.23.

Energy-intensive subsectors as a group use about six times as much energy per unit output as the non-energy intensive

included. The energy intensities of industrial subsectors in the following discussion are derived using this end-use data. 
subsectors. These energy intensities have changed significantly, even over the short period for which we have consistent data. Figure III.24 depicts these trends.

The non-intensive subsectors have realized the larger decreases in energy intensity. Because they account for a smaller share of total energy end use in industry, the energy savings in these industries are not as large as for the intensive subsectors. Because the machinery industry does have a large share of total GOV, however, it is the one exception in which an energy non-intensive subsector provides significant savings. Rather than reporting the savings by intensity grouping, these figures are provided by industry subsector. Figure III.25 reveals the sources of the decrease in energy intensity in the non-inte. isive group. The food subsector, like the agriculture sector, has not shown as sustained a decrease in energy intensity. Otherwise these industries have shown remarkable decreases in intensity, especially over such a short period.

The energy-intensive industries have not shown quite such dramatic decreases, although they are still substantial over so short a period.

As is evident in the Figure III.26, the basic chemicals industry has shown the largest decrease in energy intensity. The trend in the energy industry suggests that greater effort to improve efficiency could be made in this subsector.

Finally, before discussing the individual subsectors in detail, we can calculate the energy savings due to the decrease in energy intensities. Figures III.27 and III.28 show the difference between actual energy end use and how much energy would have been used had energy intensities remained the same since 1980. The industry subsectors are divided into energy-intensive and nonenergy intensive groups.

\section{Figure III.22: Industrial Subsectoral Shares of Gross Output Value, 1980-1987.}

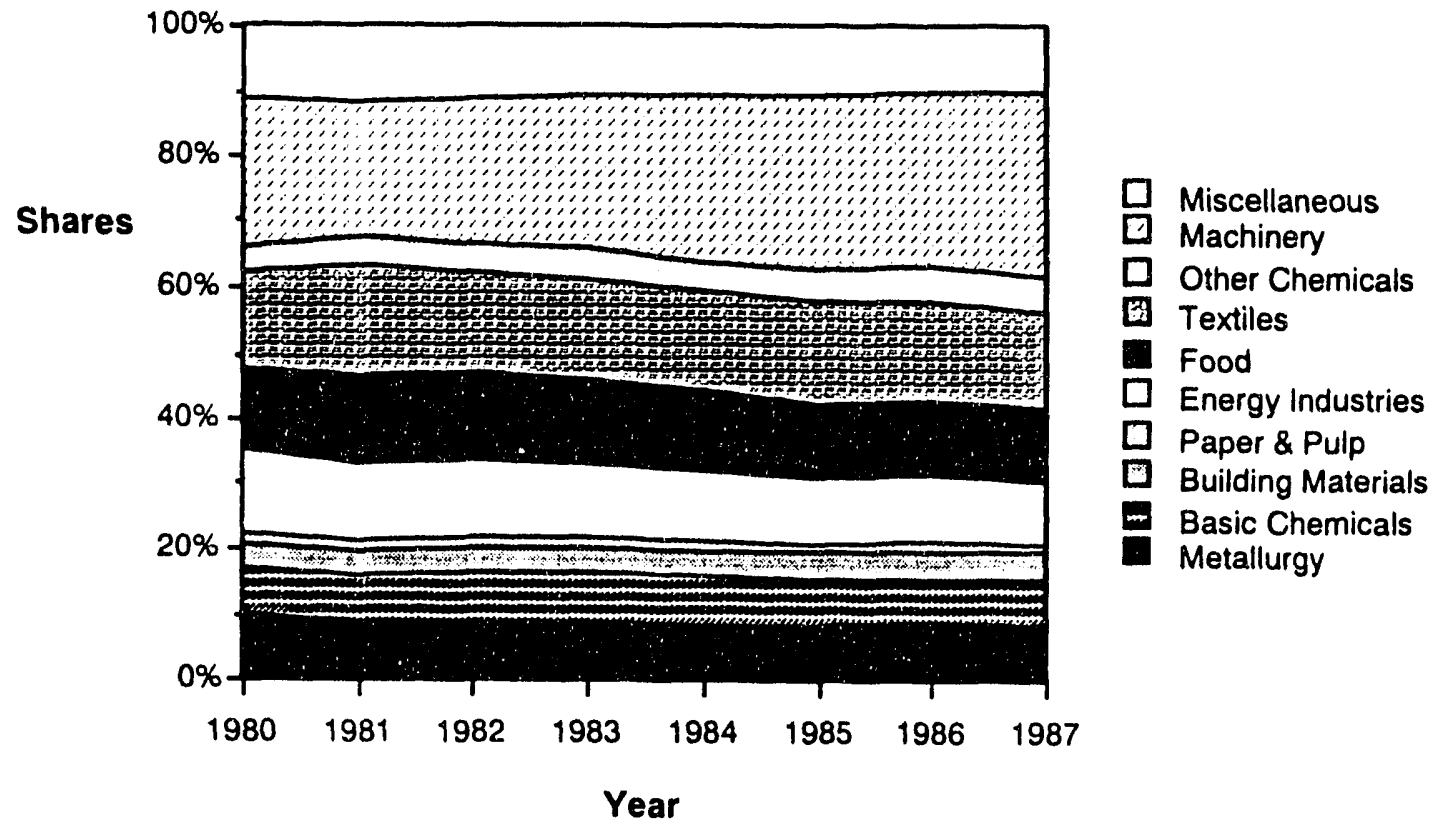

Source: Statistical Yearbook of China's Industrial Economy, 1988. 
Figure III.23: Industry Subsector Energy Intensities, 1985.

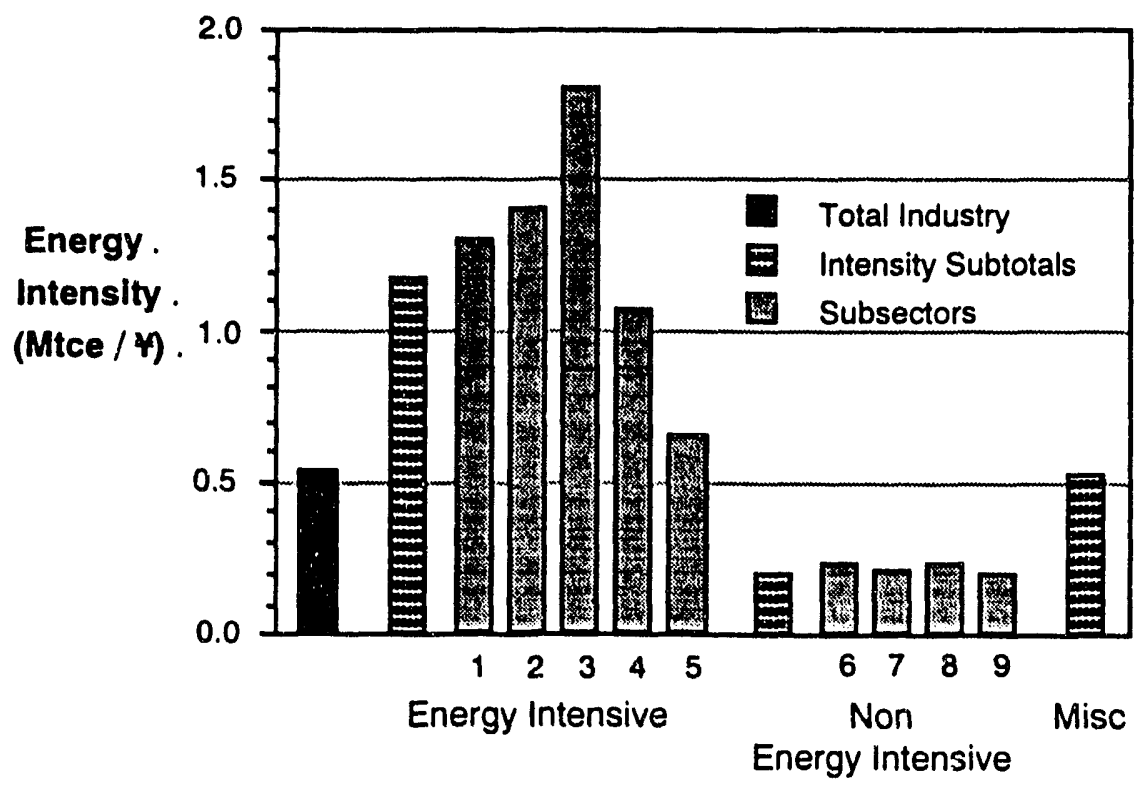

Notes: $\quad$ Sectors are as follows: 1 - Metallurgy; 2 -Industrial Chemicals; 3 - Building Materials; 4 -Paper and Pulp; 5 - Energy Industries; 6 - Food; 7 -Textiles; 8 - Household Chemicals; 9 -Machinery.

Figure III.24: Industry Energy Intensity Indices, 1980-1985.

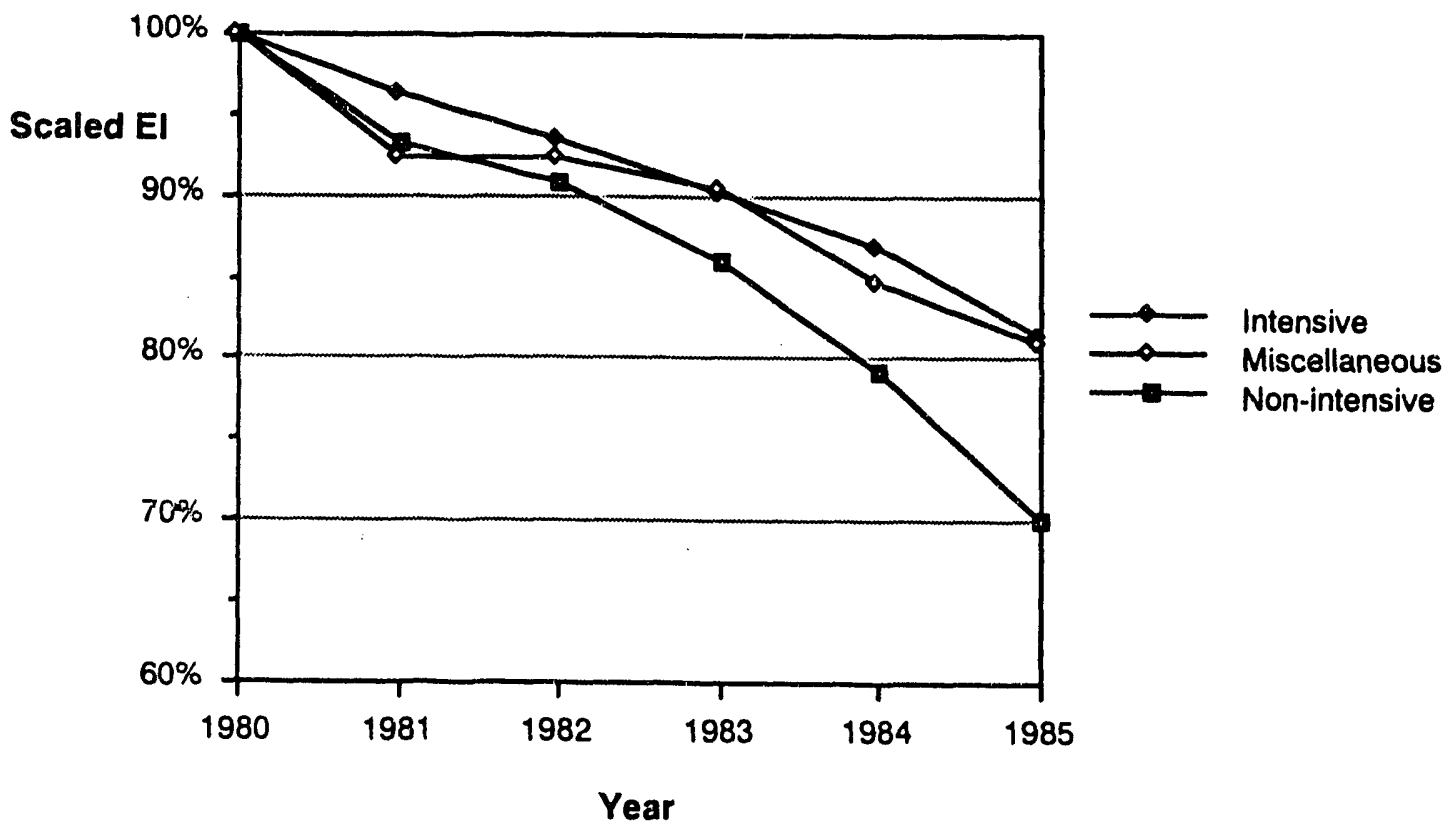
Source: Derived from data from the 1988 Statistical Yearbook of China and the Energy Statistics Yearbook of
China, 1986. 
Figure III.25: Energy Intensity Indices, Energy Non-Intensive Industries, 1980-1985.

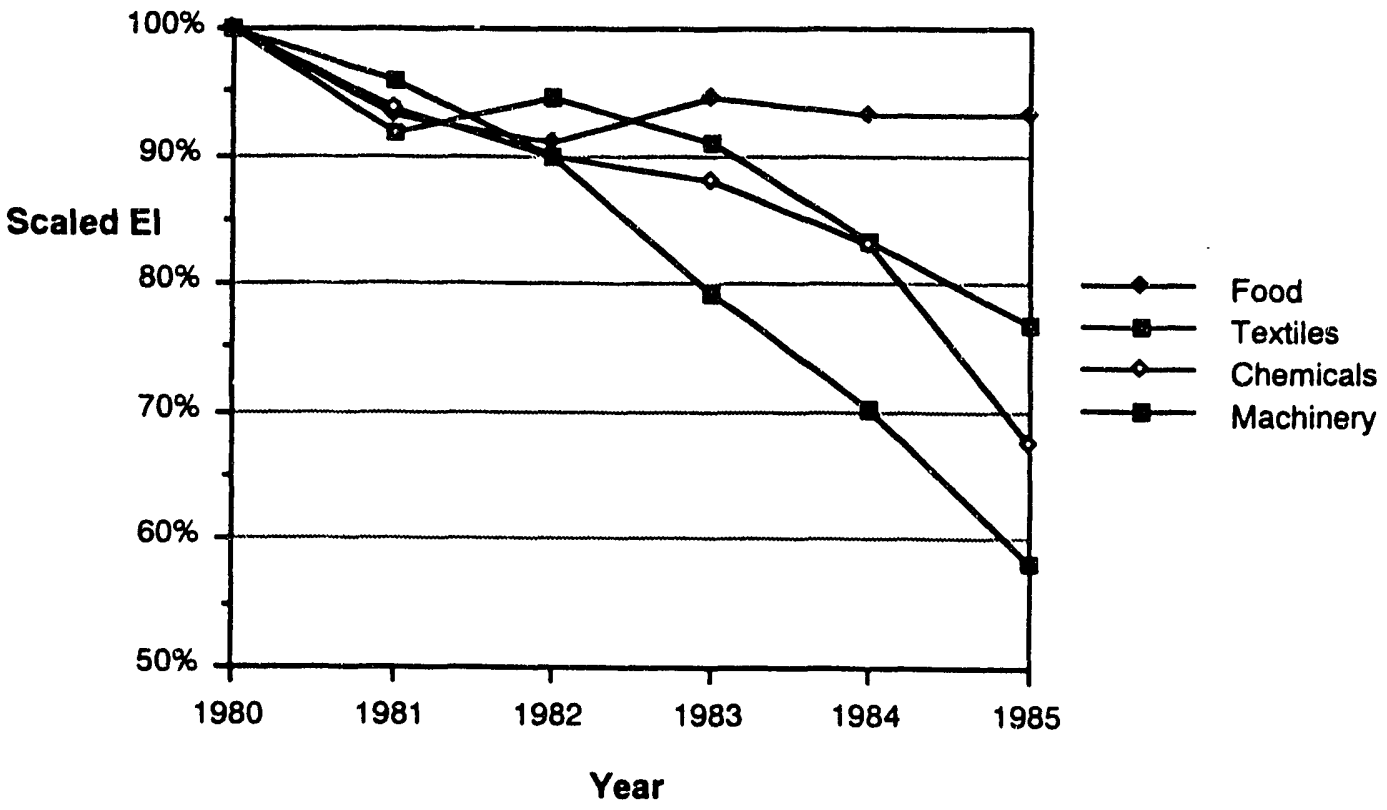

Source: Derived from data from the 1988 Statistical Yearbook of China and the Energy Statistics Yearbook of China, 1986.

Figure III.26: Energy Intensity Indices, Energy Intensive Industries, 1980-1985.

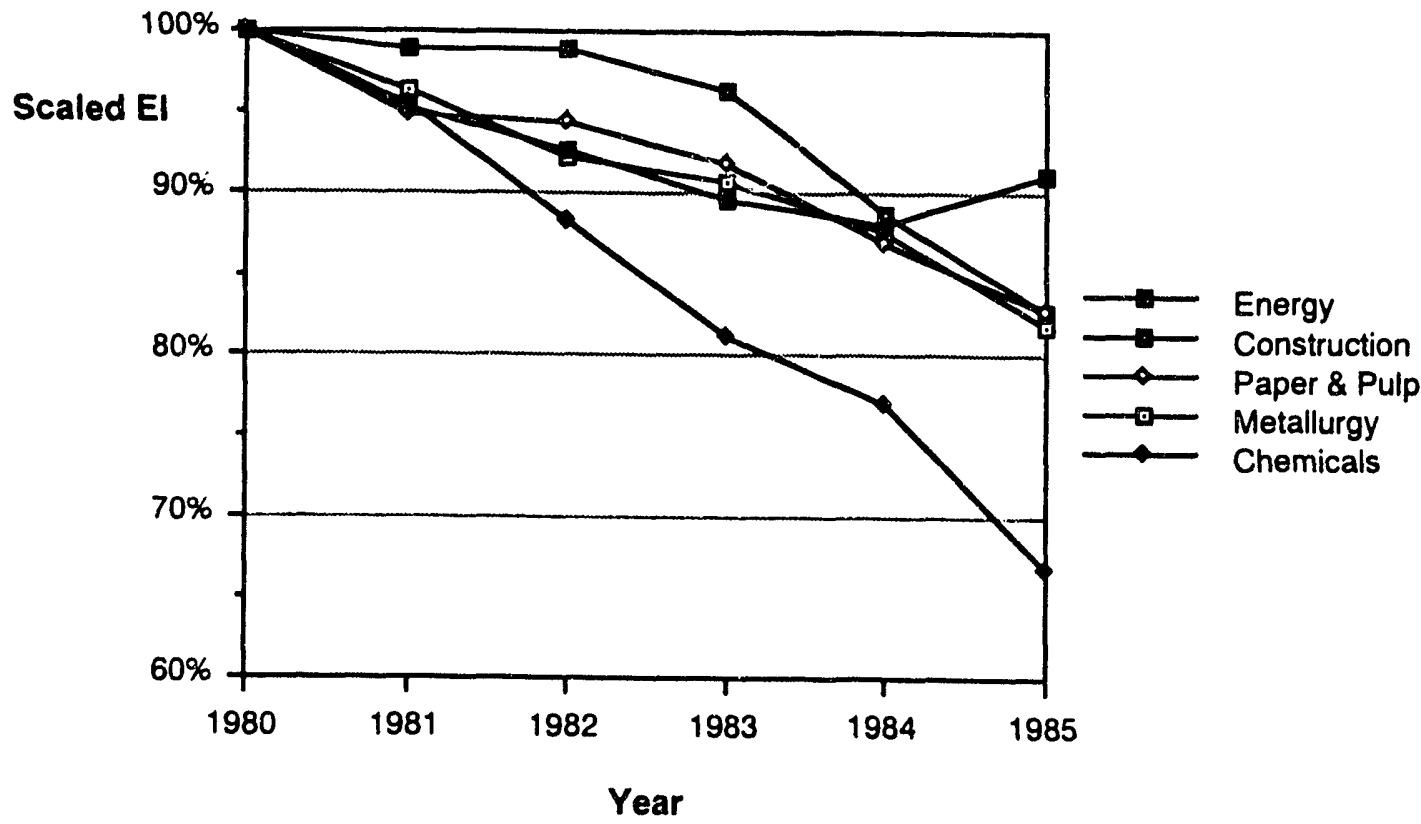

Source: Derived from data from the 1988 Statistical Yearbook of China and the Energy Statistics Yearbook of China, 1986. 
The savings depend on the reductions in energy intensity within the subsector and the subsectoral shares of total energy consumption. For example, as much energy is consumed in the metallurgical industry as in the chemical industry, but the intensity reduction in the latter industry has been much larger, so its share of savings is larger also. In contrast, the energy shares of the construction (or building materials) and energy industries are almost the same, but savings in these industries have differed because energy intensities have differed.

This relationship also applies between energy-intensive and non-energy intensive industries. Compare Figure III.28 with the previous one (III.27).

Savings in the machinery industry are so large not because it is a large consumer of energy (it is a medium consumer compared with other subsectors $-9.6 \%$ of total industrial energy consumption in 1985) but because it has experienced the largest declines in energy intensities during this period. Otherwise, the non-energy intensive sectors are less important in total energy savings.

The cumulative energy savings in industry over this period are reported in Table III.3.

The largest savings have been realized in the basic chemicals industry. Metals (mainly steelmaking) are also very important, because much of the technology is obsolete and there still exists a very large untapped conservation potential. The machinery industry, despite the fact that it is nonenergy intensive, shows substantial energy savings.

The non-energy intensive sectors, with the exception of the machinery industry, are relatively unimportant because of their small shares of total end-use in industry. Consequently, they will nut be discussed in detail. The energy-intensive industries, however, are very important in determining overall energy consumption in China and merit closer attention.

\section{Figure III.27: Energy Savings in Enargy Intensive Industries, 1980-1985.}

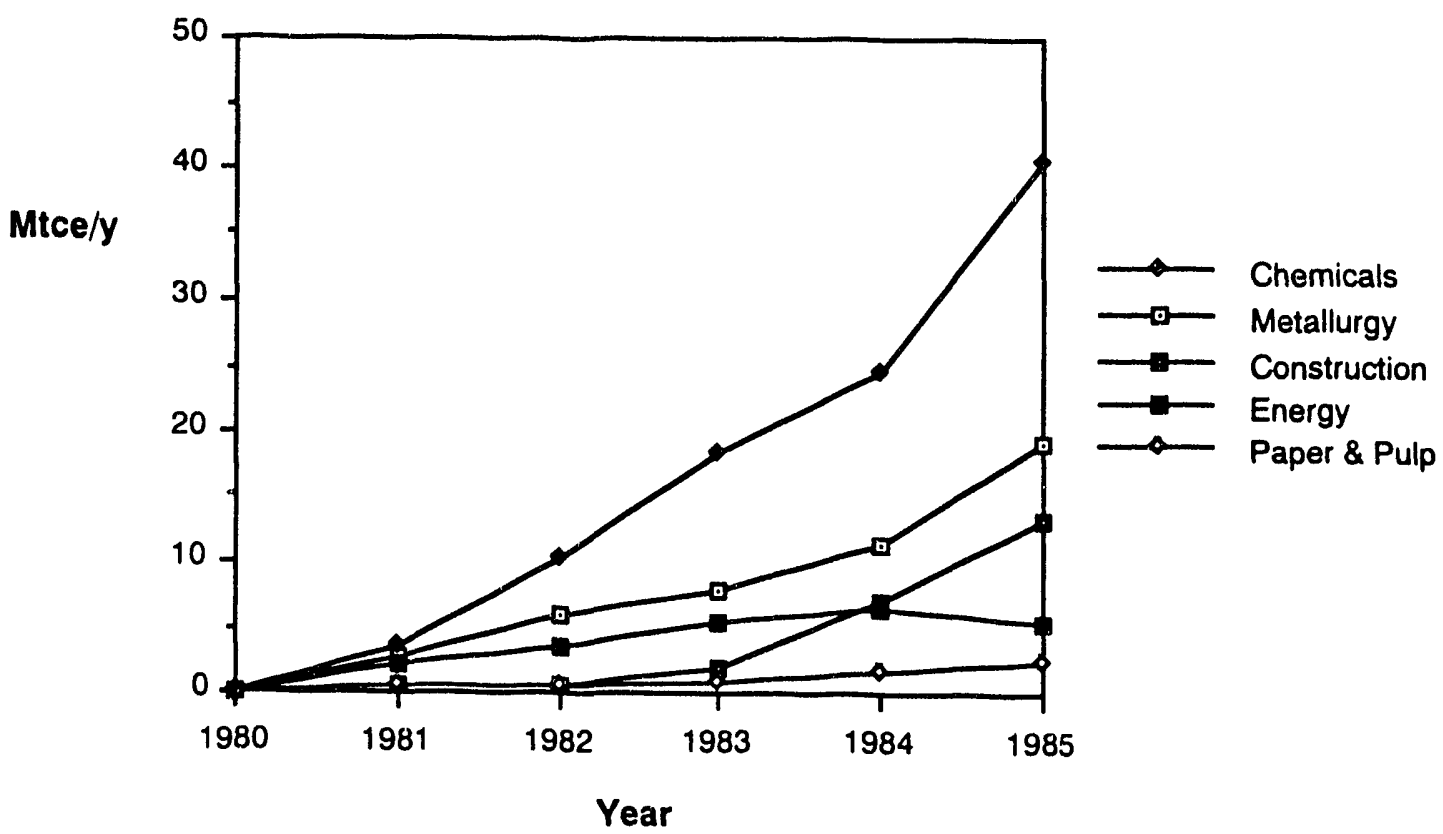

Source: Derived from data from the 1988 Statistical Yearbook of China and the Energy Statistics Yearbook of China, 1986. Industry does not include village level rural industry, unlike Figure III.17 and Table III.2. 
Figure III.28: Energy Savings in Energy Non-Intensive Industries, 1980-1985.

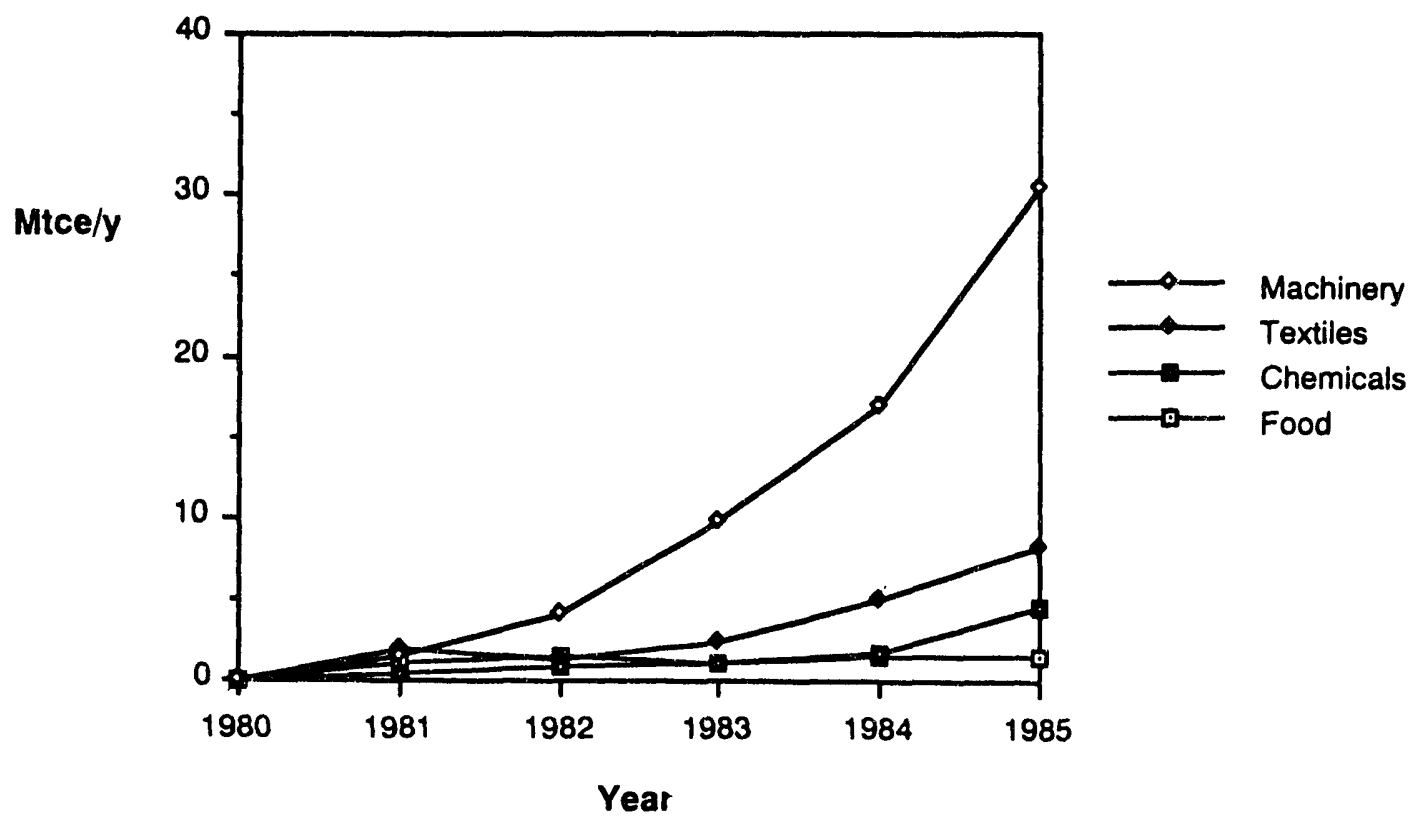

Source: Derived from data from the 1988 Statistical Yearbook of China and the Energy Statistics Yearbook of China, 1986.

Table III.3: Total Energy Savings by Subsector, 1980-1985. Industry Savings (Mtce)

\begin{tabular}{lc}
\hline All Industry & 321.68 \\
Energy Intensive Industries & 196.47 \\
Metallurgical & 47.12 \\
Basic Chemicals & 97.01 \\
Building Materials & 23.26 \\
Paper \& Pulp & 5.83 \\
Energy Industries & 23.24 \\
Non-energy Intensive Industries & 96.91 \\
Food & 6.78 \\
Textile & 18.70 \\
Other Chemicals & 8.77 \\
Machinery & 62.66 \\
Miscellaneous & 28.30 \\
\hline
\end{tabular}




\section{Industry subsectors: metallurgy}

The metallurgical industry is dominated by ferrous metals manufacturing. More than $95 \%$ of output (in tonnage) is from the steel industry. Energy consumption in 1988 was 94.45 Mtce for ferro metals and 16.86 Mtce for non-ferro metals. Total consumption in metallurgy accounted for $20 \%$ of industrial energy end-use and about $16 \%$ of industrial electricity consumption [SSB, 1989c]. Since data are readily available in the steel industry, which is also by far the most important, we will concentrate our discussion in this area.

China produced 47 million tons of steel products and 13 million tons of casting pig iron in 1988, consuming 94 Mtce of energy [Metallurgical Industry Press, 1989]. About $30 \%$ of all steel products were from medium and small factories, which used $70 \%$ more energy per unit output than the key factories. Overall energy intensity of China's steel products was about 2 tce per ton in 1988.

The Chinese figure must be modified before it can be compared to those of other nations in order to adjust for accounting differences. This figure includes non-steelmaking energy consumption not counted in the US or Japanese energy-intensity figures. Mining energy, energy used in production refractories, and "living" energy, such as cooking fuel in foundry cafeterias, are all incorporated into this figure in China, but not in the US. The production structure also differs; Chinese steel industry produces much more casting pig iron than the US and Japan.

These factors are accounted for in Table III.4, which applies the necessary adjustments the Chinese energy intensity figure for steel in order to allow comparison with other countries. The adjusted total energy intensity of steel (the average of the above results weighted by the product shares) is 1.45 tce per ton. This figure is $35 \%$ more than that of the comparable US industry, and the difference with Japan is even greater. Even key plants are significantly less energ, $y$ efficient than in the industrialized countries. This high-energy intensity can be attributed to several factors. While American and especially Japanese steel plants are highly integrated, only $40 \%$ of steel products in China are from integrated plants. Energy used in remelting and reheating adds to Chinese energy intensity. Chinese use lower quality ore than the US and Japan, and have not yet widely applied the technology to enrich the raw materials. The Chinese industry consumes less scrap iron, because less is available. Finally, and perhaps most tellingly, the Chinese steel industry is based largely on Soviet technology from the 1950s left over from the Great Leap Forward movement [Ross and Liu, 1990]. In the early 1980 s, the steel industry was the first target of the energy conservation campaign. Western technologies were used widely in retrofits. The overall energy intensity of crude steel declined from 2.04 tce/ton in 1980 to 1.64 tce/ton in 1989 , a $2.5 \%$ annual reduction rate [Metallurgical Industry Press, 1990].

To better understand the current inefficiencies, we should examine a breakdown of the industrial processes. Ironmaking is the most energy-intensive stage of steel production. In the US, ironmaking requires $780 \mathrm{kgce} / \mathrm{ton}$; in China the ratio is higher, at $882 \mathrm{kgce} / \mathrm{ton}$. This higher ratio is due to several factors. The Chinese production technique usually uses sinters as opposed to pellets. Sinters require five times as much energy and are often inadequate for use in large blast furnaces. The capacities of Chinese blast furnaces are lower, averaging 900 cubic meters for key plants, and only 300 cubic meters overall. This compares with the American national average of 1500 cubic meters, and the Japanese of 2300 cubic meters. The byproducts of blast furnace fuels are not well utilized in China. Also, there is a high proportion of electricity use and a wider use of "antique" coke (coke made from a primitive coke oven), with lower heat content than metallurgical coke. These factors contribute to the high energy intensity of Chinese ironmaking.

In a direct comparison, China appears to fare better in the steelmaking stage, at 100 $\mathrm{kgce} /$ ton vs. $99 \mathrm{kgce} /$ ton for the US. In a few respects, this close equivalence is accurate. For example, in the US a higher proportion of 
Table III.4: Energy Intensity Adjustments for Chinese Steel.

\begin{tabular}{lccc} 
& Key Plants & $\begin{array}{c}\text { Medlum \& } \\
\text { Small Plants }\end{array}$ & All Plants \\
\hline A. Total primary energy consumption & $50.77 \mathrm{Mtce}$ & $32.63 \mathrm{Mtce}$ & $83.40 \mathrm{Mtce}$ \\
B. Steel mill products & $27.62 \mathrm{Mt}$ & $14.96 \mathrm{Mt}$ & $42.58 \mathrm{Mt}$ \\
C. Unadjusted energy intensity & $1838 \mathrm{kgce} / \mathrm{t}$ & $2181 \mathrm{kgce} / \mathrm{t}$ & $1959 \mathrm{kgce} / \mathrm{t}$ \\
D. Commercial pig iron & $2.6 \mathrm{Mt}$ & $10.06 \mathrm{Mt}$ & $12.66 \mathrm{Mt}$ \\
E. Crude steel & $40.46 \mathrm{Mt}$ & $12.23 \mathrm{Mt}$ & $52.69 \mathrm{Mt}$ \\
F. Adjusted steel mill products & $33.58 \mathrm{Mt}$ & $9.00 \mathrm{Mt}$ & $42.58 \mathrm{Mt}$ \\
G. Energy adjustment for commercial pig iron & $2.89 \mathrm{Mtce}$ & $11.17 \mathrm{Mtce}$ & $13.93 \mathrm{Mtce}$ \\
H. Energy adjustment for finishing instead of & $1.2 \mathrm{Mtce}$ & $-1.2 \mathrm{Mtce}$ & $0.0 \mathrm{Mtce}$ \\
$\quad$ shipping ingots and rough shapes & & & \\
I. Energy adjustment for making other products & $3.7 \mathrm{Mtce}$ & $0.0 \mathrm{Mtce}$ & $3.68 \mathrm{Mtce}$ \\
J. First adjusted energy intensity & $1352 \mathrm{kgce} / \mathrm{t}$ & $2251 \mathrm{kgce} / \mathrm{t}$ & $1545 \mathrm{kgce} / \mathrm{t}$ \\
K. Estimated "living" energy & $20 \mathrm{kgce} / \mathrm{t}$ & $20 \mathrm{kgce} / \mathrm{t}$ & $20 \mathrm{kgce} / \mathrm{t}$ \\
L. Estimated mining energy & $4 \%$ & $1 \%$ & $5 \%$ \\
M. Final adjusted energy intensity & $1279 \mathrm{kgce} / \mathrm{t}$ & $2209 \mathrm{kgce} / \mathrm{t}$ & $1449 \mathrm{kgce} / \mathrm{t}$
\end{tabular}

Notes: Total primary energy consumption is calculated as $3.3 \times$ electrical energy + fuel energy. D does not include pig iron from steel furnaces. F differs from $B$ because some shipping between Key plants and Small and Medium plants is accounted for. The total steel output is the same. The yield of steel mills (for $F$ ) is estimated at .83 for key plants. $G$ is calculated with a casting pig iron energy intensity of 1.11 tce/t. $H=.2(F-B) . I$ includes alloys, refractories and carbon materials. $J=(A-G+H-I) / F$. $M=(J-K) \times(1-L)$.

Source: Marc Ross and Feng Liu, The Energy Efficiency of the Steel Industry in China.

furnaces are electric arc furnaces $(38 \%$ vs. $13 \%$ ). However, Chinese arc furnaces are $20 \%$ more energy-intensive than those in US, and $69 \%$ more than in Japan. Low unit capacity leads to higher energy consumption per unit output. More than $20 \%$ of steel made in China still uses open hearth furnaces, a technology abolished in the US and Japan. The continuous casting ratio is $13 \%$, far below the $61 \%$ and $92 \%$ in the US and Japan respectively. Non-integration of steel plants requires shipping of pigs (6.5 million tonmiles in 1987), requiring extra energy for transporting and remelting the pigs. Rough shapes are shipped to mills for shaping, which again incurs additional energy costs in transport and reheating. All these factors leave large opportunities for further reducing the energy intensity in Chinese steelmaking [Ross and Liu, 1990].

Since the beginning of economic reconstruction in 1952, the government has emphasized steel self-sufficiency. After $\mathbf{4 0}$ years steel products are still in short supply. Imports provide one quarter of the nation's consumption. The large industry is energy-inefficient and has poor quality output. As of 1987 , only $18 \%$ of domestic steel products were produced according to international standards [Metallurgical Industry Press, 1988]. Quality problems create inefficiencies in other sectors as well. Modernizing China's steel industry will require improving both energy efficiency and product quality, and the Chinese have an excellent opportunity to increase efficiency in this subsector.

\section{Industry subsectors: building materials}

The building materials industry includes manufacturing cement, brick, glass, lime, and other miscellaneous materials. This subsector consumed about $18 \%$ of industrial energy, providing $5 \%$ of total industrial gross output value [SSB, 1989c]. Most of this energy is used for cement and brick manufacturing, where obsolete and inefficient techniques are widely used. 
China is the world's largest producer of cement, manufacturing 203 million tons in 1988 , with current production growing rapidly due to a construction boom. Outdated techniques are used in this industry as well, and the plants are small. The number of plants was over 6000 , averaging 34 thousand tons per plant per year in 1988 [SSB, 1989c]. Vertical kilns (as opposed to modern rotating kilns) are used in small plants, which usually produce a lower quality output. Average energy intensity is about 0.16 tce/ton-clinker while the best could reach 0.10 tce/tonclinker [Liu, 1989]. In large and medium plants $^{3}$ (which produce $18 \%$ of total output), a wet process is prevalent, with an average energy intensity of 0.19 tce per ton-clinker, compared to an energy intensity of 0.12 tce per ton-clinker in Japan.

The electricity intensity of cement is lower in China because plants are not modernized. In 1985, overall electricity intensity of the industry was $104 \mathrm{kWh}$ per ton-clinker, compared to $143 \mathrm{kWh}$ per ton-clinker in the US. This is even lower in small plants, at 95 kWh per ton-clinker. However, with the introduction of newer plants, the electricity intensity of China's cement industry actually increased to $107 \mathrm{kWh}$ per ton-clinker in 1988 [Chinese data, SSB, 1989c; US data, Venkateswaran and Lowitt, 1988]. With the modernization of China's cement industry, electricity intensity is expected to continue to increase, while fuel intensity decreases.

There are large energy-savings potentials in the cement industry. At present, about half (by capacity) of vertical kilns are still operated manually. Mechanized vertical kilns have much better fuel efficiency, and also produce a higher quality product. According to experience in the Sixth FiveYear Plan (1981-1985), energy savings from this renovation is about $88 \mathrm{kgce}$ per ton of capacity renovated [Qin and Xin, 1989]. Our rough estimate of the energy-savings potential of this renovation at 1988 vertical-

${ }^{3}$ Large plants are those with an average annual output of greater than 600,000 tons, while medium plants produce between 200,000 and 600,000 tons. kiln cement production is about $8 \mathrm{Mtce}$, at an estimated cost of conserved energy of 330 yuan per tce. The best Chinese vertical kiln has a higher energy efficiency than even modern rotary kilns, but the quality of the output can be lower. In medium and large cement plants where the wet process is predominant, conservation measures are usually more difficult and costly, often requiring a complete overhaul in order to introduce the more advanced dry process and other new technologies.

Brick is the dominant wall material in Chinese buildings. Simple vertical kilns, the primary manufacturing technique $(85 \%$ of total output), are primitive and very energyintensive. Total energy used for brick production in 1985 was about $45 \mathrm{Mtce}$, half of the energy consumption in the buildingmaterial industry (Jiang, 1988). Because this is mostly a village-level industry, available information is still sparse. Because there promises to be a large potential for improved efficiency in this industry, further study is :..ommended.

Since building materials are in high demand, antiquated techniques are perpetuated to meet quantity requirements. Introducing large-scale modern manufacturing techniques and deveioping new generations of building materials will result in greater efficiency in the Chinese building materials industry.

\section{Industry subsectors: chemicals}

When energy used for feedstocks is included, the chemicals industry consumes about $18 \%$ of industrial energy use, but produces only $7 \%$ of industrial gross output value. The chemical industry is also very electricity-intensive. Of all industrial electricity, $18 \%$ (the largest subsectoral share in industry) is utilized for chemicals [SSB, 1989c].

The bulk of energy consumption (about $60 \%$ in 1986) in the chemical industry is for the production of nitrogen fertilizers. China is now the third largest producer of chemical fertilizer in the world, following the US and the USSR. Even so, demand exceeds production and imports are still required. In order to produce enough grain to feed its burgeoning population, a heavy input of 
chemical fertilizer is applied to crops. China makes $60 \%$ of its ammonia (the raw material used for nitrogen fertilizers) from coal and coke. This process requires more energy than petroleum- or natural gas-based processes because of coal gasification. The average energy intensity of ammonia production in 1985 in China was 2.1 tce per ton. This compares with a US intensity of 1.15 tce per ton [Daxiong et al., 1988].

A large share of nitrogen fertilizer production occurs in small plants, which use anthracites or coke as feedstock. In 1986, about $50 \%$ of China's total ammonia was produced by small fertilizer plants. There is a close correlation between the energy intensity of fertilizer production and the size of the manufacturing plant. This variation is largely due to feedstock differences. Economies of scale and the level of technology utilized are also important. Large plants (300 ktons or more annual capacity), which use either natural gas or naphtha as a feedstock, use 1.38 tce/ton; medium plants (40-150 ktons per year) use 2.23 tce / ton; and small plants (5-30 ktons) use 2.33 tce/ton. The difference in the electricity intensity of ammonia plants is extreme-11.8 $\mathrm{kWh} /$ ton for large, natural gas-based plants, and $1418 \mathrm{kWh} /$ ton for small coal-based plants [World Chemical Industry Yearbook: China Chemical Industry, 1988].

Renovation of small fertilizer plants plays a major role in energy conservation in chemical industry. In the Sixth Five-Year Plan (19811985 ) investment in energy savings reduced the overall energy intensity of small-plant ammonia production by $22 \%$ [Liu and Qin, 1989]. According to the Chinese authorities, the renovation measurements are very costeffective. Sales from the increased ammonia production resulting from renovation could more than pay for the retrofit. Our rough estimate of energy-saving potential at small ammonia plants based on 1986 production is about 10 Mtce.

Thirteen large petroleum or natural gas plants were imported in the 1970s. Petroleum-based ammonia production is more energy efficient than coal-based production. A shift away from the coal-based processes is therefore appealing for saving energy.
However, expansion strategies for fertilizer production are not driven solely by the criterion of energy efficiency. The nation's policy of energy independence constrains large projects based on petroleum inputs. At least in the near future, the government will emphasize production technology based on coal. For the longer term, the direction of fertilizer production processes will depend on the availability of domestic oil and gas reserves. Development of coal gasification technologies could also improve energy efficiency in this industry.

Plastics are also included in the energyintensive chemical industry. The demand for plastic products is increasing in China. The feedstocks for plastic production are also petrochemical, so this industry faces the same constraints as (and is in competition for inputs with) the rest of the chemicals industry. Ethylene, one of the main chemical inputs for the plastics industry, has been in short supply. Four 300,000 ton annual capacity ethylene plants were built in the 1980s. As a result, ethylene production has increased rapidly. Production almost doubled between 1985 and 1988, from 652 to 1231 thousand tons [Statistical Yearbook of China, 1989]. Because ethylene is a new industrial product for China, most manufacturing equipment was imported from Western countries as recently as the 1970 s and 1980 s. The physical product energy intensity is still higher (at 1.5 tce/ton in 1985) in China than in industrialized countries ( 1.1 tce/ton) [Zhou Fengqi, et al, 1989]. It is planned that in the Eighth Five-Year Plan (1991-1996) 200 million tons of ethylene production capacity will be built [People's Daily, Overseas Edition, 8/16/1991]. Energy conservation will have to come from importing modern production facilities.

\section{Industry subsectors: machine building}

The machine-building industry which covers a wide variety of subindustries (electronic equipment, machine tools, motor vehicles, to name a few categories), although significant, is not a heavy user of energy. Its energy intensity is even lower than that of the textile industry and has shown the largest decline of any sector in the 1980s. Machine 
building consumes $8 \%$ of industrial end-use energy but contributes $28 \%$ to total industrial gross output [SSB, 1989c].

The importance of the machine-building industry in energy consumption extends beyond this relatively small direct consumption, however, because its products become the major end users of energy, and thus directly and extensively influence the energy intensities of every other end use sector in the economy. Of total commercial end-use in China, $60 \%$ is either consumed directly by or via the products of this industry. According to a survey taken in the early $1980 \mathrm{~s}$, of the 20,000 products of this industry, only $5 \%$ had reached the level of technical sophistication of comparable technologies in the West in the 1970 s; $35 \%$ were 1960 s level technology and the remaining $60 \%$ were technologies from the 1950s and earlier [Zhang, 1984]. The Chinese machine-building industry is based on technologies introduced from the Soviet Union in the 1950s. Although some Western technologies were introduced in the following two decades, technical progress was slow before 198n. Outdated processes and technologies not only result in higher direct energy consumption, but also require higher inputs of other materials such as steel. For example, Chinese manufacturing machinery wastes about $40 \%$ of steel products input [Zhang, 1984]. Using more advanced technologies, Western countries can reduce this waste rate to closer to $10 \%$.

Some of the basic industrial equipment made by the machine-building industry is very inefficient compared with their modern counterparts. For example, the average heat efficiency of current industrial boilers is about $60 \%$, compared with $80 \%$ in western countries. Average efficiency of current thermal generation units is about $28 \%$, compared with near $35 \%$ in western countries. Fortunately, the Chinese government has moved into the direction of promoting product quality of the machine-building industry. Many regulations and standards targeting energy performance have been established in the last decade. A new generation of boilers, pumps, and motors, etc. has been developed. The machinebuilding industry should be a primary target for modernization and retrofit. It is a key sector for fundamental change in the energy efficiency of China's entire production economy.

\section{Industrial energy conservation programs}

The Chinese have taken significant steps in the last decade to modernize their modes of production, with a primary goal being to tap the large reservoir of cost-effective energy savings. Starting in 1981, the State Planning Commission, the State Economic Commission, and central banks offered preferential interest rates on loans for energy conservation investments. The government quickly carried out an extensive set of feasibility studies to identify worthwhile projects, classified as either technology modernization or capital construction projects. Ten billion yuan were allocated to these projects for the Sixth FiveYear Plan (1981-85).

The cost of conserved coal curve shown in Figure III.29 was generated from data on projects funded by the central government (information about locally funded projects is not available).

The estimated cost to produce coal rather than to save it was 400 yuan per ton for this period. Cost-effective savings were greater than 15 Mtce per year. Not only have these programs saved tens of millions of tons of coal, they also have saved money. Coal that would have cost 6 billion yuan was instead conserved at a cost of 3.5 billion yuan, for a net savings of 2.5 billion yuan and an average rate of return on investment of about $70 \%$. This program was continued through the Seventh Five-Year Plan, and although the data are not yet available, the savings are expected to be even larger.

The Chinese are aware that such savings potential exists, especially in industry. Capital constraints, rather than information, are keeping these savings from being quickly realized. 


\section{E. RESIDENTIAL AND COMMERCIAL}

Modern energy use in the residential and commercial sector ${ }^{4}$ was 185 Mtce in 1988, or $22 \%$ of the national total. The fuel structure changed slightly due to the rapid growth of electricity consumption in the 1980s. Figures III.30 and III.31 depict the energy use by fuel type in the residential sector and commercial buildings respectively. Again, the dominance of coal as an end-use fuel is evident.

Modern fuel consumption in the residential and commercial sector only reveals part of the story since rural households, which comprise about $80 \%$ of the population, meet their daily energy needs with biomass. When biomass is included, energy consumption in the residential and commercial sector constitutes about $45 \%$ of total final energy consumption.

An international comparison of per capita fuel consumption in the residential/ commercial sector is presented in Figure III.32. The disparity among countries is great.

The US per capita commercial/residential energy consumption is 9 times higher than that of China, and 26 times higher when Chinese biomass is excluded. Compared to India, China has both higher per capita modern energy consumption and higher per capita biomass consumption, due partly to winter heating requirements throughout much of China.

The largest subsectoral share of energy consumption in the residential and commercial sector is for household energy consumption. Of end-uses in the household sector, cooking and heating comprise virtually all of fuel (not electricity) consumption, $56 \%$ and $43 \%$ respectively in

4 Chinese statistics identify both a commercial sector and a "nonproductive" sector (i.e., work units which do not produce physical output, such as banks), the sum of which we here call commercial. Because of a definitional change, data for the residential subsector from 1984 and previous years is not directly comparable to data for 1985 and subsequent years.
1985 (including both rural and urban end-use) [Zhou, 1989]. Since commercial buildings have accounted for only about one-fifth of modern energy use in this sector throughout the 1980s, our focus is on residential end-uses. Furthermore, since biomass is primarily used for energy in rural areas, the patterns of rural and urban end-use differ widely. Our discussion will therefore consider rural and urban residential energy uses separately.

While urban residents generally have access to adequate supplies of energy, many if not most, rural residents suffer severe fuel shortages for at least part of the year. Forty percent have no access to electricity [Wang, 1988]. The problems and solutions in each setting are very different: in urban areas, reasonable strategies may include fuelswitching, investments in more efficient buildings and appliances, and demand management, while in rural regions, the most pressing need is for expansion of supply. In both cases environmental impacts are of great importance. In cities, the consequences of consuming energy are of most concern, while in the countryside, the effects of producing biofuels are important. Furthermore, data on rural end-use are very limited. For these reasons, the discussion of residential energy will be more detailed for urban end uses. 
Figure III.29: Cost of Conserved Energy, Sixth Five-Year Plan.

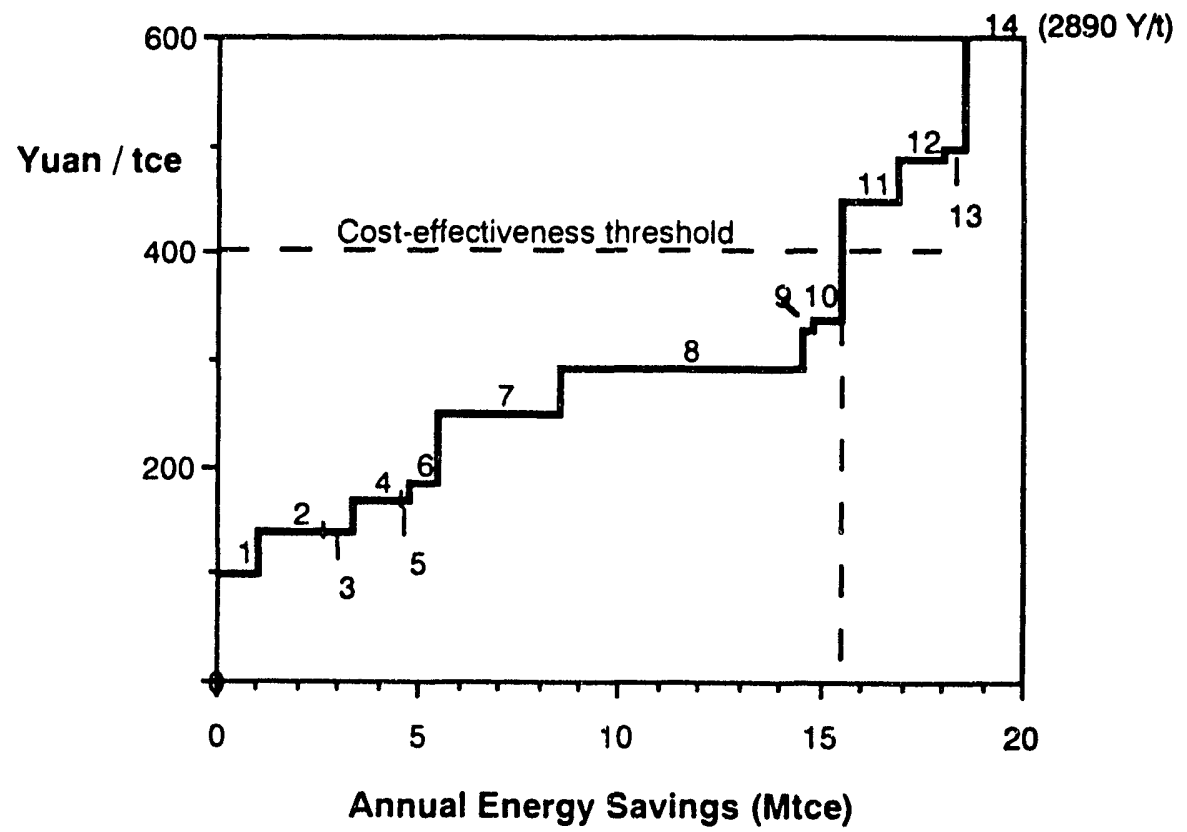

Source: Levine and Xueyi, 1990.

Notes: Project Descriptions -1) Efficient Domestic Coal Burning; 2) Renovation of Industrial Furnaces; 3) Use of Solid Coal Waste; 4) Processing Scrap; 5) Machines to Sift Coal; 6) Coal Washing; 7) Renovation of Industrial Boilers; 8) Waste Heat Utilization; 9) Renovation of Cement Kilns; 10) Miscellaneous New Technology; 11) Cogeneration; 12) Rehabilitation of Fertilizer Plants; 13) Closing Old Factories; 14) Continuous Casting.

Figure III.30: Energy Use in Commercial Buildings by Fuel, 1980-1988.

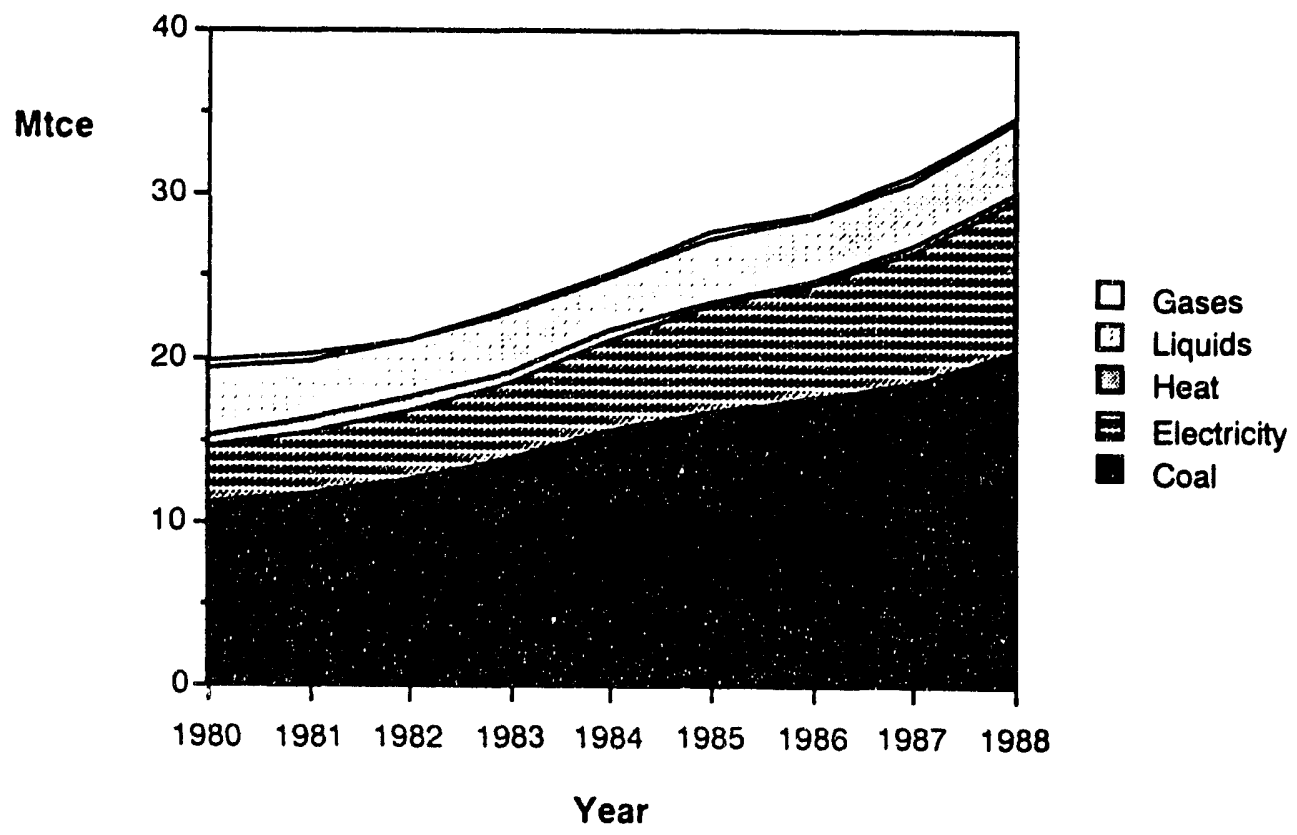

Source: Energy Statistical Yearbook of China, 1989 
Figure III.31: Residential End Use by Fuel, 1980-1988.

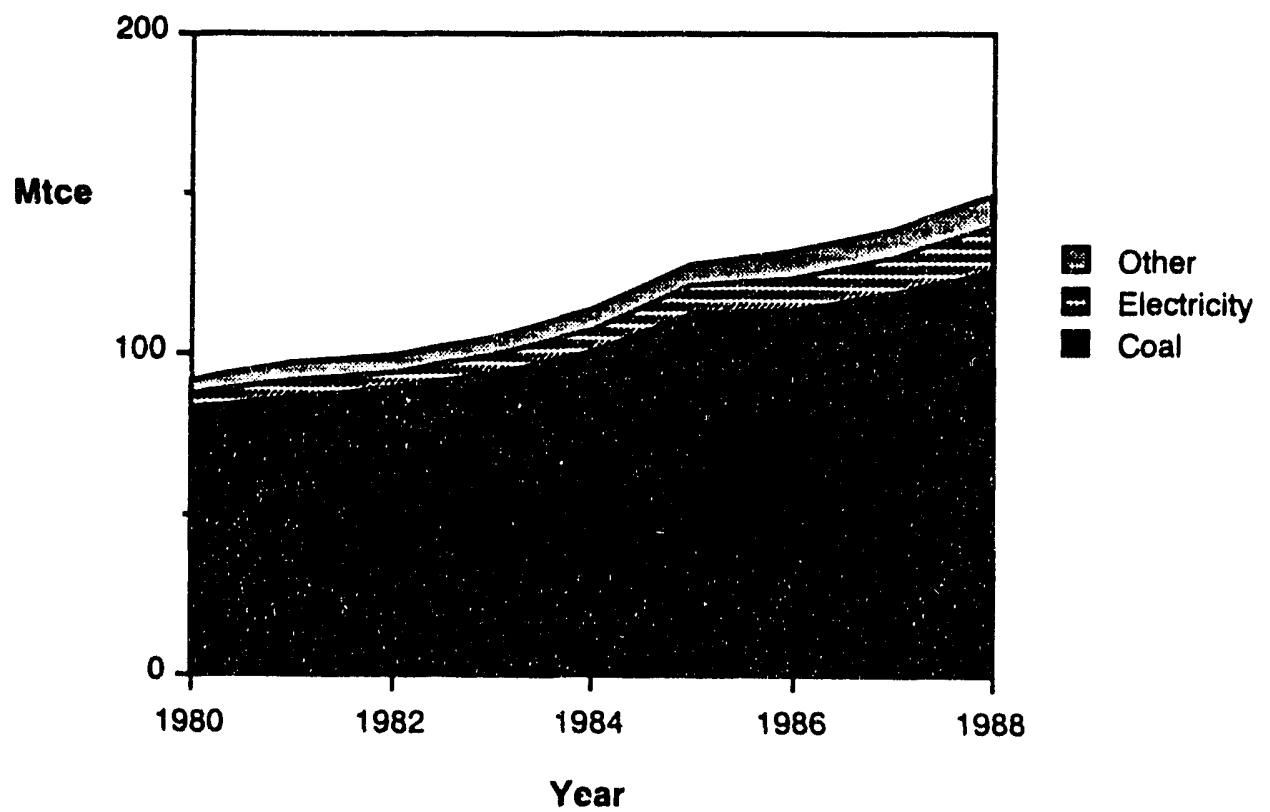

Source: Energy Statistical Yearbook of China, 1989.

Figure III.32: Per Capita Residential/Commercial End Use, Selected Countries, 1987.

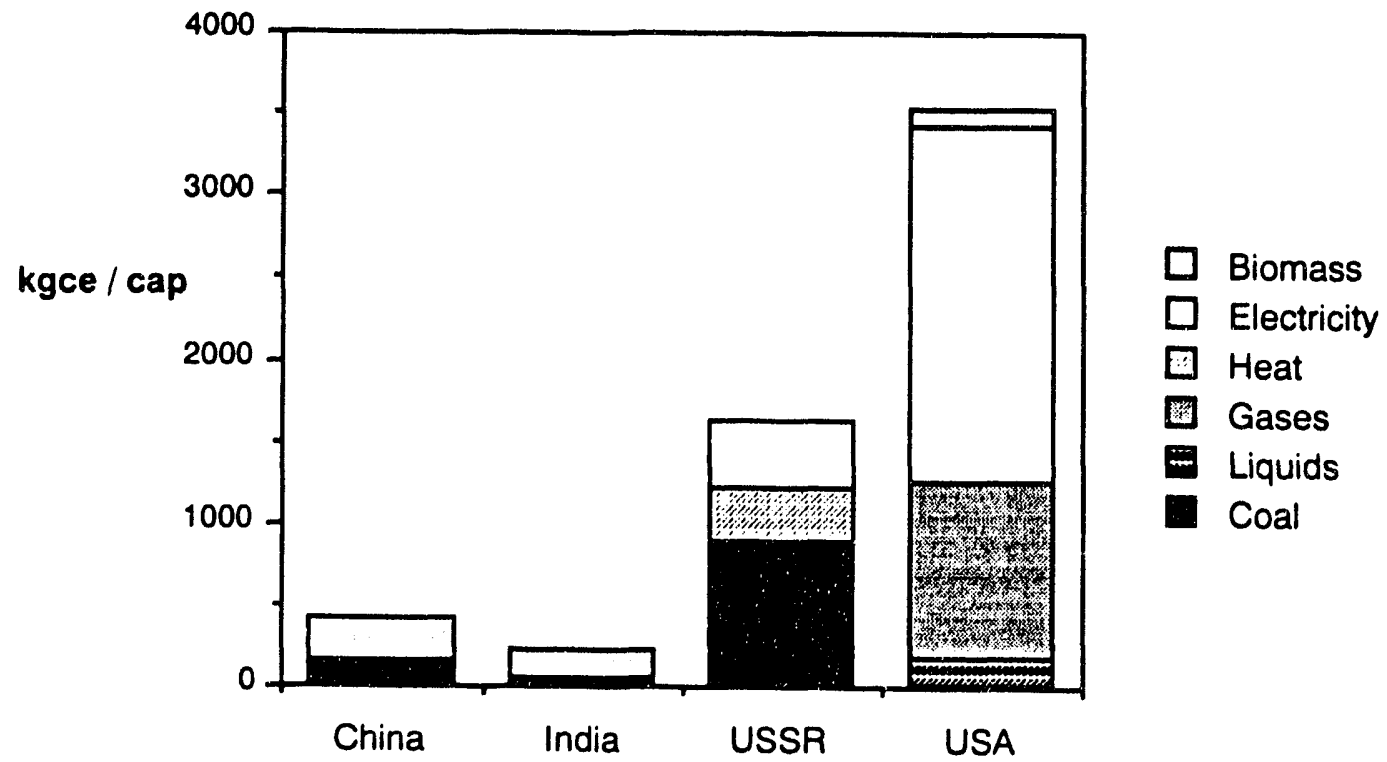

Sources: China - Statistical Yearbook of China, 1988; India - TERI Energy Data Directory and Yearbook, 1988; India - International Energy Studies Database, International Energy Studies Program, Lawrence Berkeley Laboratory; USA - International Energy Agency, 1988a. USSR - Energy Use and Conservation in the USSR, Schipper and Cooper, 1991. 


\section{Rural end-uses}

Although several surveys have been conducted, the State Statistical Bureau does not keep track of noncommercial energy consumption, which supplies most rural energy needs. The most recent Chinese data indicate that biomass consumption in 1987 was 266 Mtce, consisting of 133 Mtce (233 Mtons) of firewood, 130 Mtce (271 Mtons) of crop residues, and 3 Mitce (about 6 million dry tons) dung cake [National Rural Energy Planning, 1990].

The most recent survey of rural energy use shows that residential energy consumption accounted for about $66 \%$ of the rural total, as Figure III.33 illustrates. Of this $66 \%$, biomass provided $80 \%$, while coal provided most of the remainder.

The tradition of using biomass in China's rural areas has resulted in some very serious problems. From 1949 to 1980, China's forested areas lost 20 million hectares. The land area that is suffering water loss and soil erosion reached 150 million square kilometers, about $16 \%$ of the nation's total [Liang, 1988]. Since most crop residues are not returned to the fields, the humus content in cultivated soils keeps decreasing. Firewood consumption still exceeds by a factor of two the present sustainable firewood supply [Wang, 1988]. No substitutes are available for crop wastes used for cooking fuel.

The rural energy shortage and its consequences have received more government attention recently. During the last 15 years, four major campaigns have addressed the issues of small hydropower projects, household biogas digesters, efficient cookstoves, and firewood treeplanting. Of these projects, only the efficient cookstoves are targeted at end use, while the other programs are targeted at supply. The government launched the cookstove project in 1980 to help alleviate the rural cooking fuels shortage. From 1982 to 1987 , about $45 \%$ of rural households installed energy-saving stoves. The conversion efficiency of these stoves ranges from $20 \%$ to $30 \%$, compared with $10 \%$ or less for the older stoves. The estimated yearly energy savings of this program are about 20 Mtce [Liang].

\section{Figure III.33: Rural Energy Consumption by End Use and Fuel, 1987.}

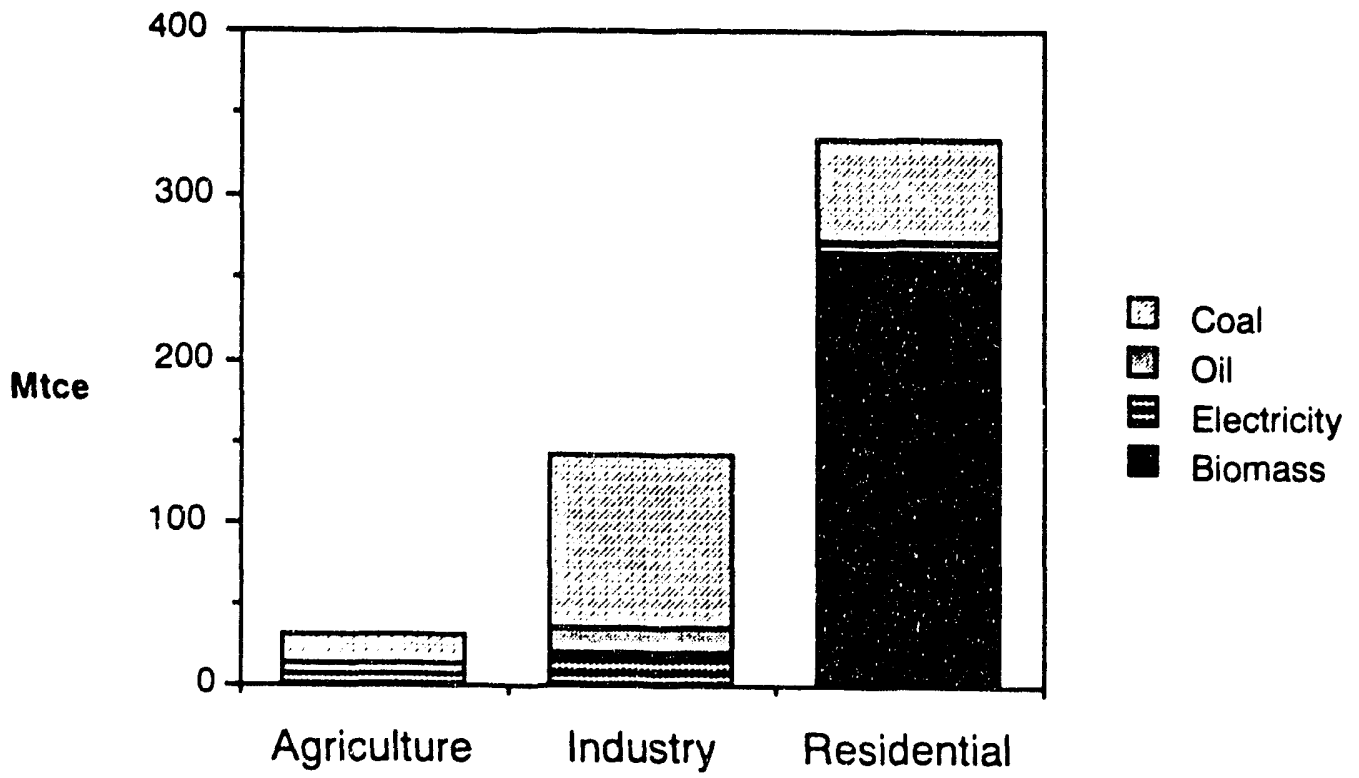

Source: National Rural Energy Planning, Standards Press, Beijing, 1990.

Source: Derived trom data from the 1988 Statistical Yearbook of China and the Energy Statistics Yearbook of China, 1986. 
According to the effectiveness of the stove program, we estimate that an additional 90 Mtce fuel could be saved at 1988 rural population levels. The efficiency improvements may not materialize entirely as energy savings. Instead, current low per capita energy use in rural households will increase, resulting in improved amenity levels. The effectiveness of this program iessens the burden on stressed rural ecosystems, and also has the benefit of improving indoor air quality.

\section{Urban end uses}

The most important energy end uses in urban households are cooking and heating, which depend mostly on coal. We estimate that cooking and heating energy accounted for about $90 \%$ of urban household energy consumption. 5 This figure varies by latitude and climate. In China, electricity is used almost exclusively in applications other than cooking and heating, mainly lighting and appliances.

Urban Cooking. Coal is the major fuel for urban household cooking. Most cooking coal is processed into briquettes, of either the ball or honeycomb type. In 1988, 33 Mtons of briquettes were sold in which 27 Mtons was honeycomb briquettes [Jiang, 1991]. In most urban households, a coal stove is kept burning all day for both cooking and for boiling drinking water because relighting is a nuisance. In the northern region, these stoves also serve for heating during the winter. These multipurpose devices create the largest cooking coal requirements of any country in the world and have become one of the largest sources of air pollution in Chinese cities. An average urban stove has a conversion efficiency of $15 \%-20 \%$, while dual-purpose (cooking and heating) stoves can have a

\footnotetext{
5 Urban household energy use was $9 \%$ electric tyin 1988 [SSB, 1989b]. Since electricity is almost never used for heating and cooking, while solid fuels and gas is used almost exclusively for this purpose, $90 \%$ is a reasonable estimate for the cooking and heating share of household energy use.
}

conversion efficiency of up to $40 \%-50 \%$ [Fengqi et al., 1989].

While coal is used for both cooking and space-heating, gaseous fuels are almost exclusively used for cooking. Urban households purchased an average of $236 \mathrm{~kg}$ of coal, or 0.168 tce/per capita in 1987, almost the same as seven years ago [SSB, 1988]. This usage varies widely between northern and southern cities. For example, citizens in Beijing consume about 0.26 tce of coal per capita per year, most of which may be used for heating ( $80 \%$ of the population had access to gases in 1987), while people living in Shanghai consume about 0.10 tce of coal per capita per year, most of which may be used for cooking (54\% of the population had access to gases in 1987) [SSB, 1988].

In recent years, gaseous fuels have become increasingly common in urban households, especially those in big cities. Among 441 cities $^{6}$ (with a combined urban population of about 140 million) surveyed in $1989,39 \%$ of the urban population had access to gaseous fuels, up from $22 \%$ (in 317 cities surveyed) in 1985. LPG is the most common of gaseous fuels, used by $57 \%$ of the gas-using population. Town gas is also important, used by $27 \%$ of the gas-using population [SSB, 1988]. The share of natural gas is $16 \%$. Only cities near oil or gas fields have access to natural gas [SSB, 1990]. Considering the higher capital cost of town gas capacity, LPG and natural gas would be the best choices of gaseous fuels, at least in the short-term. The future role of LPG and natural gas will depend on the development of the petroleum industry. Recent discoveries of oil deposits in Xinjiang and gas deposits in Shaanxi mean that gaseous fuels for residential use may be more widely available soon.

For most urban households, coal will continue to be the major cooking fuel. Although ownership of electric appliances by urban households rose throughout the 1980s, use of electric cooking appliances is limited by

6 The metropolitan areas surveyed also included some areas classified as rural. The percentages here refer only to urban residents. 
government-imposed electricity rationing. Survey data still shows rapid penetration of electric appliances in urban areas. A 1988 survey of 35 thousand urban households revealed that 30 electric cookers (mostly rice cookers) were owned per hundred households, up from almost nothing in the early 1980s. The city of Guangzhou has a rate of over 100 units per 100 households [SSB, 1989]. Increasing use of electric cookers is noteworthy because it could increase peak loads, and thus increase the difficulty of electricity-grid management. We expect urban cooking-coal consumption to decrease with the increasing number of gas-using households and the increasing use of electric cookers. The trend in rural areas may be the opposite because of the substitution of coal for biomass.

Urban Heating. Heating in China is fueled almost exclusively by coal. Piped hot water is almost nonexistent in China. Our discussion here will concentrate on space heating.

China is divided into three heating zones: the central-heating, the transition, and the non-heating zones. The central-heating zone is the area with more than 90 days with average daily temperatures below $5{ }^{\circ} \mathrm{C}$. In the transition zone, the number of such days is between 60 and 89 . Other areas belong to the non-heating zone. Buildings in the centralheating zone possess about $50 \%$ of the country's total urban building floorspace [Lang, 1988].

The government has imposed regulations on winter space heating that limit access to central-heating systems. Central heating in areas other than the central heating zone is illegal. Even with the restrictive government standard, the demand for winter space heating is high because of the large share of building floorspace in cold areas and poor building design with minimum envelope insulation. The average apartment building in the central heating zone consumes about 3 tce/per 100 square meters per year for space heating (this is coal consumed by boilers), two to three times higher than for new residences in the US with comparable climates [Huang and Rosenfeld, 1982].
The majority of buildings and households in the central heating zone use small, inefficient, and highly polluting boilers or stoves for heating. Data for 1985 show that within the central heating zone, only $5.7 \%$ of the residential building area is served by central-heating facilities, about $47.0 \%$ is served with small boilers, and $47.3 \%$ is heated by coal-burning stoves [Fengqi et al., 1989]. The conversion efficiency of these three types of heating modes are $75 \%, 55 \%$, and $30 \%-40 \%$ (at best) respectively. Because of the wide use of heating stoves, winter air pollution in northern cities is especially serious. Indoor $\mathrm{CO}$ pollution even poses lifethreatening danger to people, especially poorer families.

Installation of central-heating facilities has been encouraged by the government in recent years to conserve energy and control air pollution. Shenyang, the largest city in the northeast, built 3.36 million square meters of centrally heated floorspace and replaced 163 small boilers between 1981 and 1986 . This resulted in an annual savings of 62,000 tce of coal. In the immediate vicinity, ash content in the air decreased by two-thirds and carbon dioxide emissions decreased by $75 \%$ over the same period [Zhou, 1989]. Cogeneration power plants appear to be efficient in northern China because of both enduring cold weather and concentrated demand, but their high first cost limits the rate of construction of these plants.

Developing new window, new wall and roof materials and increasing initial capital input in building construction could reduce energy bills in the long run, while also providing a better urban environment. According to the Ministry of Construction, between 1985 and $2000,1.22$ billion square meters of new spaceheated residential building area will be built. Without any measures for energy savings, annual heating energy demand will exceed 50 million tce, three times as much as the 1985 level. According to some demonstration projects, a $5 \%$ increase of initial investment can save $30 \%$ of the heating energy demand [Lang, 1988]. From Huang and Rosenfeld's research, improving building insulation can pay for itself in avoided costs of coal supply alone. 
Considering additional savings from downsizing heating systems, long-term savings in energy use, decreased pollution, and avoided mining-related land destruction, society would benefit from more conservation in this sector. However, the artificially low price of coal for residential uses in many urban areas discourages the installation of the efficient amount of insulation.

Urban Lighting and Appliances. Electricity consumption has increased dramatically in the urban residential sector in recent years, primarily because of the rapid increase in the stock of household appliances. As shown in Figure III.34, from 1981 to 1988 ownership of television sets increased from 58 per 100 households (nearly all black-and-white) to 103 per 100 households (59 black-and-white and 44 color).

Refrigerator ownership increased from almost nothing to 28 per hundred households over the same period [SSB, 1989c]. The penetration of clothes washers also increased dramatically during this period. Increasing saturation of household appliances in urban areas drove growth of residential electricity consumption at an average annual rate of $16 \%$ between 1981 and 1988, from 11.8 billion $\mathrm{kWh}$ to about 34.3 billion $\mathrm{kWh}$ [SSB, 1989b]. In 1985, lighting accounted for about $30 \%$ of urban household electricity consumption, while appliances accounted for about $70 \%$ [Zhou, 1989]. The share of appliance end use is expected to increase, mainly due to the increase in refrigerator ownership.

Because of shortages, residential electricity use has come under strict control in recent years. Many state-owned work units are required to install electricity meters in their employees' apartments (most Chinese work units provide housing for their employees). Metering of electricity has reached most urban households. The electricity bill of a typical household is large relative to its income, generally larger than rent (average residential electricity price in 1988 was 0.19 yuan $/ \mathrm{kWh}$ and the average rental price was $0.18 / \mathrm{m}^{2}$ ) [SPB, 1989]. Households therefore have a strong incentive to save electricity. Fluorescent lamps, popular in cities, and low wattage incandescents $(25-40 \mathrm{~W})$ are used for lighting.

Figure III.34: Possession of Appliances in Urban Households.

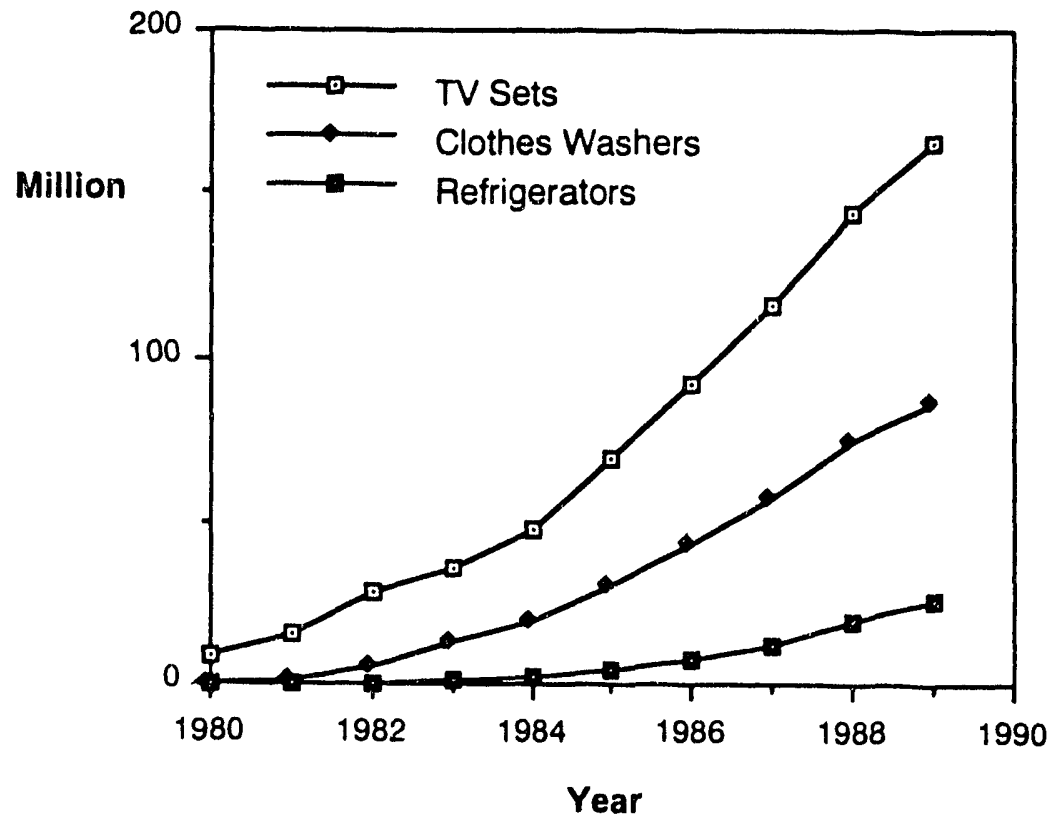

Source: Statistical Yearbook of China, 1989. 
Household refrigerators used in China range in volume from 150 liters to 250 liters, with those under 200 liters being more affordable and popular. Refrigeration accounts for a large share of already high electricity bills, so it is not uncommon for households to run their refrigerators only part time during the winter.

From the viewpoint of developed nations, urban electricity consumption in Chinese residences is still extremely low, about 350 kWh per urban household in 1988, compared with about $10,000 \mathrm{kWh}$ per household in the US. In order to continue improving living standards without exacerbating existing shortages, the energy efficiency of new appliances needs to be increased.

Although urban residents consume much less energy than people in western countries, there still exists large potential for energy conservation because of inefficient end uses. Promoting honeycomb briquettes in recent years has proved to be a cost-effective way of saving coal and reducing air pollution. Burning honeycomb briquettes can save $30 \%$ and $20 \%$ of the coal used in burning raw coal and ball briquettes [Fuel distribution in China, 1988]. In practical use, the savings rate may be lower. Our estimate of coal savings from diffusing honeycomb briquettes is about $4 \mathrm{Mtce} /$ year at 1988 urban household cooking coal consumption. Space heating is another major area for coal conservation. Replacing dispersed small boilers and heating stoves would not only save $20 \%-35 \%$ coal consumption, but also would improve air quality and the quality of heat supply. Chinese refrigerators on the average consume about $1 \mathrm{kWh} /$ day of electricity, or 365 $\mathrm{kWh} /$ year. Introducing new technology could reduce this usage substantially. According to Meyers, a popular new 2-door-200-liter Korean refrigerator in 1987 only consumes 240 $\mathrm{kWh} /$ year of electricity. Electricity savings in lighting are also promising, since China now has the ability to manufacture highperformance electronic ballasts and compact fluorescent lamps. Since in the long-run, residential energy consumption will increase absolutely, government policy towards energy conservation in the residential sector should create incentives to diffuse efficient end use technologies rather than just restrict consumption.

\section{G. TRANSPORTATION}

Transportation consumed about 64 Mtce of energy in 1988 and accounted for $8 \%$ of total energy consumption in China. ${ }^{6}$ In comparison to developed countries, this relatively small share of transportation energy use indicates less mobility and less per capita freight

6 Chinese accounting procedures understate energy end use in transportation. About $70 \%$ of gasoline consumption is not reported as transportation energy use. Most automobiles in China are operated by non-transportation enterprises, so their fuel consumption is reported as end use in other sectors. About two-thirds of all road trips are reported in this manner [World Bank, 1985]. Also, tractors play an important role in rural transportation. Furthermore, the State Statistical Bureau of China reports energy use in transportation, postal services and telecommunications together in the same category.

In order to better estimate China's transportation energy use, we made the following adjustments to compensate for these data problems. First, we assumed that the energy used in postal services and telecommunications was negligible and can be ignored. The transportation sector consumption of diesel oil includes reported transportation use plus $20 \%$ of agricultural use and $10 \%$ of industrial use. Data in the Statistical Yearbook of China indicates that trucks and transportation tractors accounted for $20 \%$ to $30 \%$ of agricultural sector machine power in the 1980s. For the time period we are concerned with, we believe that taking $20 \%$ of reported agricultural diesel use as transportation sector use is a reasonable adjustment. We estimate that $10 \%$ of the national truck fleet (with payload over 4 tons) is diesel fueled, and $90 \%$ of the diesel truck fleet is owned by industrial work units (Chinese statistics show that less than $10 \%$ of the national truck fleet is owned by transportation companies). Using an average diesel use per vehicle-km of 35 liters $/ 100$ vehicle-km (from ESYC 1989, probably for 8-ton trucks, the most common size of deisel truck in China) and an estimated average vehicle travel of $10,000 \mathrm{~km} /$ year, we estimate that $10 \%$ of reported industrial diesel use was for transportation in 1988. This percentage was applied to $1980-1987$ data as well. 
movement. Figures III.35 and III.36 compare freight and passenger traffic structures for the four comparison countries. The freight traffic data for India are for 1985, but are incomplete (they include only rail and road freight volume, and waterborne freight does not include ocean-going traffic). The passenger traffic data for India are for 1985 and include only rail and road passenger traffic and hence, are also incomplete.

When the per capita figures are calculated, the discrepancies between the developed and developing countries are magnified. But we must consider the geography when making this comparison (for example, the average trip length in the Soviet Union is longer than in China). Were it not for pipeline transport, China's transport shares would be very similar to those of the USSR, while the US has a much larger share of road transport. China also currently has very little road transport of passengers.

Per capita road travel in China was a very low $230 \mathrm{~km}$ in 1988, 65 times lower than that of the US at $15,000 \mathrm{~km}$ per capita. Rail travel, however, is more widely utilized in China. The fuel composition of transportation energy is illustrated in Figure III.37.

The use of coal as a transportation fuel has been declining as the result of railway electrification and increasing use of diesel engines. The rapid growth of gasoline consumption, $7 \%$ per annum since the early 1980 s and $10 \%$ in the most recent three years, corresponds with the rapid growth in highway transportation. Diesel consumption has grown even more rapidly, at $14 \%$ per annum since 1985 . Fuel substitution in railway transportation and the growing diesel truck fleet are the major contributors to this trend.

The transportation fuel structures of selected countries are compared in Figure III.38. The US transportation sector represents an extreme that almost entirely relies on oil. We expect that in the future, China's transportation fuel structure will be closer to that of the USSR, with an emphasis on railway electrification and an expansion in road transportation.

Figure III.35: Per Capita Freight Traffic, Selected Countries, 1987.

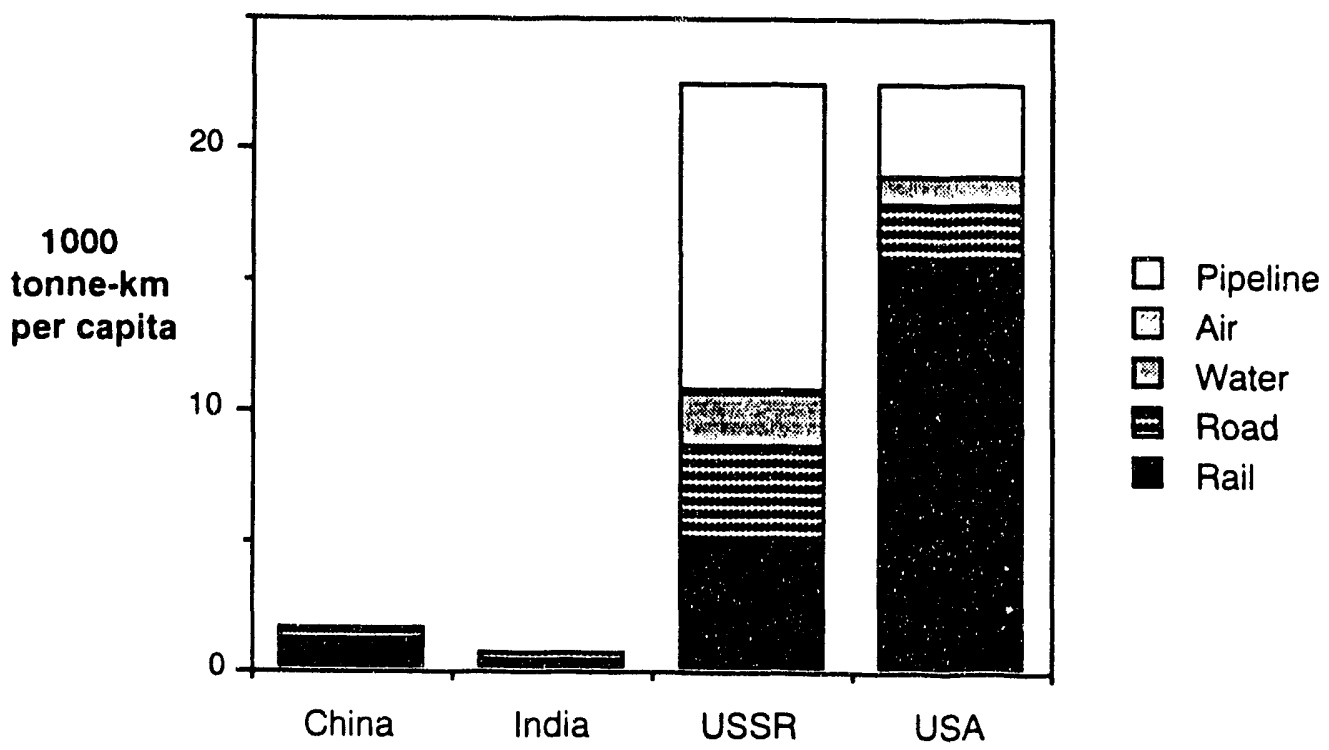

Sources: China - Statistical Yearbook of China, 1988; India - TERI Energy Data Directory and Yearbook, 1988; USSR - Energy Use and Conservation in the USSR, Schipper and Cooper; USA - Statistical Abstract of the United States, 1989. 
Figure III.36: Per Capita Passenger Traffic, Selected Countries, 1987.

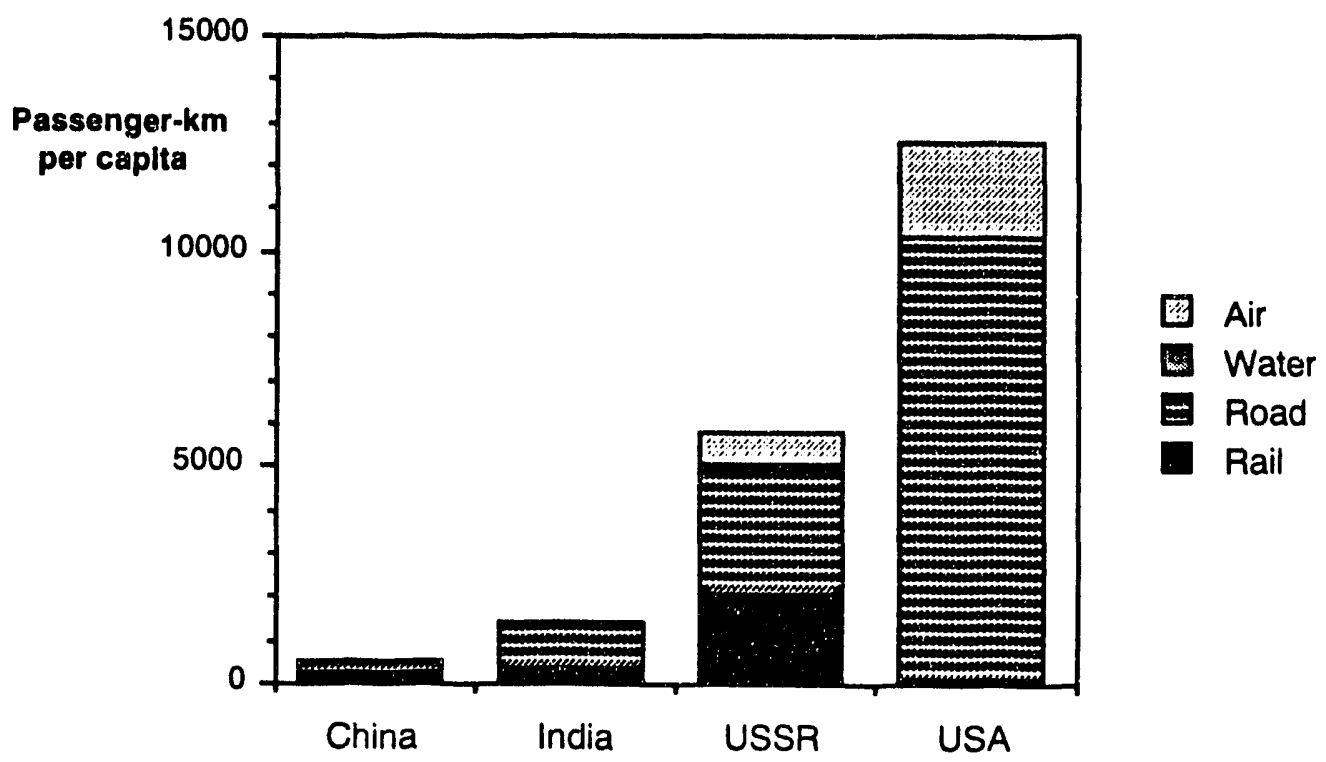

Sources: China - Statistical Yearbook of China, 1988; India - TERI Energy Data Directory and Yearbook, 1988; USSR - Energy Use and Conservation in the USSR, Schipper and Cooper; USA - Statistical Abstract of the United States, 1989.

Figure III.37: Transport Energy Consumption by Fuel, 1980-1988.

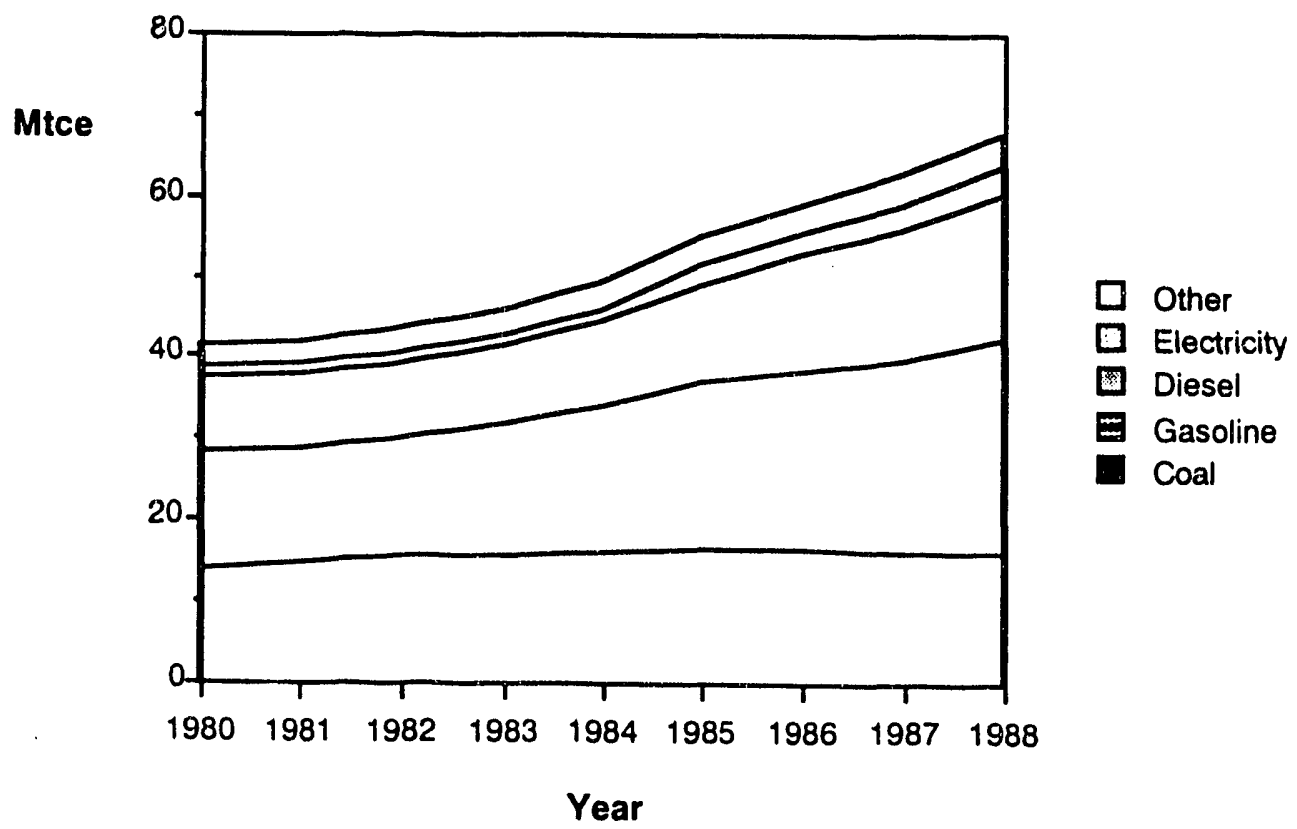

Sources: China - Statistical Yearbook of China, 1989.

Notes: Gasoline is total national use. Diesel is reported transportation use $+20 \%$ of agricultural diesel use + $10 \%$ of industrial diesel use. Other fuels are kerosene, crude oil, fuel oil, and natural gas. Energy use in postal and telecommunication services is reported within the transportation category and is not separated here. 
Transportation energy end use share by mode is given in Figure III.39. Continued rapid growth in highway transportation is likely to reverse the pattern of railway fuel dominance in the near future.

Historical data of freight and passenger traffics are plotted in Figures III.40 and III.41. The growth in bo'th categories was dramatic in the 1980 s as the economic reforms unfolded. Personal mobility increased from 176 to 583 person-kilometers per year between 1980 and 1988. Freight movements more than doubled during the same period. Highway and railway densities also increased, although they have not yet reached $20 \%$ of US levels [Yearbook of the World Economy, 1988]. Railway transportation, although declining in importance, still dominates domestic transportation, composing 53\% of passenger traffic volume (passenger- $\mathrm{km}$ ) and $59 \%$ of inland freight traffic volume (ton $-\mathrm{km}$ ) in 1988. Looking to the future we expect that rail will continue to play a major role in freight transportation, and that highways will become the major force in passenger transportation.

The following discussion will examine the major transportation modes in some detail with emphasis on their energy consumption and efficiency.

\section{Railways}

Rail is the most important mode of transport in China. In 1988, 53\% of passenger traffic (passenger-km) and $41 \%$ of freight traffic $($ ton $-\mathrm{km}$ ) were moved by railway. For the past 40 years, China has endeavored to build up this national railway network. Railway construction has been the major task of transportation development. Unfortunately, The Chinese have chosen to emphasize increasing length, with less importance placed on quality and upgrading the locomotive fleet, which has left China's railway system very outdated.

As of 1988, the locomotive stock consisted of $54 \%$ steam, $37 \%$ diesel, and 9\% electric locomotives [Statistical Yearbook of China, 1989]. Coal is still the dominant fuel in railway transportation due to the large number of steam engines. In 1985, coal counted for $81 \%$ of railway energy use, while diesel provided $13 \%$ and electricity the remaining $6 \%$ [Yang, 1988]. The average fuel intensities for steam, diesel, and electric locomotives are currently about $11.4 \mathrm{kgce}$ per thousand ton$\mathrm{km}, 2.5 \mathrm{~kg}$ diesel per thousand ton- $\mathrm{km}$, and $11.3 \mathrm{kWh}$ per thousand ton- $\mathrm{km}$ respectively (these are gross ton- $\mathrm{km}$ ). In coal equivalent units, the fuel intensities are 11.4 kgce per thousand ton-km for steam locomotives, 3.6 kgce per thousand ton-km for diesel locomotives, and $4.6 \mathrm{kgce}$ per thousand ton$\mathrm{km}$ for electric locomotives [ESYC, 1989].

The inefficiency of the steam engines is obvious, although these engines burn the fuel that is most abundant domestically. Replacing them with electric engines would still allow the utilization of China's rich coal reserves. Even when we consider transmission and distribution losses, electric locomotives have a much higher efficiency than steam. In addition, emissions control is much easier at a single electric plant than on many locomotives. Because China has scarce oil resources, the government has chosen electricity as the major power source for future railway transportation. Electrification has been the main focus of railway construction in recent years.

For passenger transport by rail, China has a lower energy intensity per passenger $-\mathrm{km}$ than might be expected because seat occupancy generally exceeds $100 \%$ year round. Lower train speeds also reduce fuel requirements. Because of smaller engines and poor railway maintenance, the average train speed is much lower (by a factor of two or three) than in Western countries. It is therefore expected that electrification of the rail system will not decrease energy intensity as much as the efficiency gain suggests, as speed, and possibly comfort, will increase. 
Figure III.38: Fuel Use in Transportation, Selected Countries, 1987.

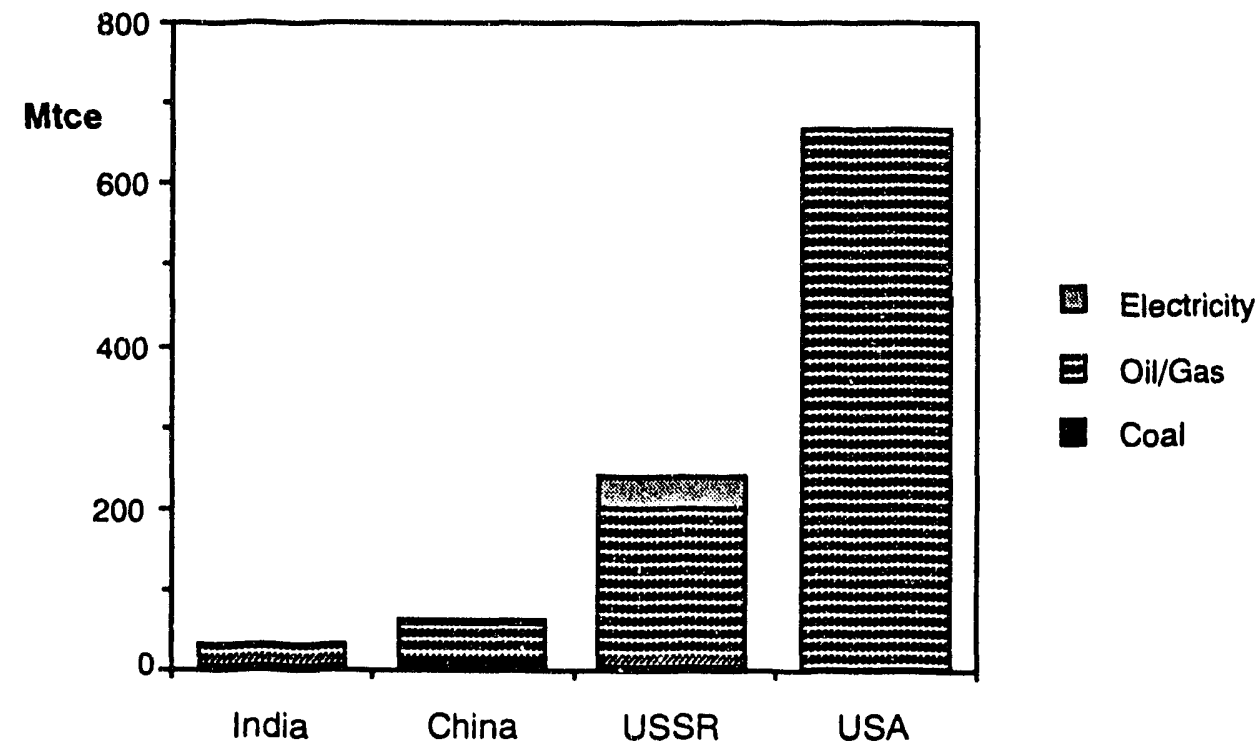

Sources: China - Energy Statistics Yearbook of China, 1989; India - International Energy Studies database, Energy Analysis Program, Lawrence Berkeley Laboratory, 1990; USSR - Energy Use and Conservation in the USSR, Schipper and Cooper; USA - IEA, Energy Balances of OECD Countries, 1987-1988, 1990.

Notes: Only the USSR has considerable natural gas use in the transportation sector.

Figure III.39: Transportation Energy End-Use Shares by Mode, 1985.

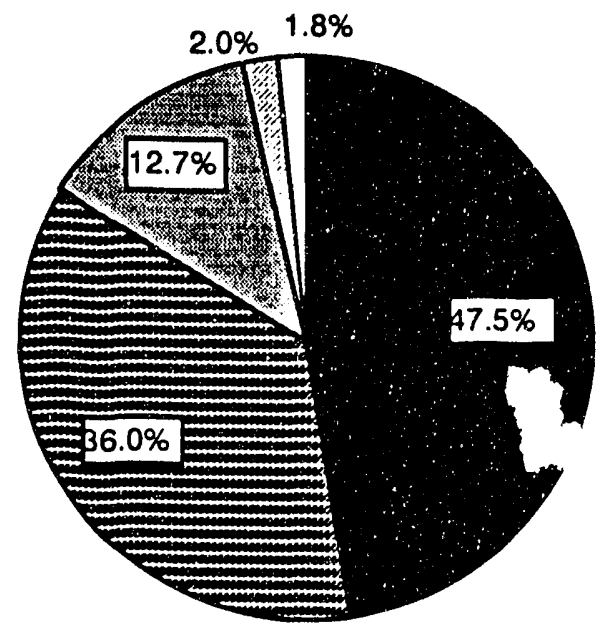

Sources: Yang, 1988. 
Figure III.40: Passinges Travel by Mode, 1950-1988.

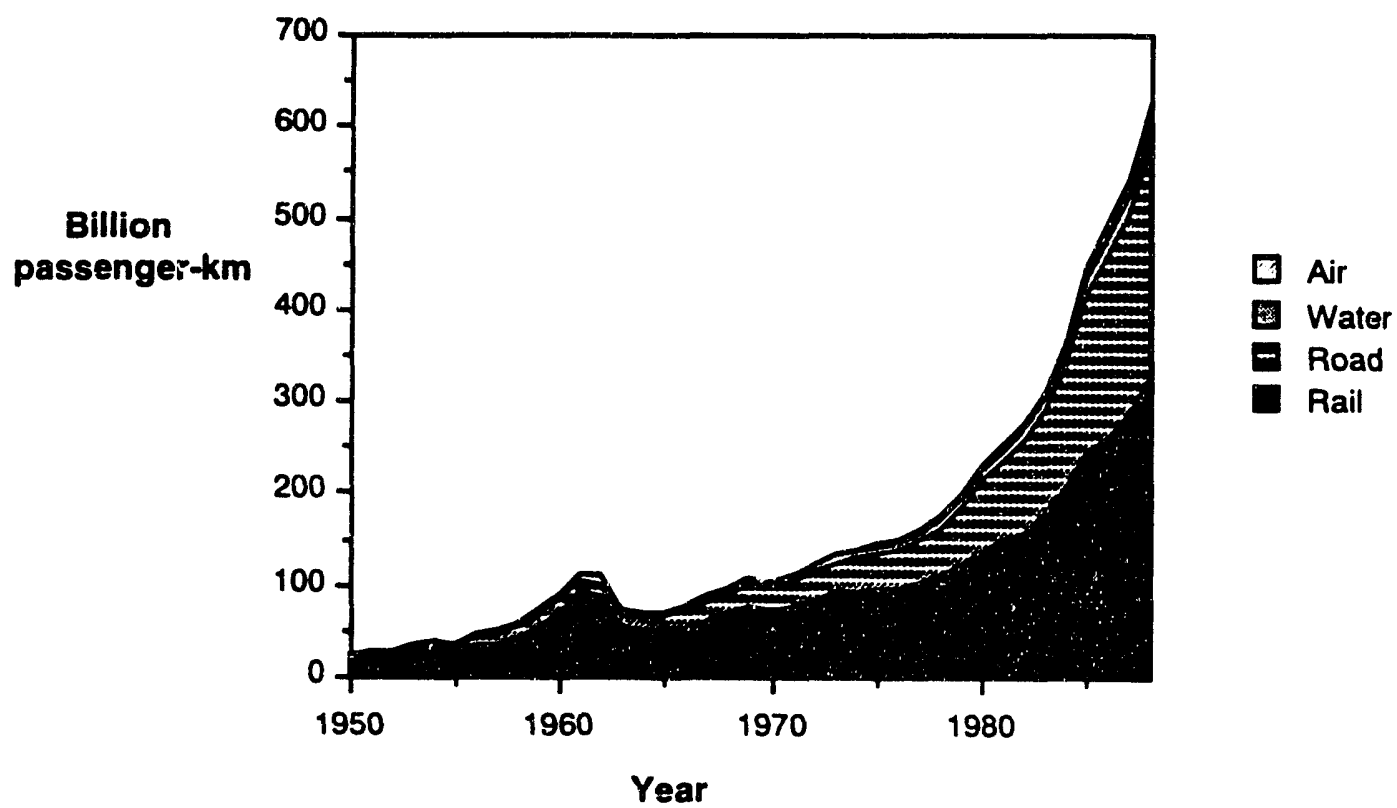

Sources: Statistical Yearbook of China, 1989.

Figure III.41: Freight Movements by Mode, 1950-1988.

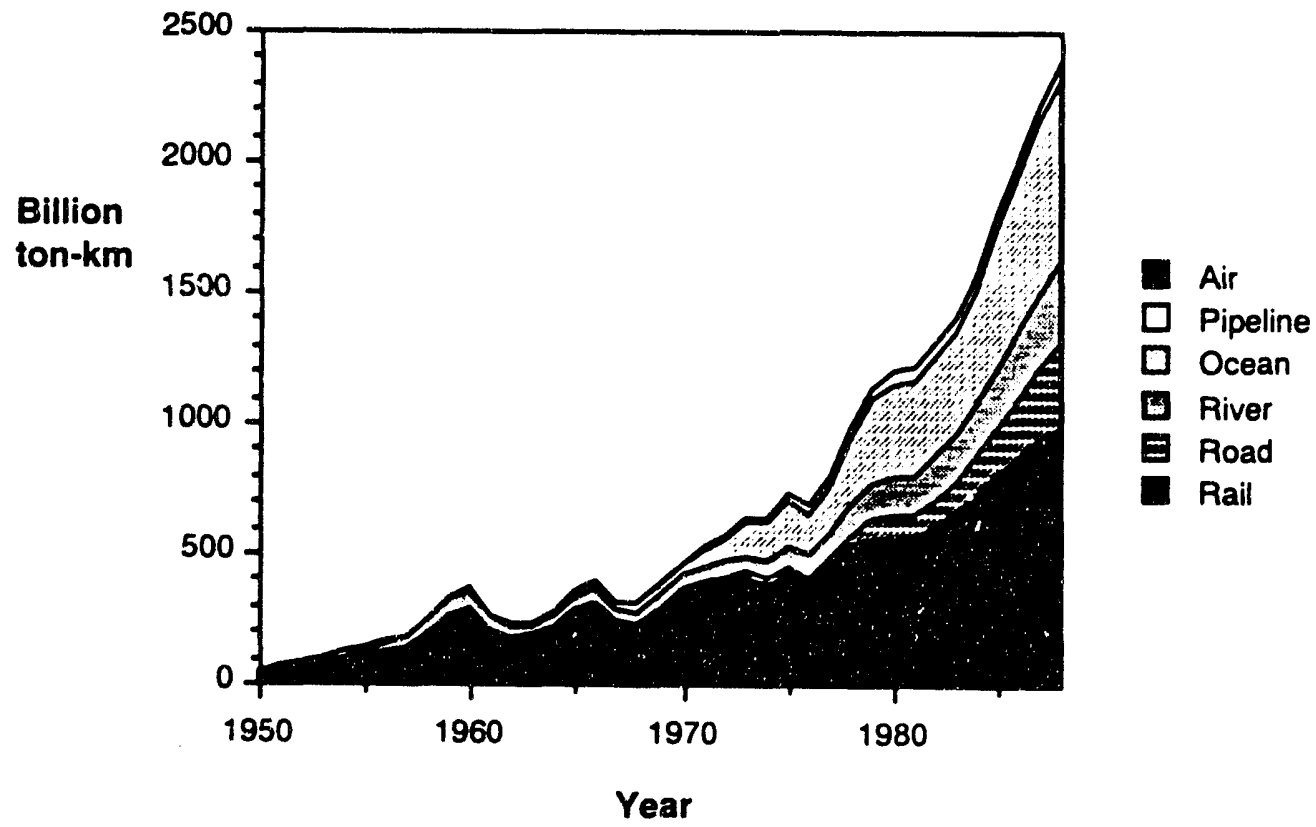

Sources: Statistical Yearbook of China, 1989.

Notes: The coverage of the road freight data is different before and after 1979 . 


\section{Highways}

Construction emphasis has shifted from rail to roads in recent years. Highways were the fastest growing transport mode in China in the 1980s. During this decade there was a large increase in vehicle stocks, which were in part responsible for the large increase in road traffic. In 1979, there were only 100,000 passenger vehicles, 1.6 million trucks, and almost no motorcycles in China. As of 1988, China's road transportation fleet included about 1.3 million passenger vehicles (299 thousand buses and 1.0 million minivans and cars), 3.1 million trucks (2.4 million large trucks-average payload of 5 tons, and 719 thousand small trucks-average payload of 1.7 tons), 0.2 million specialty vehicles, 3.0 million motorcycles (mostly under $80 \mathrm{cc}$ ), and 3.9 million transportation tractors (mostly small-horsepower tractors, e.g. $12 \mathrm{hp}$ ) [Statistical Yearbook of China, 1989]. These trends are expected to continue, and to increase demand for liquid fuels in the future.

Highways play an important role in passenger transportation. In 1988, $41 \%$ of passenger traffic was carried by highways or urban routes, compared with highway freight-traffic share of $19 \%$. Even so, the Chinese highway network is still poorly developed. India's per capita road passenger traffic is about five times higher than China's. Highways need to play a larger role in passenger transportation because using railway capacity to transport people is not as economic as to transport freight. China's railway system is currently heavily burdened by passenger travel.

Highway freight transportation in China is inefficient for several reasons: the majority of trucks have gasoline rather than diesel engines; transport in non-transportation enterprises is poorly coordinated; and roads are in poor condition.

About $77 \%$ of trucks in China are so-called large trucks, with a standard payload of four or five tons, and are fueled with gasoline. The fuel economy of the newest Chinese gasoline truck at this payload is 25-26.5 liters per hundred $\mathrm{km}$, or about 17 ton-km per liter. The most popular diesel model in
China has a payload of eight tons. The fuel economy of this model is $\mathbf{2 4}$ liters per hundred $\mathrm{km}$, or 33 ton-km per liter, almost twice as high as gasoline trucks [Yearbook of China's Transportation, 1987]. Actual fuel intensity of the Transportation Ministry's trucking companies, which includes partial payloads, is 72 liters per thousand ton-km for gasoline trucks and 49 liters per thousand ton-km for diesel trucks [Energy Statistical Yearbook of China, 1989].

Tractors are widely used for transport in rural areas. This use competes with agriculture for diesel fuel and exacerbates rural diesel shortages. This large pool of transportation tractors could be replaced with more fuel efficient light trucks.

There are also misincentives in nontransportation enterprises that result in inefficient transport use. The majority of registered vehicles are so-called own-account vehicles owned by nontransport organizations. The load factor in the ownaccount trucking sector, which accounts for about two-thirds of total ton-km, is nnly $30 \%$, compared with more than $60 \%$ for trucks operated by the state transport departments [World Bank, 1985]. Improving the capability and flexibility of the professional trucking system could help to improve overall road transport efficiency.

Poor road conditions in China also reduce the energy efficiency of highway transportation. As of 1986, China's 963.2 thousand km highways were divided as shown in Table III.5.

More than $80 \%$ of China's highways were in poor or very poor condition. Highways are generally narrow and crowded. The weighted average highway speed from Table 5 is $\mathbf{3 0}$ kilometers per hour.

Finally, low quaility gasoline used in China also reduces fuel efficiency.

Extrapolating current trends, we expect the importance of highway transportation to continue to increase. China's automotive industry has highlighted two majur areas for development: heavy trucks and passenger 
Table III.5: Class Distribution of China's Highways.

\begin{tabular}{cccc} 
Class & $\begin{array}{c}\text { Width } \\
(\mathrm{m})\end{array}$ & $\begin{array}{c}\text { Design Speed } \\
(\mathrm{kph})\end{array}$ & $\begin{array}{c}\text { Distance } \\
\text { (thousand } \mathrm{km} \text { ) }\end{array}$ \\
\hline 1 & 15 & $80-100$ & 0.8 \\
2 & 9 & $40-80$ & 23.7 \\
3 & 7 & $30-60$ & 136.8 \\
4 & 3.5 & $20-40$ & 476.8 \\
5 & 3 & $(20)$ & 325.1
\end{tabular}

Source: Li Jinwen, et al., Handbook of China's Transportation, Economic Science Press, Beijing. 1989.

cars. Currently, several long-distance, highquality highways are under construction.

Connecting major cities with superhighways is a high priority of China's planners and is being enthusiastically encouraged by international lending institutions. With the promotion of road transportation, an increase in oil demand is expected. Liquid fuel shortages, which have already been a serious problem, may become even worse if supply and prices cannot be properly managed.

\section{Other modes}

Freight volume on inland waterways in 1988 was $18 \%$ of the total, second only to railway freight volume [Statistical Yearbook of China, 1989]. Compared with European countries with developed river transportation systems, China's inland river courses are still underutilized. Since shipping is the least energy-intensive mode of transport, increasing its share of overall freight volume will decrease the energy intensity of freight transport. Because developing waterways is less capitalintensive than other transportation works, China's extensive inland waterways will be an investment priority.

Air transportation is used only for passenger travel; airway freight volume is negligible. This modern form of conveyance is still an inaccessible luxury to the vast majority of Chinese people. Passenger travel by air comprises about $3 \%$ of total passenger-miles.

China's commercial airplane fleet is a mix of Soviet, Western European, American, and domestic models, some of which are quite old. Boeing 707s and their equivalents are most prevalent, although newer models such as Boeing 737, Boeing 767, and MD-82 have been introduced more recently. Average fuel economy for the Chinese airfleet was $1.16 \mathrm{~kg}$ fuel per ton- $\mathrm{km}$ in 1970, improving to $0.50 \mathrm{~kg}$ per ton-km in 1987 [SSB, 1989a]. This improvement is substantial and is largely due to the introduction of new planes.

Pipeline transport capacity has increased in tandem with the petroleum industry. As of 1987, China had $6416 \mathrm{~km}$ of crude oil pipeline, $6239 \mathrm{~km}$ of natural gas pipeline, and $1108 \mathrm{~km}$ of oil product pipeline. Total transport by pipeline was 62.5 billion ton$\mathrm{km},{ }^{7}$ consisting of $97.7 \%$ crude oil, $2.2 \%$ natural gas, and $0.1 \%$ of oil products. Presently, pipeline capacity for refined oilproducts is in short supply while crude pipelines are underutilized. Most bulky oilproduct transportation has to be handled by railway. In 1975, the energy intensity of pipeline operation was $23.5 \mathrm{kWh}$ per thousand ton-km of electricity and $11.84 \mathrm{~kg}$ per thousand ton $-\mathrm{km}$ of fuel oil. In 1987, the respective intensities became $30.2 \mathrm{kWh}$ per thousand $t o n-\mathrm{km}$ and $6.64 \mathrm{~kg}$ per thousand ton- $\mathrm{km}$, indicating a trend of substituting electricity for fuel oil in pipeline energy use [SSB, 1989a]. Construction of new pipelines will be necessary if the oil reserves in the far west region of the country are developed.

Although still relatively undeveloped, the transport sector is growing along with the rest of the Chinese economy. Rail will continue to play a major role, though this mode will be

7 It is assumed that 1000 cubic meter-kilometers of natural gas is equivalent to 1 ton-kilometer of oil. 
displaced more and more by highways. Fuel use in railway transport will shift to electricity. Because the use of road vehicles will increase, an increase in demand for liquid fuels is expected. These changes will challenge the Chinese petroleum industry, which, as we have seen, is already short of supply capacity. Shortages emphasize the importance of identifying and capturing conservation opportunities in the transport sector.

\section{H. AGRICULTURE}

The agricultural sector includes farming, fishing, animal husbandry, forestry (not including lumber), and water management. In 1988 , agriculture contributed $27 \%$ of the total gross domestic product, making it the second largest economic sector in China [SSB, 1989c]. However, due to the fact that Chinese agriculture continues to be very labor intensive, direct agricultural consumption of commercial energy remains small

One unique characteristic of Chinese fuel use in agriculture is (not surprisingly) the large share of coal usage. Agricultural energy use in developed countries is much more intensive of liquid fuels and electricity.

Energy use in agriculture was 42 Mtce in 1988, comprising about $5 \%$ of the total commercial energy consumption in China [SSB, 1989b]. ${ }^{8}$ Coal, electricity and diesel fuel are the main energy sources for agricultural production, as is evident in Figure III.42.

The contributions of these fuels to toial agricultural energy end use in 1988 were $42 \%$, $37 \%$ and $21 \%$ respectively, or $17.5,15.3$, and 8.9 Mtce. Coal consumption in agriculture has increased recently. Coal is used mainly for drying agricultural products like grain, tea, and tobacco. Preparing feed for hogs, which are one of the main products of Chinese agriculture, may also contribute to the large demand for coal in this sector [Zheng, 1988]. In the last 10 years, about $40 \%$ of agricultural

\footnotetext{
8 Again, we adjusted end-use data to correct for transport diesel use that was being counted in the agriculture sector. The use of agricultural tractors for transportation is common in rural China.
}

electricity was used for irrigation. About $30 \%$ of adjusted agricultural diesel use, or 2.9 Mtce, is used for irrigation [Zheng, 1988] (see Figure III.43). The category "Other" includes a small amount of crude oil, fuel oil, and kerosene. Diesel use is adjusted $(-20 \%)$ to account for transportation use of tractors.

About $30 \%$ of the nation's total diesel supply is distributed to rural areas. While much of this fuel is used for farming activities like ploughing and irrigation, a significant proportion is also used by tractors providing transport. Transportation is an important function of tractors in rural China, and this fuel use is accounted for in the agricultural sector. We have made a tentative correction for the transport adjustments.

As of 1988, the total power of agricultural machinery was $266 \mathrm{GW}$, up from $150 \mathrm{GW}$ in 1980. This is evident in Figure III.44.

Tractors account for the largest percentage, with a total power of $82.2 \mathrm{GW}$. Small tractors (with an average power of about 8.9 $\mathrm{kW}$, or about $10 \mathrm{hp}$ ) provided $65 \%$ of this tractor power. Irrigation pumps are the second largest consumer, with a total power of 66 GW in 1988, of which 54\% was electric. Trucks used in agriculture have a total power of $43 \mathrm{GW}$ (with an average horsepower of 85), motorized fishing boats make up $5.5 \mathrm{GW}$, and the remaining $69 \mathrm{GW}$ is unspecified agricultural power [SSB, 1989c]. While total agricultural power grew at an annual rate of $7.6 \%$ from 1980 to 1988 , oil and electricity use in this sector grew much more slowly at $2.5 \%$ per annum. Diesel use remained almost constant throughout this period. This can be attributed in part to increasing energy efficiency, but it is also likely due largely to machinery left idle because of chronic fuel shortages in rural areas.

Despite recent improvements, energy inefficiency in agricultural machinery is still widespread. Two cases are examined here to exemplify this assertion.

Irrigation. In practice, the efficiency of irrigation pumps is $20 \%$ below their designed performance and 30\% below their modern foreign counterparts. Three contributing 
Figure III.42: Energy End Use In Agriculture by Fuel, Selected Countries, 1987.

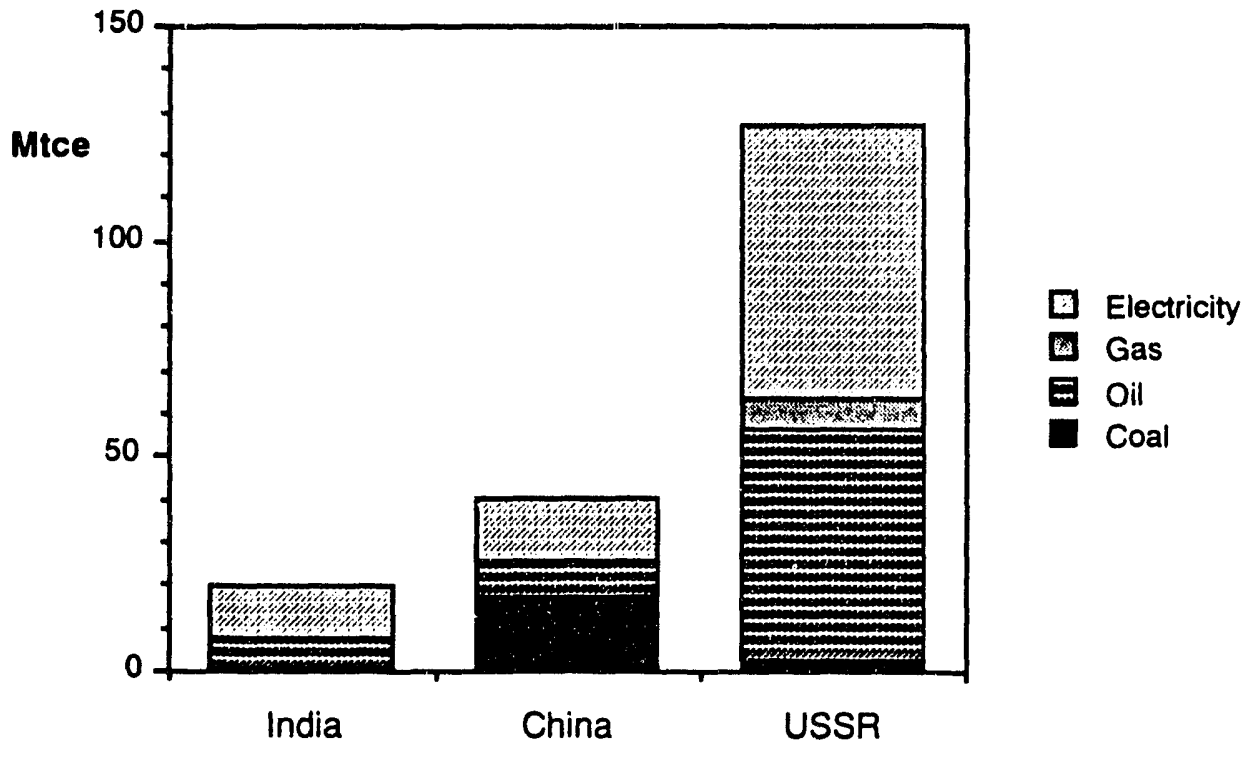

Sources: China - Energy Statistical Yearbook of China, 1989; India - International Energy Studies Database, Lawrence Berkeley Laboratory, 1991; USSR - IEA, World Energy Statistics \& Balances, 1971-1987.

Note: Energy consumption in US agriculture is not reported separately from industry.

Figure III.43: Energy End Use in Agriculture by Fuel, 1980-1988.

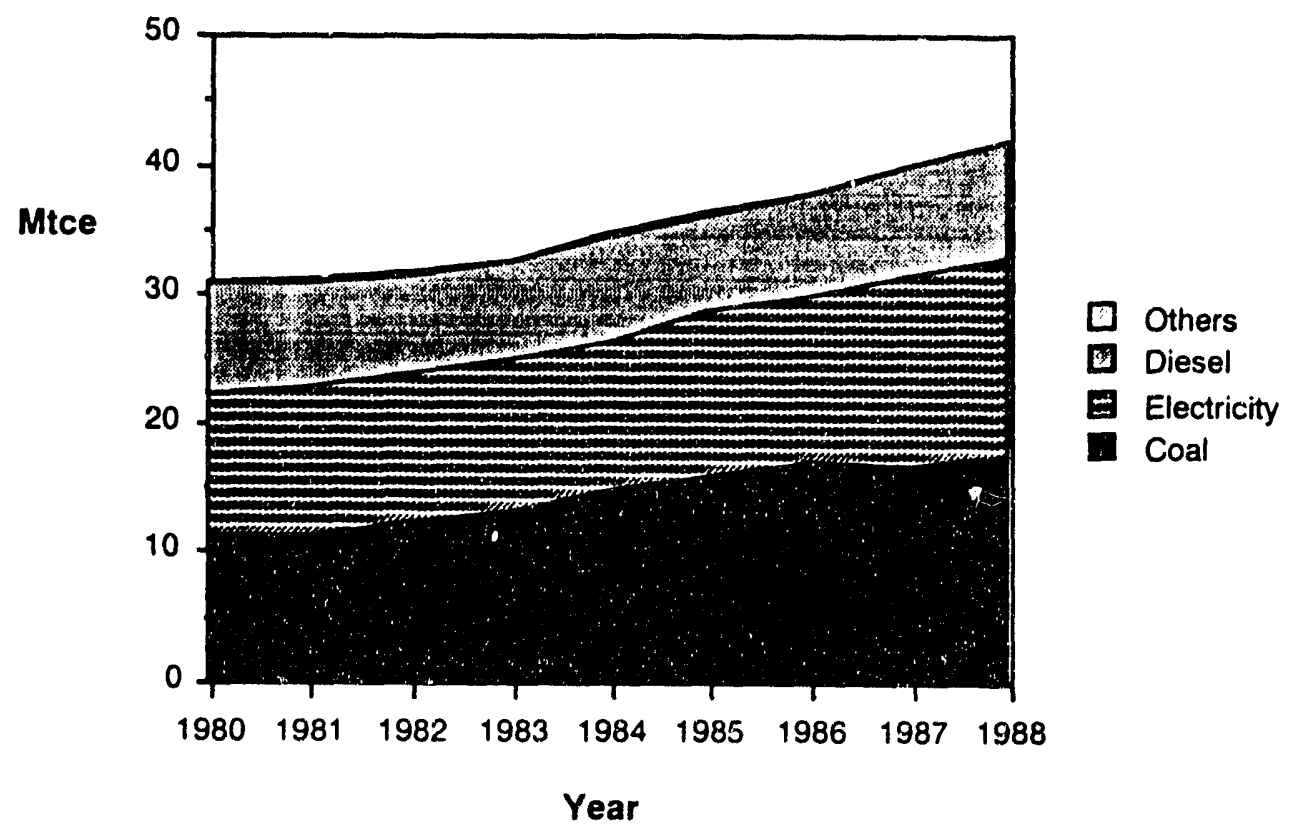

Source: Energy Statistical Yearbook of China, 1989. 
Figure III.44: Power of Agricultural Machinery by Type, 1980-1988.

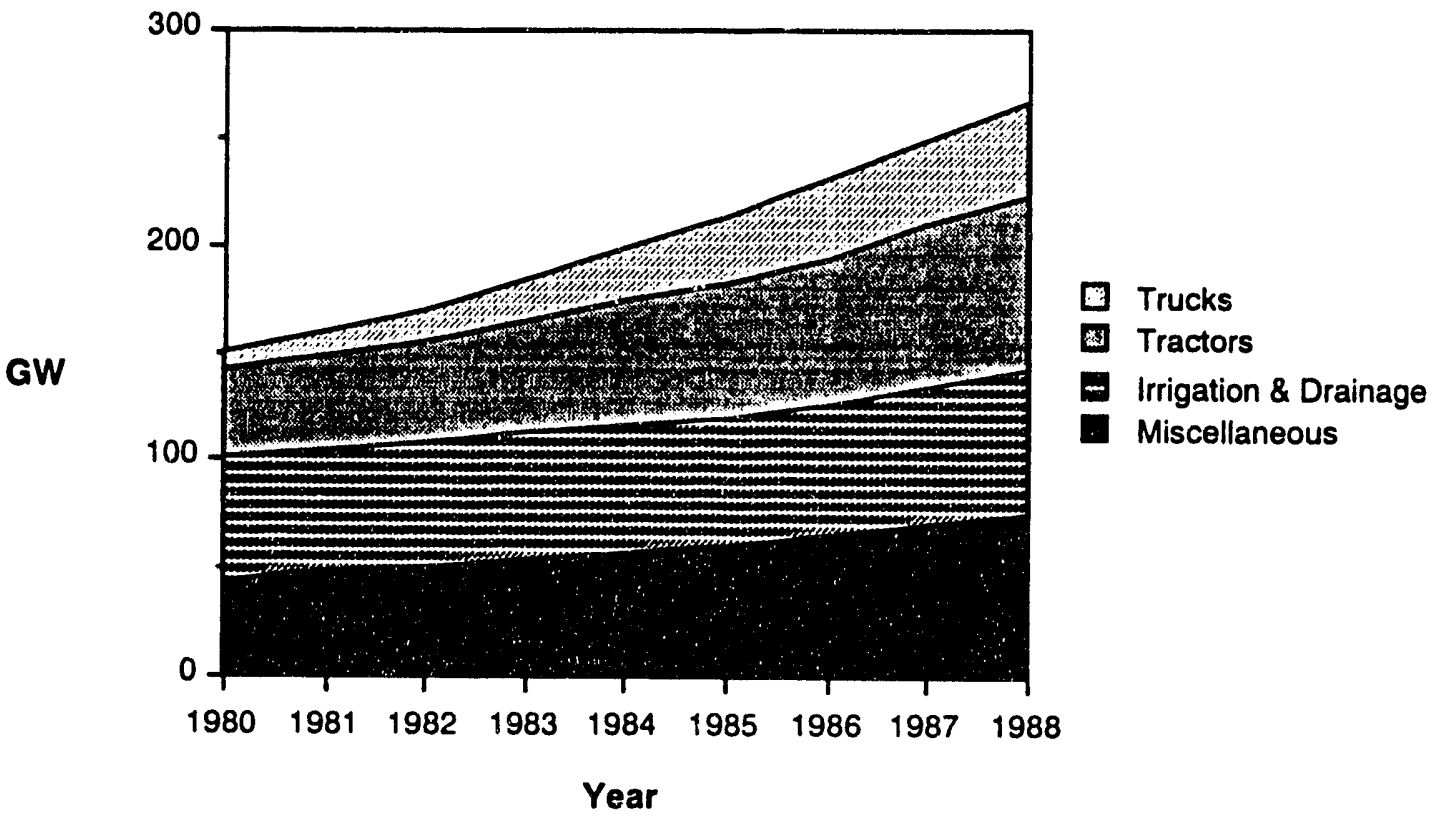

Source: Energy Statistical Yearbook of China, 1989.

factors have been identified. First, blind drilling, without consideration of site groundwater reserves, has contributed to a $50 \%$ decrease of average irrigated area per unit pump power nationwide since the 1970s. Second, poor ditch and canal quality allows for seepage and decreases the water delivered per unit energy input into irrigation. Finally, pumps are often operated at partial load because of poor matching of pump lift with required lift, which impairs efficiency. For example, $60 \%$ of the pumps in Jilin province are used mainly for water lifting below their designed lift height. Finally, like much of Chinese machinery, pump design and manufacturing technology are outdated, and obsolete pumps are still widely used [Zheng, 1988].

Tractors. There are two main groups of tractors presently operating in China. The first is made up of imitations of 1950s Soviet models, with fuel consumption 10-20 grams per horsepower-hour ( $g / h p-h)$ higher than their modern counterparts. The second is made up of domestic models based on 1960s technologies, with fuel consumption 5-10 $\mathrm{g} / \mathrm{hp}-\mathrm{h}$ higher. In 1984, the average tractor fuel consumption was 195 grams per horsepower-hour, which is about $10 \%$ higher than in industrialized countries [Ren, 1988] Poor maintenance also contributes to further worsening of fuel economy.

In China, very unlike the heavily mechanized agricultural sectors in industrialized nations, most of the farming work is still done by human and animal power. In 1988, $48 \%$ of the total cultivated area ( $96 \mathrm{Mha}$ ) was tractor plowed. Of this area, only about $15 \%$ was fully mechanized. Mechanically irrigated areas comprised 59\% of the total land area under irrigation [SSB, $1989 \mathrm{c}]$. Hence, energy input per unit of agricultural output is lower than in industrialized countries. For example, the diesel/land ratio for grain production is 41 1/ ha for China [Wen, 1987] and 51 1/ha in the US; similarly, the electricity/land ratio for grain is $126 \mathrm{kWh} / \mathrm{ha}$ in China and 236 $\mathrm{kWh} / \mathrm{ha}$ in the US. Relative to the US, labor inputs commonly are substituted for energy in Chinese farming techniques. The labor productivity of American grain production is more than 100 times higher than that of China.

While Chinese agriculture presently requires fewer energy inputs compared to its industrialized counterparts, its demand for 
chemical fertilizers is comparable. Chemical fertilizer consumption has more than doubled, while grain production has increased little since the late 1970s. Fertilizer consumption is almost the same in China and America [Yearbook of the World Economy, 1988]. In grain production, China uses more nitrogen but less phosphate and potash. Because of the limited domestic supply, $20 \%$ of fertilizer consumption must be imported [SSB, 1989c]. High demand for fertilizers will require more energy inputs in the chemical sector. Thus the agriculture sector consumes energy indirectly. The magnitude of this fossil fuel subsidy is illustrated in Figure III.45.

Energy consumption attributable to agriculture roughly doubles when energy used in manufacturing fertilizer is counted. This indirect energy subsidy is, in part, what has allowed direct energy intensity in agriculture to have decreased recently.
It is also interesting to note that burning of crop residues requires an additional $6 \mathrm{Mtce}$ of fertilizer inputs to replace nitrogen that would probably have otherwise returned to the soil. Crop residues, however, provide over 200 Mtce of direct energy for cooking and heating, so this indirect loss has only about a $3 \%$ effect.

In summary, as more and more farmers leave the fields, switching to non-agricultural occupations and often migrating to cities, energy-using equipment will be substituted for labor and the energy intensity of agriculture will increase. This trend is already evident. Increasing use of chemical fertilizers and pesticides in recent years has helped to relieve Chinese farmers from the intensive labor requirements of organic farming, but has increased the (indirect) energy intensity of farming. Further mechanization of agriculture will continue this trend.

Figure III.45: Energy End Use in Agriculture, Including Fertilizer, 1980-1988.

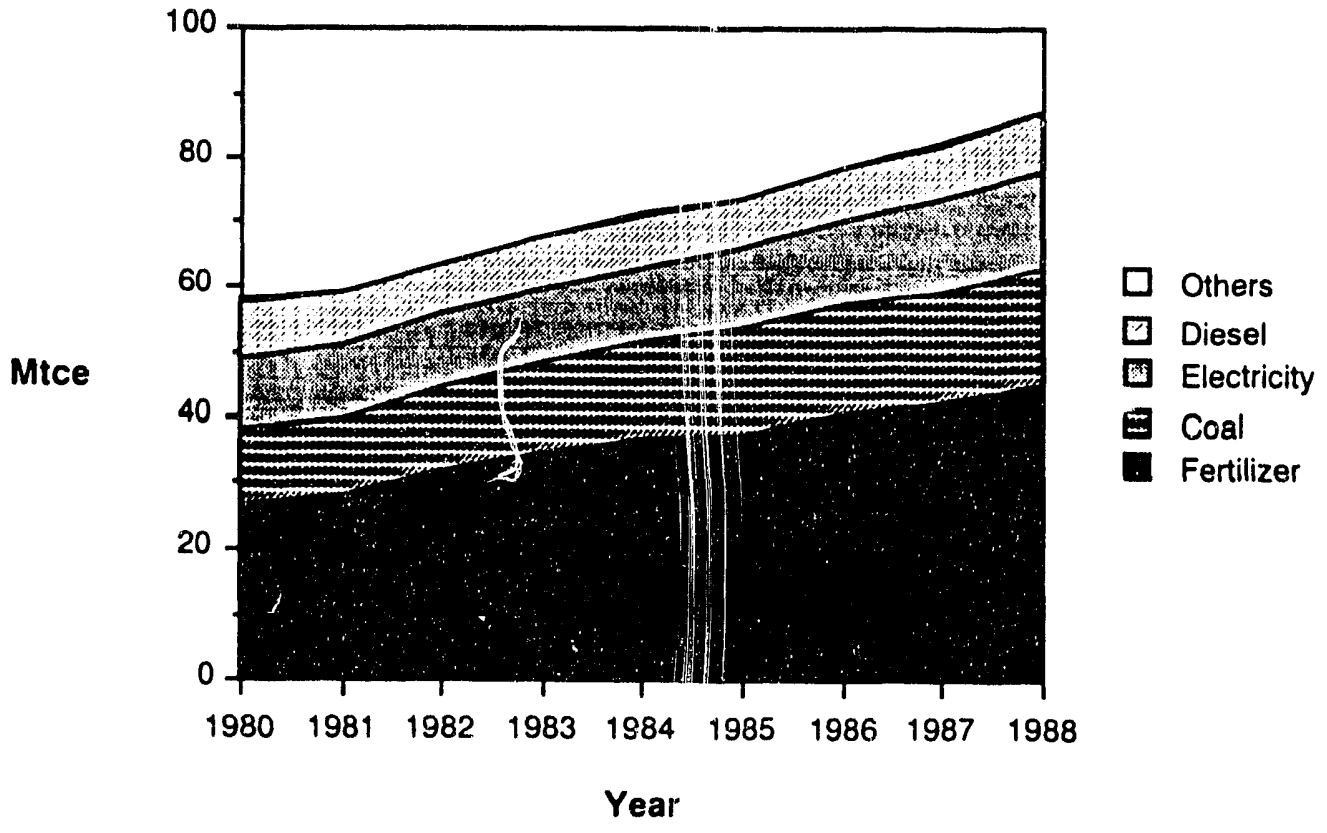

Source: Statistical Yearbook of China, 1989.

Note: Fertilizer composition in 1988 was $66 \%$ nitrogenous, $18 \%$ phosphate, $5 \%$ potash, and $11 \%$ complex fertilizers. Totals are in terms of effective components $(N, P, K)$. These shares are assumed constant over the entire period. Embodied energy in fertilizers is assumed to be 80, 15, and $5 \mathrm{MJ}$ per $\mathrm{kg}$ of $N, P$. and $K$ respectively. The weighted average (assuming complex fertilizers are in the same ratio as the individual components) is $62 \mathrm{MJ} / \mathrm{kg}$, or 2.1 Mtce per Mton. 


\section{References}

The British Petroleum Company, B P Statistical Review of World Energy, (The British Petroleum Company: 1990).

Qiu Daxiong, et. al., Energy Analysis of Five Industrial Sectors (in Chinese), Energy Future and New Energy Conservation Technologies, conference proceedings (Beijing: Academic Journal Press, 1988).

Energy Information Agency, US Department of Energy, Annual Energy Review, (Washington DC: 1990).

Li Jinwen et al, Handbook of China's Transportation (in Chinese), (Beijing: Economic Science Press, 1989).

Government of the People's Republic of China and Academica Sinica, Sectoral Energy Demand in China, RAS/86/136, (United Nations Regional Energy Development Programme: November, 1989).

Haugland, Torleif and Kjell Roland, Energy, Environment and Development in China, (ISBN: 82-90156-89-8) (The Fridtjof Nansen Institute: 1990).

Huang, Y. J., et al., Energy Efficiency in Chinese Apartment Buildings: Parametric Runs with the DOE.2 Computer Program, LBL-15183, 1982.

International Energy Agency (IEA), World Energy Statistics and Balances, 1971-1987, 1989.

International Energy Agency, Energy Balances of OECD Countries, 1987, 1988, 1990.

Jiang Zhengping, Energy Analysis of Building-Materials Production in China (in Chinese), Research Report, Energy Research Institute (Beijing: 1988).

Jiang Zhengping, "Urban Energy Consumption in China," (in Chinese), Selected Articles on Urban Energy Use in China, Committee on
Urban Energy, China Energy Research Society, (Beijing: 1991).

Lang Siwei, "Energy Use in Chinese Buildings," Proceedings of the ChineseAmerican Symposium on Energy Markets and the Future of Energy Demand, LBL-26260, 1988.

Levine, Mark and Liu Xueyi, Energy Conservation Programs in the People's Republic of China, Lawrence Berkeley Laboratory (LBL-29211), August 1990.

Liang Baofen, et al, "Efficient Stove and Energy Conservation," (in Chinese) Proceedings, Energy Future and New Conservation Technologies, (Beijing: Academic Journals Press, 1988)..

Liu Ziping and Qin Shiping, "Assessment of Capital Construction and Technical Renovation Projects of Energy Conservation Investment," (in Chinese) Selected Articles on Energy Conservation in the Sixth FiveYear Plan, Energy Press, (Beijing: 1989).

Metallurgical Industry Press, Yearbook of China's Steel Industry (in Chinese), (Beijing: $1988,1989,1990)$.

Meyers, S. and G. Leach, Biomass Fuels in the Developing Countries: An Overview, LBL27222, 1989.

Ministry of Energy, Energy in China, (Beijing: 1989).

Qin Shiping and Xin Dingguo, Analysis of Technical Renovation Projects of Energy Conservation Investment (in Chinese), (Beijing: Energy Press, 1989).

Ren Wenhui et al, "Energy Conservation Potential in Agricultural Machinery," (in Chinese) Proceedings, The Third National Conference on I ural Energy, (Beijing: 1988).

Ross, Marc and Liu Feng, The Energy Efficiency of the Steel Industry of China, Energy, Vol. 16, No.5, pp. 833-848, 1991. 
State Planning Commission of China, National Rural Energy Planning (in Chinese), (Beijing: Standards Press, 1990).

State Statistical Bureau of China, The Development of China's Transportation and Telecommunications (in Chinese), (Beijing: China Statistics Press, 1989).

State Statistical Bureau of China, Energy Statistics Yearbook of China (in Chinese), (Beijing: 1989).

State Statistical Bureau of China, Statistical Yearbook of China, (Beijing: 1988, 1989, 1990, 1991).

State Statistical Bureau of China, Statistical Yearbook of China's Industrial Economy, (Beijing: 1988, 1990).

State Statistical Bureau of China, Yearbook of China's Coal Industry, (Beijing: 1987).

State Statistical Bureau of China, Yearbook of China's Transportation, (Beijing: 1987).

State Statistical Bureau of China, 1988 Urban Household Income and Expenditure Survey Data, (Beijing: 1989).

State Price Bureau of China (SPB), Price Yearbook of China, 1989 (in Chinese), (Beijing: Price Press, 1990).

Department of Materials, Fuel Distribution in China (in Chinese), (Harbin University of Industrial Technology Press, 1988).

Meyers, S. et al, Energy Efficiency and Household Electric Appliances in Developing and Newly Industrialized Countries, Research Report, LBL-29678, Lawrence Berkeley Laboratory, Berkeley, 1990

Schipper, L. and C. Cooper, "Energy Use and Conservation in the USSR," pending publication in Energy, the International lournal.

Tata Energy Research Institute, TERI Energy Data Directory and Yearbook (New Delhi, 1988).
United Nations Rural Energy Development Program, Sectoral Analysis of Energy Demand in China, (Beijing: Energy Press, 1989.)

Venkateswaran, S. R., and H. E. Lowitt, The U.S. Cement Industry: An Energy Perspective, DOE/RL/01830-T58, May 1988.

Wang Qingyi, Energy in China, (in Chinese), (Beijing: Metallurgical Industry Publishing House, 1988).

Wen Dazhong, On China's Petro-Agriculture, Energy Journal (in Chinese), Beijing, No. 6, 1987.

World Bank, China: The Energy Sector, (Washington D.C., 1985).

World Bank, China, Socialist Economic Development, Volume I: The Economy, Statistical System, and Basic Data, (Washington D.C., 1983).

World Bank, China: Macroeconomic Stability and Industrial Growth under Decentralized Socialism, (Washington D.C., 1990).

Wu Xiaoling, The Current Status of Oil Consumption in Agricultural Production and Its Policy Implications (in Chinese), Proceedings, The Third National Conference on Rural Energy, (Beijing, Academic Journal Press, 1988).

Xia Meixiu, "Electricity Pricing and Its Crisis," Energy Journal, (Beijing, No. 1, 1989).

Yang Hongnian, "Energy and Transport in China," Proceedings of the ChineseAmerican Symposium on Energy Markets and the Future of Energy Demand, LBL-26260, 1988.

Yearbook of the World Economy, (in Chinese), (Beijing: 1988).

Zhang Zehou, The Present Status of Industrial Equipment in China and Problems in China (in Chinese), (Shanxi People's Press, 1984). 
Zheng Xiaoying, "Energy Analysis of China's Irrigation System," (in Chinese) Proceedings, The Third National Conference on Rural Energy, (Beijing 1988).

Zhou Fengqi et al., Sectoral Energy Demand in China (in Chinese), (Beijing: Energy Press, 1989). 
Appendix 1

\section{ENERGY UNITS AND CONVERSIONS}

\begin{tabular}{lll}
\hline & Heat & \\
Fuel & content (low) & $\begin{array}{l}\text { Multiplier } \\
\text { (to tce) }\end{array}$ \\
(in tons unless otherwise stated) & (G) & 1 \\
\hline Standard coal & 29.3 & 0.71 \\
Chinese average raw coal & 20.9 & 0.90 \\
Chinese average washed coal & 26.4 & $0.68-1.13$ \\
Bituminous coals & $20-33$ & $0.27-0.68$ \\
Brown coals, lignites & $8-20$ & 0.97 \\
" Coke & 28.5 & 1.43 \\
Chinese average crude oil & 41.9 & 0.19 \\
Chinese average crude oil (bbl) & 5.6 & 1.53 \\
Standard crude oil & 44.9 & 0.21 \\
Standard crude oil (bbl) & 6.1 & 1.43 \\
" Fuel Oil & 41.9 & 1.33 \\
Chinese average natural gas (kcm) & 39.0 & 1.32 \\
Standard natural gas (kcm) & 38.7 & 1.57 \\
* Refinery dry gas & 46.1 & 0.61 \\
" Coke oven gas (kcm) & 18.0 & 0.51 \\
* Town gas (kcm) & 15.1 & 1.47 \\
" Gasoline & 43.1 & 1.47 \\
" Kerosene & 43.1 & 1.46 \\
" Diesel & 42.7 & 1.71 \\
* LPG & 50.2 & 0.404 \\
Electricity (1000 kWh) & & $0.48-0.58$ \\
Fuelwoods, air-dry (ton) & $14-17$ & $0.41-0.55$ \\
Crop residues, air dry (ton) & $12-16$ & $0.38-0.48$ \\
Dried dung (ton) & $11-14$ & $0.26-0.36$ \\
Peat (ton) & $7.5-10.5$ &
\end{tabular}

Note: All units in this report are in metric.

Sources: Rows that start with "Chinese" or * are from Yearbook of Chinese Energy Statistics, 1990. The rest are from Smil, Energy in China's Modernization, 1988. Where the figures differed, YCES figures were used. 

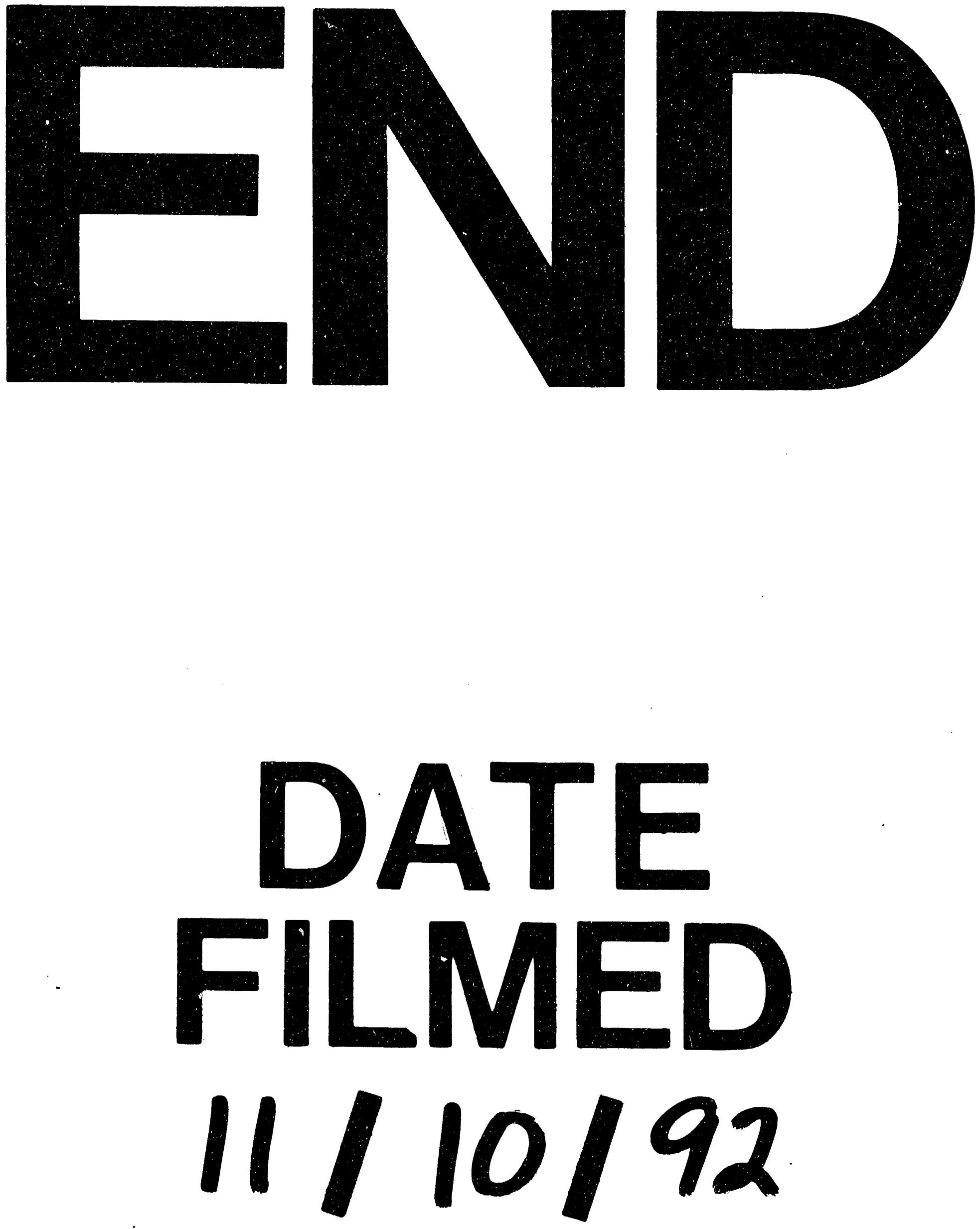

1 
